
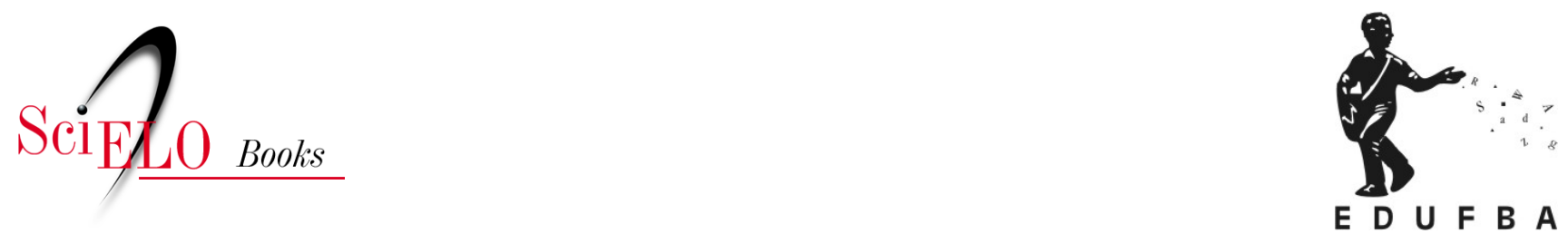

\title{
A luz e a cena não realista
}

\author{
Eduardo Tudella
}

\section{SciELO Books / SciELO Livros / SciELO Libros}

TUDELLA, E. A luz e a cena não realista. In: A luz na gênese do espetáculo [online]. Salvador: EDUFBA, 2017, pp. 411-515. ISBN: 978-85-232-1858-4.

https://doi.org/10.7476/9788523218584.0014.

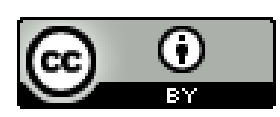

All the contents of this work, except where otherwise noted, is licensed under a Creative Commons Attribution $\underline{4.0 \text { International license. }}$

Todo o conteúdo deste trabalho, exceto quando houver ressalva, é publicado sob a licença Creative Commons Atribição 4.0.

Todo el contenido de esta obra, excepto donde se indique lo contrario, está bajo licencia de la licencia Creative Commons Reconocimento 4.0. 


\section{A LUZ E A CENA NÃO REALISTA}

A expressão "não realista" (que pode ser relacionada ao teatro "não mais dramático", mencionado abaixo) é aqui aplicada com o intuito de ampliar o espectro das escolhas para este último capítulo cujo princípio orientador está nas referências à visualidade, presentes em manifestações cênicas que começaram a aparecer no final do século XIX, continuaram no século XX, e se mantêm ativas até hoje. Os artistas e/ou teóricos aqui mencionados ocupam tal espaço devido às suas relações com a natureza visual do acontecimento espetacular. Durante os estudos que antecederam essas escolhas foi significativa a provocação de determinados autores, pensadores e/ou artistas, listados a seguir: Hans-Thies Lehmann, O teatro pós-dramático (Postdramatisches theater); Sarah Kane (1971-1999), 4:48 Psicose (4.48 - psychosis); Berthold Brecht (1898-1956), o poema A iluminação (Die beleuchtung); Louie Fuller (1862-1928); Samuel Beckett (1906-1989), a peça Comédia (Play); e Adolphe Appia, A música e $a$ arte do teatro (Music and the art of the theatre). 


\section{HANS-THIES LEHMANN E A REQUALIFICAÇÃO DA PALAVRA NO TEATRO}

Desde sua publicação original em 1999, O Teatro pós-dramático de Lehmann causou muita discussão no nível internacional, sendo traduzido para vários idiomas, desde francês e japonês, em 2002, seguindo-se esloveno (2003), persa (2005), repercutindo ruidosamente na universidade e na práxis cênica brasileira desde sua publicação em português, em 2007. Parecia haver surgido um manifesto, um documento definitivo de apoio - ou uma oportuna poética de programação e provocação, incorporada rapidamente por artistas e teóricos.

O reconhecimento da desconstrução da personagem dramática havia se tornado realidade. Abrindo a tradução inglesa, Karen Jürs-Munby (2006, p. 1, tradução nossa) resume a questão:

O estudo de Hans-Thies Lehmann obviamente respondeu à vital necessidade de uma acessível e compreensível teoria articuladora das relações entre as formas de teatro 'não mais dramáticas' que emergiram desde os anos de 1970. ${ }^{1}$

Essa tradução, que mereceu elogios do próprio autor, foi usada no trabalho em curso. A primeira observação de Lehmann que desperta a atenção aparece logo no prefácio dessa edição anglo-americana. Ressaltando que seu interesse não está no texto e, sim, nos meios da realização teatral, ele mencionou a tensão entre o teatro dramático e o que ele denominava novo teatro, ou pós-dramático, citando a obra 4.48 psychosis, da autora inglesa Sarah Kane, cuja estreia se deu em 23 de junho de 2000, pouco mais de um ano depois de sua morte, em fevereiro de 1999. A declarada intenção de Lehmann privilegia na sua teoria a atenção ao acontecimento cênico em detrimento do texto que o antecede, e, por outro lado, reconhece a importância de Sarah Kane como autora que, de acordo com seu próprio juízo, produziu um dos mais importantes textos relacionados ao teatro pós-dramático. Suas observações geraram um consistente material para o presente trabalho, uma vez que permitiram uma espécie de elo entre teoria, dramaturgia e práxis cênica.

As inquietações sobre o papel do texto na cena pós-dramática e a desconstrução da palavra falada como um dos elementos da ação (de uma personagem) fortalecem a necessidade de algo que, na cena, seja visto (do já repetido verbo grego théa). Isso aponta para uma interpretação radical dos gregos antigos no que se refere à acentuação da natureza visual do teatro, já na sua própria denominação,

\footnotetext{
1 “Hans-Thies Lehmann's study has obviously answered a vital need for a comprehensive and accessible theory articulating the relationship between drama and the 'no longer dramatic' forms of theatre that have emerged since the 1970s."
} 
como já se repetiu exaustivamente. A mais notável abordagem do teatro grego, que apareceria no trabalho de Aristóteles, repercutiu de tal modo entre os estudiosos ao longo da modernidade, a ponto de tornar a tragédia grega academicamente conhecida como "aristotélica". No entanto, a fala poética incluída na manifestação denominada "teatro" pelos gregos, a importância das palavras ouvidas na tragédia "greco-aristotélica", nos diálogos construídos sob o prisma de conflitos originados em desejos profundos das personagens - tema determinante na compreensão de Aristóteles para a tragédia - finalmente havia desaparecido sob o teatro pós-dramático.

De todo modo, o grau de heterogeneidade no espectro do pensamento pós-dramático e das manifestações por ele validadas leva a uma derivação estética, comentada na tradução norte-americana: “[...] a noção de teatro pós-dramático e sua valorização da dimensão da performance, não implica que textos escritos para o teatro deixem de ser relevantes ou não possam ser considerados nesse contexto". 2(JÜRS-MUNBY, 2006, p. 6, grifo e traducão nossos) Tal assertiva pode parecer mero atrelamento a uma tradição condenada pelas "vanguardas" do século XX; no entanto, ela pode também incluir certa sagacidade estratégica da estética em questão. Afinal, a práxis cênica questionou, modificou e subverteu o texto dramático ao longo da história sem, no entanto, desconsiderar seu papel decisivo em importantes momentos do teatro.

Por outro lado, o anseio pelo questionamento do modelo "aristotélico" dá lugar a iniciativas como aquela mencionada por Tim Etchells, diretor da companhia britânica Entretenimento forçado (Forced entertainment): "A peça trata da ação física e da construção do cenário como modos de escrita, [a peça] fala das palavras escritas que serão vistas e lidas no palco, ao contrário de serem faladas [...]".3 (ETCHELLS apud JÜRS-MUNBY, 2006, p. 9) A resposta a tal anseio, o desejo de desconstruir o diálogo originado na iniciativa grega, incorpora profundamente, então, a visibilidade, no diversificado modelo pós-dramático que assume uma espécie de interpretação radical da ideia grega de cena. Quero dizer, desconsiderando o diálogo falado, resta no pós-dramático - como legado do teatro concebido pelo pensamento grego - o que está latente no substantivo nomeador do próprio teatro, ou seja, a acentuação da cena como algo que se vê. As considerações preliminares da tradução, das quais aspectos chave serão mencionados a seguir, representam excelente esforço para introduzir o leitor no novo teatro vislumbrado por Lehmann.

\footnotetext{
2 "the notion of postdramatic theatre and its valorization of the performance dimension does not imply that texts written for the theatre are no longer relevant or cannot be considered in this context."

3 "The piece talks about physical action and set construction as forms of writing, it talks about writing words to be seen and read on-stage rather than spoken, [...]."
} 
No teatro pós-dramático o texto devia apresentar uma "teatralidade" latente, que o afastasse da representação dramática de um cosmos ficcional fechado e da mimética de uma fábula. Separado do drama na segunda metade do século XX o novo teatro trouxe a imposição da materialidade da cena e a destruição da hegemonia do texto (dramático). A linguagem buscada pelo que Lehmann denominou novo teatro e também teatro pós-dramático exigia nova postura que incorporasse diversificados instrumentos, acessórios e controle, com o objetivo de promover excelência visual. Portanto, mesmo no enfrentamento entre o novo teatro e o drama, restava ainda um traço que os unia, o binômio visualidade-visibilidade.

O texto deveria ser transformado em mais um elemento da scenography (grafia da cena/escrita cênica/escritura cênica), mostrado por vezes em imagens reproduzidas através de diversificados media de áudio e vídeo. O espectador era chamado a atuar como cocriador do texto (espetáculo), o que implica numa transtextualidade, num processo de reciclar, reusar e refazer, livre de normas, analogamente ligado por Jürs-Munby, ao palimpsesto. ${ }^{4}$ É importante ressaltar o ataque à noção aristotélica de equilíbrio e totalidade do drama que apresenta extensão e duração apropriadas para sua apreensão lógica, administrável, como espelho de um mundo passível de ser apreendido integralmente.

Comentadores do teatro pós-dramático consideram que ele se relacionava com a descrença no controle, fundamentando-se no que caracterizava como seu escorregadio cotidiano contemporâneo revolvido por entranhas tecnológicas. Segundo Jürs-Munby (2006, p. 12), o mundo deixara de ser a totalidade ficcional enclausurada pela quarta-parede como acreditavam Antoine e Strindberg. O performer não representava uma personagem, ele estava lá. Não se tratava de ficção; uma ação acontecia, naquele instante e lugar definidos para a performance, como numa celebração. Talvez seja possível dizer que o desejo da ação pós-dramática era ser a ação verdadeira, viva, presente, ou "real" (?!). Outro "naturalismo" ou o naturalismo elevado a uma instância radical. Tivesse vivido nos tempos pós-dramáticos Zola aplaudiria: tratava-se de incorporar pressupostos artísticos à investigação do ser humano. Arte e ciência compartilhando espaço e tempo, sugerindo um ritual.

Ao traçar um panorama de sua abordagem da cena na segunda metade do século XX, na qual ele encontrou o pós-dramático, o próprio Lehmann voltou à noção de totalidade. É importante dizer que, compreendida como totalidade teatral e não prioritariamente dramática, caracterizando a cena como uma espécie de "texto total". Isso, ainda segundo ele, reduz o valor do texto dramático, levando-o a assumir o papel de mais um aspecto da cena, em companhia dos aspectos visuais e sonoros;

4 Papiro ou pergaminho, cujo texto primitivo foi raspado, para dar lugar a outro. (HOUAISS, 2009) 
quiçá tácteis e olfativos. Eliminando-se a célebre hegemonia (do drama) abriu-se espaço para uma parceria que exigia flexibilidade do texto, uma vez que ele deixava de representar a fala de personagens - se é que ainda se poderia encontrá-las - assumindo uma "teatralidade" autônoma.

Essa nova função da palavra destruía as figuras (personagens) de pretensa profundidade que, no antigo teatro "dramático", falavam. Mergulhado no universo da visão, Lehmann (2006, p. 18, tradução nossa) fez uma declaração prenhe de pistas dos profundos compromissos do seu novo teatro: “[...] ao invés da ilusão de um espaço tridimensional, 'leva-se ao palco' uma imagem sem planos, sua realidade bidimensional e a realidade da cor como uma qualidade autônoma [...]". ${ }^{5}$ Ao confrontar a ilusão de tridimensionalidade com essa nova cena bidimensional, ele indica relações entre cena e pintura, mergulhando na visualidade.

Via-se uma manifestação que incorporava a multiplicidade de camadas produzidas por um conjunto de artistas, incluindo a tecnologia dos media (eletro-eletrônico-digitais), mas, que mantinha um momento e lugar de encontro no qual a vida "real" tocava a vida poética e esteticamente organizada. Então, para Lehmann, o que ele descrevia como teatro pós-dramático era um novo tipo "multiformal" de discurso teatral, provocado pela divulgação e pela onipresença dos media no cotidiano. Sendo, também, meditação autorreflexiva que incorporava ritmo, tom e silêncio - acentuando sua qualidade musical - o teatro efetivava gestualidade e formas grotescas, por vezes, em espaços "vazios". Encontrar-se-ia, portanto, nessas considerações, uma profunda radicalização da práxis cênica pós-dramática como assertiva visual.

Em abordagens de questões mais especificamente ligadas ao tratamento do espaço, Lehmann deixou para o leitor ou estudioso do seu (novo) teatro uma vigorosa articulação visual. Uma das suas mais importantes indicações encontra-se no prólogo, quando ele diz:

Ainda que possamos discutir o grau, e de que maneira as plateias dos séculos que nos antecederam foram sensibilizadas pelas 'ilusões' criadas pelos truques de palco, pela luz ardilosa, fundo musical, figurinos e cenários, pode-se afirmar que o teatro dramático era a ordem da ilusão. ${ }^{6}$ (LEHMANN, 2006, p. 22, tradução nossa)

\footnotetext{
5 "instead of the illusion of three-dimensional space, what is being 'staged' is the picture's plane-ness, its two-dimensional reality, and the reality of colour as an autonomous quality."

6 "Although it remains debatable to what degree and in what way the audiences of former centuries were taken in by the 'illusions' offered by stage tricks, artful lighting, musical background, costumes and set, it can be stated that dramatic theatre was the formation of illusion."
} 
Seguindo o raciocínio que constrói essa afirmação é possível sublinhar a decisiva função da imagem visual na ilusão à qual ele se refere, uma vez que o teatro precisava - e dependia - da luz para mostrar todo o aparato criado no palco e, desse modo, "iludir" visualmente o espectador. O que não mudou, completamente, até hoje. E mais que isso, a luz fica cada vez mais ardilosa através da incorporação de tecnologias podendo até incorporar outras possíveis traduções do termo artful (que aparece na tradução de Jürs-Munby mencionada neste livro) e revelar-se "esperta", "astuciosa" e, quem sabe até, com mais uma possibilidade radical de tradução: um truque velhaco. Portanto, quando se levam em conta os compromissos visuais que o teatro pós-dramático assumiu toda a cautela será bem-vinda ao trabalho do iluminador que ainda hoje se interesse pelas propostas de Lehmann. Sem cautela o iluminador acabará repetindo as trapaças que ele parecia condenar.

Mesmo os compromissos mais primitivos com a luz estão registrados na linguagem usada por Lehman (2006, p. 26, tradução nossa) no seu texto:

Em relação aos novos textos teatrais, os estudiosos têm falado sobre 'textos teatrais não mais dramáticos', como já mencionei, mas, o que ainda está por se fazer é uma tentativa de investigar o novo teatro e a diversidade dos seus meios teatrais mais detalhadamente sob a luz da estética pós-dramática. ${ }^{7}$

Como se pode ver no exemplo acima, ele aplica o termo "luz" para se referir ao ideário do teatro pós-dramático. Além disso, Lehmann comprova e estreita sua confiança na contribuição da luz, em momentos particulares, ainda que, ao discutir a Poética de Aristóteles, ele faça uma importante ressalva:

[...] Aristóteles volta-se para o filosófico, na tragédia. Ele vê a mimesis como uma espécie de 'mathesis', um aprendizado que se torna mais agradável através da alegria do reconhecimento dos objetos da mimesis - um prazer necessário apenas para as massas, não realmente para o filósofo [...]. ${ }^{8}$

Como o público não é composto exclusivamente por filósofos, o teatro decidiu incorporar a importância da imagem (o reconhecimento dos objetos), tornando-a indispensável em sua constituição. Citando o próprio Aristóteles, Lehmann

\footnotetext{
7 'With respect to newer theatre texts, scholars have talked about 'no longe dramatic theatre texts', as already mentioned, but what is still missing is an attempt to survey the new theatre and the diversity of its theatrical means in more detail in the light of postdramatic aesthetics."

8 "[...] Aristotle is concerned with the philosophical in tragedy. He regards mimesis as a kind of 'mathesis', a learning that becomes more pleasurable through the enjoyment of recognizing the object of mimesis - a pleasure only needed by the masses, not actually by the philosopher."
} 
(2006) apresenta o que pode ser considerado um importante argumento para a definição de critérios de aplicação da luz à práxis cênica:

Compreender é extremamente agradável, não apenas para filósofos, mas, do mesmo modo, também para outros, apesar da sua capacidade limitada para isso. Essa é a razão porque as pessoas têm prazer em ver imagens; o que acontece é que, vendo as imagens elas passam a entender e descobrem o que cada coisa é [...]. ${ }^{9}$ (ARISTÓTELES apud LEHMANN, 2006, p. 40, tradução nossa)

Ao fim e ao cabo, Aristóteles parecia ter razão. Se não é possível avaliar precisamente a relação dos homens daquele seu tempo com a imagem, hoje, ao menos, testemunha-se o papel dessa mesma imagem na construção da cultura, registrado pelo próprio Lehmann (2006) ao longo do seu livro. No discurso em torno das primeiras manifestações históricas das vanguardas modernas, ele cita Michael Kirby, descrevendo, sucintamente, o teatro dos simbolistas:

A estética simbolista demonstra um voltar-se para dentro, longe do mundo burguês e dos seus padrões, para um mundo mais privado, pessoal, e extraordinário. O espetáculo simbolista ocorria em pequenos teatros. Era deslocado, distante e estático, envolvendo reduzida energia física. A iluminação era frequentemente de reduzida intensidade. Os atores trabalharam, muitas vezes, por trás de telas... A arte era autossuficiente, isolada, completa em si mesma. Podemos chamar este o modelo 'hermético' de espetáculo da vanguarda. ${ }^{10}$ (KIRBY apud LEHMANN, 2006, p. 57, tradução nossa)

Uma imaginação treinada e familiarizada com as iconografias teatrais do século XIX vislumbraria a qualidade visual inscrita, ou, desejada pelo teatro pós-dramático, e registraria ainda que o uso da tela e da penumbra não seriam, necessariamente, novidades simbolistas. Desde suas primeiras incursões, portanto, as chamadas vanguardas que eclodiram no século XIX tratavam a luz como um aspecto integrado e de contribuição indispensável. Apresentando marcas radicais

9 "[U]nderstanding is extremely pleasant, not just for philosophers but for others too in the same way, despite their limited capacity for it. This is the reason why people take delight in seeing images; what happens is that as they view them they come to understand and work out what each thing is."

10 "Symbolist aesthetics demonstrate a turning inward, away from the bourgeois world and its standards, to a more personal private, and extraordinary world. Symbolist performance was done in small theatres. It was detached, distant, and static, involving little physical energy. The lighting was often dim. The actors often worked behind scrims... The art was self-contained, isolated, complete in itself. We can call this the 'hermetic' model of avant-garde performance." 
daquilo que Lehmann compreende como pré-história das vanguardas, o simbolismo trazia em sua proposição estética, aprofundamentos de compromissos particulares com a visualidade:

Com isso, a dissolução da tradicional amálgama de texto e palco tornou-se possível, além da possibilidade de uma nova maneira de reconectá-los. Olhando o texto teatral com uma dimensão poética independente e, simultaneamente, considerando a 'poesia' do palco, desacoplada do texto, como uma poesia atmosférica de espaço e luz, uma nova disposição teatral se tornou possível. ${ }^{11}$ (LEHMANN, 2006, p. 59, tradução nossa)

Num certo sentido, ao assinalar a contribuição da luz para as novas realidades cênicas dessa "poesia atmosférica de espaço e luz", Lehmann questionou a crítica que relacionava a atmosfera à luz realista. O pós-dramático afirmava-se pela elaboração independente da poética do espaço teatral exigindo contribuições estéticas muito particulares da imagem visual.

Vale comentar aqui o simbolismo de Maurice Maëterlinck (1862-1949), assim como seu "teatro estático" (drame statique) que apontam numa direção muito relevante para o presente estudo, indicando o tratamento da práxis cênica como corporificação da imagem. Aquela imagem que se projeta numa instância diversa do contexto dos media eletro-eletrônico-digitais da atualidade aproximando-se das imagens primevas, presentes na ancestralidade espetacular que antecede o teatro.

Pode-se dizer que Maëterlinck foi um autor atípico, incomum, tendo recebido o Prêmio Nobel de Literatura, em 1911, cuja justificativa oficial declara:

[...] como reconhecimento das suas multifacetadas atividades literárias, e especialmente de suas obras dramáticas, que se distinguem por uma riqueza de imaginação e por uma fantasia poética que revelam, por vezes, sob a aparência de um conto de fadas, uma inspiração profunda, e de uma maneira misteriosa elas apelam para os próprios sentimentos dos leitores e estimulam sua imaginação. ${ }^{12}$ (THE NOBEL..., 2012)

\footnotetext{
11 "With that, the dissolution of the traditional amalgamation of text and stage has become thinkable, but also the possibility of their reconnection in a new way. By regarding the theatre text as an independent poetic dimension and simultaneously considering the 'poetry' of the stage uncoupled from the text as an independent atmospheric poetry of space and light, a new theatrical disposition becomes possible."

12 " [...] in appreciation of his many-sided literary activities, and especially of his dramatic works, which are distinguished by a wealth of imagination and by a poetic fancy, which reveals, sometimes in the guise of a fairy tale, a deep inspiration, while in a mysterious way they appeal to the readers' own feelings and stimulate their imaginations."
} 
O tratamento da cena oferecido por Maëterlinck impressionou Peter Szondi (1983) que o considerou responsável por um novo rumo do drama. Szondi menciona a rubrica de abertura de Os cegos [Les aveugles, (1890)] na qual o dramaturgo "pinta" aquela que pode ser considerada a imagem "zero" da obra, uma espécie de suspensão imagética onde se introduz a visualidade inscrita numa peça. A extensão da imagem criada por Maëterlinck, da qual Szondi menciona fragmentos, está repleta de provocações que se referem à luz:

Uma floresta do norte, muito antiga, de aparência eterna, sob um céu brilhantemente estrelado. No centro, e diante do mais profundo da noite está sentado um padre muito velho, envolto em um grande manto preto. Seu dorso e cabeça, ligeiramente voltados para cima e mortalmente imóveis apoiam-se sobre o tronco de um enorme e cavernoso carvalho. O rosto é de uma lividez imutável de cera, onde se entreabrem lábios roxos. Olhos mudos e fixos não olham mais o lado visível da eternidade e parecem ensanguentados sob um grande volume de dores antigas e lágrimas. Os cabelos, de uma grave brancura, caem em duras e raras mechas no rosto mais iluminado e mais cansado do que qualquer coisa em torno dele, no silêncio atento da mesma floresta. As mãos finas estão rigidamente ligadas às coxas. À direita, seis velhos cegos estão sentados em pedras, cepas e folhas mortas. À esquerda, e separadas destes por uma árvore arrancada e pedaços de rocha, seis mulheres, também cegas, estão sentadas em frente aos velhos. Três delas oram e se lamentam, numa voz surda e interrupta. Outra é muito ve1ha. A quinta, numa atitude de demência muda, tem, sobre os joelhos, uma criança adormecida. A sexta é uma jovem luminosa, cujos cabelos inundam todo o seu ser. Elas, assim como os velhos, usam vestes amplas, escuras e uniformes. A maioria espera, cotovelos sobre os joelhos, rosto entre as mãos; e todos parecem ter perdido o hábito do gesto inútil e não dirigem mais a cabeça para os rumores abafados da ilha. Grandes árvores sepulcrais, teixos, salgueiros, ciprestes, os cobrem com suas sombras fiéis. Um tufo de longos asfódelos doentes floresce perto do sacerdote, na noite. Há uma escuridão profunda, apesar do brilho da lua, que aqui e ali, tenta afastar, por um momento, as trevas, das folhagens. ${ }^{13}$ (MAËTERLINCK, 1892, p. 75-76, tradução nossa)

13 "Une très ancienne forêt septentrionale, d’aspect étemel sous un ciel profondément étoile. Au milieu, et vers le fond de la nuit, est assis un très vieux prêtre enveloppé d'un large manteau noir. Le buste et la tête, 
No seu artigo, que trata de correspondências entre Maëterlinck e Samuel Beckett (1906-1989), Ewald Hackler (1983) acentua a qualidade dramatúrgica particular da qual está impregnada a peça Os cegos. Segundo Hackler (1983, p. 25), não há um "enredo" na peça: "[...] o guia de um bando de cegos, um padre, morrera numa excursão pela floresta; os cegos encontram-se sentados em volta do padre morto e aguardam sua volta" Hackler (1983) estabelece uma primeira comparação entre Maëterlinck e Beckett apontando similaridade entre Esperando Godot (Waiting for Godot, 1948/1949) e Os cegos: "[...] a categoria de ação, no drama, é substituída pela categoria de situação, a descrição da condição". (HACKLER, 1983, p. 25) E complementa a observação: "O drama como tradicional espaço da ação perdeu sua função original. Les aveugles não é mais drama, no sentido grego de dran (se é verdade que o verbo grego para ação é realmente a origem do substantivo)". (HACKLER, 1983, p. 25)

Szondi, por sua vez, comenta de falas que se deslocam paralelamente ou até em direção oposta em um "diálogo" que descaracteriza a reconhecida natureza do drama, como se pode ler no trecho abaixo:

$$
\begin{aligned}
& \text { Terceiro Cego - Está na hora de voltar ao asilo. } \\
& \text { Primeiro Cego - Precisamos saber onde estamos. } \\
& \text { Segundo Cego - Esfriou desde sua partida. }{ }^{14} \\
& \text { (MAËTERLINCK, 1892, p. 77) }
\end{aligned}
$$

Maëterlinck (1892) elaborou no seu texto compromissos entre uma imagem precisa e um diálogo fragmentado, entrecortado pelos sons da ilha. Há uma espécie de presença-ausência corporificada na imobilidade, pois o único que poderia ver e guiar o grupo é agora um cadáver. E mesmo os cegos que estão juntos há

\footnotetext{
légèrement renversés et mortellement immobiles, s’appuient contre le tronc d'un chêne énorme et caverneux. La face est d'une immuable lividité de cire où s'entr'ouvrent les lèvres violettes. Les yeux muets et fixes ne regardent plus du côté visible de l'éternité et semblent ensanglantés sous un grand nombre de douleurs immémoriales et de larmes. Les cheveux, d'une blancheur très grave, retombent en mèches roides et rares, sur le visage plus éclairé et plus las que tout ce qui l'entoure dans le silence attentif de la môme forêt. Les mains amaigries sont rigidement jointes sur les cuisses. - A droite, six vieillards aveugles sont assis sur des pierres, des souches et des feuilles mortes. À gauche, et séparées d'eux par un arbre déraciné et des quartiers de roc, six femmes, également aveugles, sont assises en face des vieillards. Trois d'entre elles prient et se lamentent d'une voix sourde et sans interruption. Une autre est très vieille. La cinquième, en une attitude de muette démence, porte, sur les genoux, un petit enfant endormi. La sixième est d'une jeu-nesse éclatante et sa chevelure inonde tout son être. Elles ont, ainsi que les vieillards, d'amples vêtements, sombres et uniformes. La plupart attendent, les coudes sur les genoux et le visage entre les mains; et tous semblent avoir perdu l'habitude du geste inutile et ne détournent plus la tête aux rumeurs étouffées et inquiètes de l'île. De grands arbres funéraires, des ifs, des saules pleureurs, des cyprès, les couvrent de leurs ombres fidèles. Une touffe de longs asphodèles maladifs fleurit, non loin du prêtre, dans la nuit. Il fait extraordinairement sombre, malgré le clair de lune qui, ça et là, s'efforce d'écarter un moment les ténèbres des feuillages."

14 “Troisième Aveugle-né. II serait temps de rentrer à l'hospice. | Premier Aveugle-né. II faudrait savoir oú nous sommes!| Deuxièmes Aveugle-né. | II fait froit depuis son depart."
} 
anos, não se conhecem. Resta esperar por alguém que permanecerá ausente, pois apesar de estar bem próximo e no centro da situação, encontra-se mergulhado no silêncio e na imobilidade da morte.

O lamento expresso na oração das três mulheres cegas estabelece a atmosfera sonora que se mostrará elemento essencial da situação, instalada na escuridão de uma floresta de árvores sepulcrais, situada em uma ilha. O corpo de um velho morto, no entanto, expressa a força visual da imobilidade que avança para a intriga "invisível" do diálogo. As posturas podem ser observadas como racionamento de movimento e a profundidade do som "mudo" e "surdo" é ampliada na morte, que se projeta dos lábios roxos de um rosto inerte, numa espécie de ritual ou cerimônia.

Szondi (1983, p. 221) afirma: "Tudo isso, finalmente, diz que as personagens estão longe de serem agentes causais ou sujeitos de uma ação. Eles são, simplesmente, objetos de uma ação". ${ }^{15}$

A categorização de "teatro estático" começa a ser justificada e a situação criada por Maëterlinck não parece conter ou encaminhar uma ação dramática. Segundo Hackler (1983, p. 25), como em outras obras da fase inicial da sua dramaturgia, Maëterlinck (1892) concebe uma peça cujo caráter musical parece sobreposto ao propósito visual. Trata-se de uma espécie de paradoxo, quando se concebe o teatro como arte do ver. Na sua primeira tentativa de romper o limite imposto pela ausência de visão, o Primeiro Cego não faz mais do que levantar e tatear. E logo depois, quando tenta dar um passo, ele tropeça, cai e diz: "Há alguma coisa entre nós [...]". ${ }^{16}$ (MAËTERLINCK, 1892, p. 78, tradução nossa)

Entre ele e seu "interlocutor" solidifica-se uma imensurável barreira, construída pela cegueira que limita a extensão do mundo ao limite do gesto, no corpo imóvel. A peça inscreve-se visualmente através de acontecimentos nos quais a incapacidade de ver define o extremo da situação.

Hackler cita também a análise de Max Dvořák ${ }^{17}$ (1874-1921) da pintura A queda do cego (Der blindensturz, 1568), de Pieter Breughel, o Velho (1525-1569):

[...] A natureza é indiferente... Em algum lugar alguns pobres cegos foram vítimas de um acidente... Ninguém vai dar atenção... Mas o que podia parecer um acaso, um acontecimento único, temporal e espacialmente limitado, incorpora o desti-

\footnotetext{
15 "All this finally says that the dramatis personae are far from being causal agents or subjects of an action. They are, quite simply, objects of an action."

16 "II y a quelque chose entre nous [...]"

17 Historiador austríaco, nascido tcheco, um dos nomes mais importantes da Escola de Viena, da História da Arte.
} 
no do qual ninguém consegue escapar e ao qual a humanidade inteira é cegamente submissa [Figura 110]. (DVOŘÁK apud HACKLER, 1983, p. 29)

Brueghel inspirou-se na parábola da contaminação escrita pelo evangelista Mateus (15,1-20), na qual ele reprova a atitude de cegos que, sendo guiados por outros cegos correm o risco de cair no abismo. Na versão apresentada pela pintura de Brueghel, o Primeiro Cego que estava guiando seus companheiros de jornada acabou de cair e, inevitavelmente, levará consigo os demais. A paisagem inclui uma igreja, ao fundo: nem mesmo a proximidade com Deus impedirá a queda do ser humano que não enxerga seu próprio caminho e se deixa levar por "guias".

Maëterlinck, por seu turno, enclausura os cegos no isolamento de uma ilha de cegueira e faz entrar em cena um cão que, podendo enxergar, escolhe seu lugar no mundo. O ser humano, no entanto, está preso à impotência e à ignorância.

Hackler (1983) sugere correspondências entre o teatro simbolista e o teatro do absurdo ou, melhor, entre Maëterlinck e Beckett, sublinhando o que denomina o "princípio artístico da contração", caracterizado pela exclusão de tudo aquilo que não é essencial à situação. Ele acentua ainda a passividade e destaca a "dialética estratégica" de Maëterlinck, que pinta a humanidade mergulhada no isolamento mortal de um infinito vácuo, cujo destino é a morte.

Como define Hackler (1983), trata-se de um retrato pavoroso e exato daquilo que se tornou o ser humano moderno, como se vê em Esperando Godot, onde não se reconhece uma pessoa e, se há dois nomes como Estragron e Vladimir, também está presente a variação tragicômica de Pozzo em Bozzo. A humanidade, por conseguinte, é a expressão do isolamento, da passividade e da ignorância, a caminho da morte.

Cada um pode "iluminar" a situação do modo que lhe aprouver. No entanto, investigando a dramaturgia como problematização visual, cabe uma pergunta: que luz constrói a imagem elaborada por Maëterlinck?

Por um lado, vale "inventar a própria luz" desprezando tal indagação, aceitando o risco de elaborar algo que já se encontra na dramaturgia, "inventando" o que já existe. Por outro, mesmo que o iluminador analise cuidadosamente a imagem criada por Maëterlinck, no momento da elaboração da cena, cada artista deveria ser capaz de incluir sua própria "marca" - ou kharakter (caráter), como já foi dito no capítulo A propósito da visualidade na cena, do presente trabalho - estabelecendo sua convicção visual. Essa marca será efetivada caso o iluminador, ao menos, leve em consideração uma variável relevante: ainda que se trate de uma situação extrema que ocorre no mais profundo da noite, numa floresta, na qual 
estão envolvidos cegos dependentes de um cadáver para continuarem vivos, há alguém que está presente porque deseja e precisa ver os acontecimentos: o espectador. A práxis cênica inscreve-se pela contundência visual de uma situação na qual, sendo o único que pode ver, o espectador ganha enorme poder. E tal poder só será efetivado através da luz, da imagem.

\section{SAMUEL BECKETT OU A ANGÚSTIA DO AUTOR DIANTE DA CENA}

A obra teatral de Samuel Beckett (1906-1989) poderia ter aparecido desde o primeiro capítulo do presente trabalho dada sua relevância para a história do teatro, da dramaturgia e, principalmente, para a abordagem da imagem visual teatral aqui desenvolvida. Beckett ganha espaço particular através do seu enfrentamento da angústia de um dramaturgo que vê na cena o destino da sua obra.

A observação da sua dramaturgia foi aqui incluída para acentuar que mesmo diante de uma obra com tamanha dimensão, quando se discute a realização teatral as funções da imagem visual são imediatamente sublinhadas. Afinal, ainda que o autor tenha inserido significativas indicações de luz em suas peças, sem um projeto (lighting design) apropriado, suas ideias não se efetivarão na cena. Serão comentados aqui aspectos muito específicos da sua obra, contemplando discussões particulares da investigação em curso.

Beckett fez mais que escrever peças. Ele deixou "partituras" cênicas e dirigiu espetáculos nos quais foram aplicados seus próprios textos. O termo partitura refere-se tanto à codificação presente na sua dramaturgia quanto ao controle que ele procurou exercer sobre o teatro do qual o texto dramático é um estágio da mencionada condição pré-cênica. De modo abrangente, o termo partitura é assim definido: "[...] notações impressas ou manuscritas, que mostram a totalidade das partes de uma composição [...]". (PARTITURA, 2009) Configura-se, então, uma maneira de escrever com o olhar voltado para o palco, na qual o dramaturgo busca incorporar a totalidade das funções de diretor, de cenógrafo e de iluminador, apresentando grande tendência musical.

As partituras escritas por Beckett incluem didascálias que definem o espetáculo e não podem ser lidas como adendos ao texto. O artista que as descarta estará efetivamente elaborando outra obra. A abordagem de tal assertiva evita acentuar a contenda entre o texto e a liberdade de cada diretor, interessando-se pela natureza da mudança que se processa quando se ignoram as didascálias de uma peça como Play, que será comentada adiante. Importa considerar que ignorar tais circunstân- 
cias com o intuito de propor um acontecimento espetacular autônomo não invalida a dramaturgia de Beckett em si, como um passo consciente em direção à cena.

A inclusão da obra de Beckett neste trabalho está justificada, também, quando se leva em conta que ele dirigiu espetáculos baseados nos seus próprios textos, estreitando os elos entre a dramaturgia e a cena. Reiterando o reconhecimento da imagem visual como aspecto intrínseco da atividade teatral desde as primeiras articulações de ideias da cena, ele contribui para a argumentação do presente trabalho. Beckett tem lugar aqui, afinal, devido ao rigor visual do seu teatro.

As relações entre o teatro de Beckett e a visualidade têm sido tema de diversos estudos que observam seu interesse pelas artes visuais, por ele mesmo registrado nos chamados Diários alemães (German diaries) nos quais aparecem anotações sobre suas visitas a museus, denotando um olhar atento voltado para a pintura. Várias dentre suas peças, entre elas Dias felizes [Happy days (1961)], Não eu [Not I (1972)], Passadas [Footfalls (1975)], e Monólogo [A piece of monologue (1977)] poderiam ser destacadas no contexto. Além disso, o estudo biográfico Condenado à fama: a vida de Samuel Beckett (Damned to fame: the life of Samuel Beckett), escrito por James Knowlson em 1996, fornece instigações para mais do que uma abordagem das relações entre sua obra e as artes visuais, mas também para o estudo da interação entre as artes visuais e a práxis cênica em si, de modo abrangente.

Outro elemento importante no contexto é a opinião de Lois Oppenheim (2000, 125, p. 125, tradução nossa): ${ }^{18}$ "[Beckett] dirigiu sua própria obra para assegurar a realização mais fiel de sua visão". ${ }^{19}$ Tal assertiva revela estreita ligação com um dos principais argumentos da presente investigação quando se sublinha o trabalho do dramaturgo como um estágio em direção à cena. O legítimo desejo de ver sua obra no palco está quase sempre presente na mente de um autor desde as mais incipientes ideias que levarão a um texto teatral até, de modo geral, na mais elaborada obra de dramaturgia.

Vale lembrar que escrever com o olhar na cena é uma tendência já estabelecida pelo teatro grego clássico, com Ésquilo, Sofócles e Eurípedes. Cada um deles escrevia o texto, trabalhava como ator, diretor e produtor dos seus espetáculos, elaborando uma simbiose triunfal na reunião das várias atividades da natureza compósita do teatro. Repercutindo a tendência, dramaturgos como Eduardo de Filippo (1900-1984), Samuel Beckett (1906-1989), Bertholt Brecht (1898-1956) e Dario Fó (1926-), depois de muitos outros, como William Shakespeare (1564-1616), Molière (1622-1673) e Johann Nestroye (1801-1862) escreveram com o olhar clara-

18 Pesquisadora, autora de alguns livros que abordam a obra de Beckett, professora da Montclair State University. 19 "[...] directed his own work to ensure the most faithful realization of his vision." 
mente voltado para o palco, incluindo decisões de natureza visual, nas quais cada aspecto incorporado à cena exige rigor de tratamento.

Ainda na opinião de Oppenheim (2000, p. 125, tradução nossa) pode ser observada outra nuança da questão: “[...], Beckett assumiu também a função de pintor, no palco. Seus atores comumente atestam isso". Billie Whitelaw ${ }^{20}$ assim escreveu sobre seu trabalho com Beckett, na montagem de Passadas (Footfalls):

[...] como se ele fosse um escultor e eu, uma peça de barro. Em outros momentos, eu poderia ser um pedaço de mármore que ele precisava desbastar. Ele movia insistentemente meus braços e minha cabeça, de certo modo, para chegar o mais perto da imagem precisa que tinha na mente. [...] Às vezes eu me senti como se eu fosse o modelo para um pintor [...] por vezes eu senti que estava sendo pintada com luz. ${ }^{21}$ (WHITELAW apud OPPENHEIM, 2000, p. 125, tradução nossa)

A montagem de Passadas à qual Whitelaw se refere estreou em 1976 no Royal Court Theatre, em Londres, juntamente com Play (cuja tradução para Comédia soa estranha e, por isso, aqui é mantido o título original) ${ }^{22}$ e (Nessa altura) That time, como parte do Festival Samuel Beckett. Para compreender as observações da atriz devem ser levadas em conta as diretas relações de Becket com as artes visuais. De acordo com Knowlson (1996, p. 57), ele visitou a Galeria Nacional de Dublin em 1926 e expandiu seu interesse através de contatos com "Boss" Sinclair, seu tio, envolvido em negócios com obras de arte. Beckett documentou inúmeras visitas a museus, durante vários anos, na Alemanha, na Irlanda, na Inglaterra e na França, demonstrando interesse diversificado, desde a escultura e a arquitetura, desde os grandes mestres da pintura italiana até a alemã moderna, além da predileção pela pintura holandesa e flamenga. Ele citou e comentou trabalhos de Johannes [Jan] Vermeer (1632-1675), Hieronimus Bosch (ca.1450-1516), Andrea Mantegna (14311506), Masaccio [Tommaso di San Giovanni di Mone (1401-1428)], Albrecht Durer (1471-1528), entre outros.

Lois Oppenheim (2000) menciona, dos Diários alemães (German diaries, fevereiro de 1937), os comentários de Beckett acerca da pintura San Sebastiano (1476-

\footnotetext{
20 Atriz inglesa, nascida em 1932, trabalhou com Beckett durante 25 anos, e é considerada uma das suas mais importantes intérpretes.

21 "[...] as if he were a sculptor and I a piece of clay. At other times I might be a piece of marble that he needed to chip away at. He would endlessly move my arms and my head in a certain way, to get closer to the precise image in his mind.[...] sometimes I felt as if I were modeling for a painter [...] I felt I was being painted with light."

22 O título desse texto tem sido traduzido como Comédia, o que não parece boa solução. Peça, simplesmente, serve aos propósitos do presente trabalho.
} 
1477), de Antonello da Messina (ca. 1430-1479), nos quais ele parece tocado pela distribuição das personagens na composição, sublinhando o contraste entre o homem executado no primeiro plano da imagem e a atmosfera cotidiana das ações que elaboram a composição (Figura 111). Beckett (apud NIXON, 2011, p. 147) constatou: "[...] É bom estar vivo". Revela-se a intenção de aproximar-se da obra mais do que numa simplória visita turística a um museu. Essa atitude deixa marcas que aparecerão 11 anos depois, numa carta escrita para Georges Duthuit, em primeiro de fevereiro de 1948:

Puro espaço sob a força da matemática... e a lápide [sic] expõe, dando-se à admiração de cortesãos que respiram o ar dominical na varanda, tudo invadido, consumido pelo humano. Diante de uma obra como essa, diante de tal vitória sobre a realidade da desordem, na pequenez do coração e do espírito, quase nos enforcamos. ${ }^{23}$ (BECKETT apud NIXON, 2011, p. 147, tradução nossa)

A imagem deixou fortes impressões originadas no rigor perspectivista e na idealização da representação pictórica. E ainda que se possa considerar o interesse de Beckett pelas artes visuais como uma característica de um autor cuja obra que transita na fronteira entre a dramaturgia e outras linguagens, é importante observar que tal curiosidade visual parece haver se configurado como estudo com alguma sistematização, repercutindo de modo contundente, não somente na sua dramaturgia, mas também nos seus espetáculos.

Tomando como exemplo o mencionado texto, Passadas, vê-se que as imagens estão submetidas ao mesmo rigor que um pintor, um escultor, ou qualquer outro artista seriamente interessado na assertiva visual impõe à sua obra. Beckett elabora uma contradição radical na relação entre o desequilíbrio da figura esfarrapada de May e seu deslocamento no espaço rigorosamente, teatralmente controlado.

O que se deve ver em cena na abertura do espetáculo, segundo as palavras de Beckett (1984a, p. 237, tradução nossa), é: "May (M), cabelo grisalho despenteado, pés escondidos por desgastados invólucros cinza, arrasta-se". ${ }^{24}$ Uma imagem precisamente definida, concreta, descrita graficamente por Beckett. Cada aspecto foi selecionado para que May seja identificada como um ser em estado deplorável, que deve ser reconhecido pelo observador através de uma descrição "realista", fugurativa, poder-se-ia dizer.

23 "Espace pur a force de mathematique... et le lapide [sic] expose, s'exposant a l'admiration des courtisans prenant l'air dominical au balcon, tout ça envahi, mangé par l'humain. Devant une telle oeuvre, une telle victoire sur la realite du désordre, sur la petitesse du coeur et de l'esprit, on manque se pendre."

24 "May (M), dishevelled grey hair, worn grey wrap hiding feet, trailing." 
Ainda que a disposição gráfica do espaço e da ação possa levar a uma leitura que indica abstração, Beckett concebeu visualmente de modo objetivo essa figura desgastada que pode indicar descuido, imprecisão. Para dizer de maneira simples e explícita: ele cria um intenso contraste entre um espaço cênico de aguda precisão geométrica e uma personagem cuja aparência indica o descontrole e o desequilíbrio de uma figura maltrapilha. Sintomaticamente, a desgrenhada May desloca-se em movimentos rigorosamente ordenados, gerando, já no discurso visual, um choque. Tal rigor fica explícito desde a primeira página do texto que até inclui orientação gráfica da movimentação.

Como uma figura que sugere desequilíbrio ou instabilidade desloca-se de modo tão regular e preciso? É uma visão perturbadora, teatral, artificialmente planejada que, apresentando índices figurativos importantes na construção da personagem e da situação, estabelece o choque mencionado. Revela-se uma pessoa atacada por circunstâncias que criam uma imagem de deterioração, mas que caminha de maneira uniforme, definida, regular. Simples, uma ação simples, vigorosa.

O depoimento da atriz revela a natureza multirreferencial da montagem e determina a importância que o autor diretor emprestava à sua visualidade:

Em Passadas, me senti como uma pintura musical de Edvard Munch em movimento [...] e, de fato, quando Beckett estava dirigindo Passadas, ele não estava apenas me usando para tocar notas, mas eu quase senti que ele empunhava um pincel e estava pintando e, é claro que o que ele sempre tinha no outro bolso era uma borracha, pois tão rápido quanto desenhava uma linha ele passava a enorme borracha, apagando-a, até que mal se podia vê-la. ${ }^{25} 26$ (JOURNAL OF BECKETT STUDIES, 1978, p. 89, grifo nosso)

Dispensados os julgamentos da direção de Samuel Beckett, do seu processo de fazer e apagar, o que importa aqui são suas decisões como autor. Considere-se, no entanto, a abordagem de um hipotético Samuel Beckett, diretor, que decide atender as indicações do autor. Destaque-se a luz para ponderar que mesmo com o rigoroso controle por ele proposto, certos detalhes podem se insinuar como

25 "In Footfalls, I felt like a moving musical Edvard Munch painting [...] and in fact when Beckett was directing Footfalls, he was not only using me to play notes, but I almost felt that he did have the paintbrush out and was painting, and, of course that he always has in the other pocket is rubber, because as fast as he draws a line in, he get out that enormous India-rubber and rubs it out until it is only faintly there."

26 Trecho de uma entrevista espontânea com Billie Whitelaw, por James Knowlson, uma gravação para a televisão, efetuada em 1 fev. de 1977 . 
objetos de discussão. Antes de tudo, temos um locus cênico concebido como um espaço sem luz no qual é destacada uma faixa iluminada no piso, à frente, com um metro de largura e extensão horizontal suficiente para comportar nove passos de May cuja cabeça deve estar na penumbra, ampliando a intensidade da luz à medida que o observador dirige sua atenção aos pés. A quantidade de passos, as pausas entre as falas, e os momentos de imobilidade são rubricas indispensáveis para a compreensão do texto e da sua repercussão no espetáculo. Há, no entanto, questões referentes à imagem visual que tornam importante a presença de um iluminador, uma vez que Beckett (1984a, p. 237, tradução nossa) não deixou um projeto. Ele escreveu: "Luz: em resistência [penumbra], maior intensidade no piso, menor no corpo, ainda menor na cabeça". 27

Visualmente simples: acentuação nos pés, progressivamente reduzindo a intensidade, elaborando virtualmente a personagem em uma gradação que trata os pés, o corpo e a cabeça numa transição sem fronteiras visuais bruscas entre uma e outra parte da figura.

Um projeto eficiente com especial atenção para a escolha, distribuição e manipulação dos instrumentos e acessórios indicados resolveria parte dos problemas da luz, no espetáculo. Ainda há, contudo, indagações referentes à cor, especificamente à cor da luz, uma vez que a penumbra indicada pelo texto pode resultar em armadilha, pois não basta apenas reduzir a intensidade duma lâmpada, ou das lâmpadas, estabelecendo uma penumbra genérica. O próprio texto de Beckett (1984a, p. 240, tradução nossa) indica uma aparente solução, quando May diz, depois de uma pausa: "Esfarrapada [Pausa] Um emaranhado de farrapos. [Pausa] Observa-a, a ela que passa diante do candelabro, como suas chamas, sua luz [...] como a lua passando através da grade". ${ }^{28}$

A inclusão do candelabro pode estabelecer uma contradição do ponto de vista cromático, uma vez que ele pode sugerir uma luz amarelada alcançando provavelmente os alaranjados da incandescência influenciada pelos vermelhos, o que resultaria num tratamento visualmente suave, confortável, até romântico. Por outro lado, há uma referência à lua. Entretanto, de que lua May (ou Beckett) está falando? Ou de que lua a cena precisa? De um tom levemente alaranjado, como se poderia ver numa lua que nasce refletindo a família cromática do pôr do sol; ou uma (falsa) lua romântica que emitiria, talvez, azuis repletos de vermelho, mas com o indispensável cuidado de permanecer entre os violetas, evitando a artifi-

\footnotetext{
27 "Lighting: dim, strongest at floor level, less on body, least on head."

28 "Tattered. [Pause] A tangle of tatters. [...] Watch her pass before the candelabrum, how its flames, their light... like moon through passing rack."
} 
cialidade dos magentas, ausentes na luz natural? Como já se pode notar, o encaminhamento de tal discussão envolveria detalhes técnico-estéticos somente acessíves, ou do interesse, de um leitor muito familiarizado com o contexto. Algumas questões são, contudo, muito estimulantes para o iluminador e serão brevemente mencionadas.

Observando a peça com atenção, pode-se diagnosticar que Beckett (1984a, p. 240, tradução nossa) indicou respostas para as indagações sobre cor, já no momento anterior da fala mencionada acima: "A semelhança. Em resistência [penumbra], nunca invisível, sob certa luz [Pausa]. Dada a luz correta. [Pausa] Cinza, ao invés de branco, um tom pálido de cinza". ${ }^{29}$ Mesmo que não tenha explicitado tecnicamente a cor do filtro (ou gelatina), ele deixa portas abertas para discussões sobre o problema, ficando ao diretor considerar essa fala, eleger outra saída qualquer, ou deixar ao acaso. Mas, o cinza pálido, de baixa intensidade, visualmente frio, contudo, incorpora uma provocação visual intrigante.

Qual seria a melhor opção para essa peça, considerando a atmosfera descrita pelo autor? Como exemplos, uma atmosfera romântica, macia, suave, ou um ambiente frio, cortante, como a lua na ópera Don Giovani de Mozart, quando o dissimulado Giovani faz a "apaixonada" serenata para Elvira, uma nobre que ele seduziu e abandonou?

Como já foi dito, seria exaustivo e enfadonho para o leitor em geral a transformação da presente abordagem em um seminário técnico-estético sobre a luz em Passadas. Ao interesse da discussão basta a compreensão da visualidade proposta por Beckett como projeto relativamente simples, mesmo registrando que as imagens por ele indicadas estão relacionadas à aplicação de acessórios específicos e ainda pouco usados em algumas comunidades, como os filtros de densidade neutra (ND) cuja aplicação em conjunto com determinados filtros azuis operam na temperatura de cor das lâmpadas - incandescentes, com filamentos de tungstênio e gás halogênio no interior do bulbo, responsáveis pela família cromática dos amarelos alaranjados - poderiam promover o encaminhamento da atmosfera cinzenta de frieza e desconforto. Como se pode imaginar, bem diferente de um ambiente iluminado por um candelabro, que poderia resultar numa atmosfera acolhedora. Decisões simples, mas acompanhadas da precisão e do detalhamento técnico indispensável ao theatre lighting design.

Discussões semelhantes poderiam contribuir de modo positivo em ambientes nos quais a visualidade da cena representa investigação específica. A qualidade

29 "The semblance. Faint, though by no means invisible, in a certain light. [Pause] Given the right light. [Pause] Grey rather than white, a pale shade of grey." 
das imagens cênicas está relacionada a um conjunto de variáveis que incluem ângulo, intensidade, textura, movimento, e assim por diante. Tal abordagem pode desagradar quem busca fórmulas para seguir um "como se faz", pois tais variáveis interagem com outras tantas, como o espaço de cada espetáculo em questão, assim como cada composição em si, o que desafia a mera cópia de resultados ou aplicação de receitas.

Tal enfoque pode parecer insuficiente e/ou desagradar quem espera uma minuciosa análise da dramaturgia. O presente momento do texto, contudo, exige que determinadas especificidades do trabalho do iluminador sejam acentuadas, sublinhando que mesmo as rigorosas "partituras" escritas por Samuel Beckett acabam por se configurar como provocações que exigirão criteriosa seleção de atitudes, envolvendo aspectos técnico-estético-poéticos capazes de apontar respostas cênicas para a dramaturgia.

E nem se mencionou que, em Passadas, a luz da lua se projeta através de grades - incluídas no texto de Beckett. Isso poderia possibilitar a revelação das "grades" sobre o espaço cênico. Causaria surpresa confirmar que não se tenha buscado tal possibilidade, até hoje. Ou seja, mais do que "inventar" uma mirabolante saída "criativa", pode-se também optar pela pesquisa em laboratório de luz, como opção de investigação visual: quais seriam os resultados das imagens cênicas em Passadas, numa montagem que incorporasse a luz emitida pela lua, passando através de grades?

Entre outras obras de Beckett que permitem observar as relações entre o dramaturgo e a cena pode-se destacar o texto Play, escrito em inglês nos anos de 1962/1963 e publicado pela primeira vez numa tradução alemã de Erika e Elmar Tophoven com o título Spiel, na revista Theater heute, em julho de 1963. O primeiro espetáculo da versão alemã estreou no Teatro Ulmer, Ulm-Donau, em 14 de junho de 1963. Publicada pela primeira vez na língua inglesa em 1964, a peça estreou na Grã-Bretanha com a Companhia Nacional de Teatro, no Teatro Old Vic, em Londres, no dia 7 de abril de 1964 .

Seis anos mais tarde, foi produzida uma versão cinematográfica francesa, denominada Comédie que, parece óbvio, trata-se de outra obra; menos no que se refere à tradução da dramaturgia e mais, se considerarmos a condição de imagem gravada e reproduzida em movimento diante do público, sem a presença dos atores e, tampouco, do operador de mesa de controle de luz.

A importância do ator como presença viva no teatro já confirmou seu espaço na discussão da práxis cênica; Beckett, no entanto, sublinha a função categórica do operador da mesa de controle de luz. Ao longo da história da dramaturgia, 
encontramos textos nos quais os autores procuram fornecer um grande volume de indicações para o diretor, o que pode levar a julgamentos apressados que consideram menor o trabalho do diretor, pois ele apenas seguiria tais indicações.

Problematizando a angústia do dramaturgo diante da incompletude do drama e, por conseguinte, da sua própria impotência diante da cena, será aqui observado um texto realista que por sua natureza representativa, presume-se, deva apresentar uma extensa descrição daquilo que deve ocorrer no acontecimento cênico, sonegando de diretores e atores o direito de "criar". Assumindo também a função de diretor, o autor seria capaz de completar os lapsos de ação, tempo e espaço, "deixados" pela dramaturgia.

Para discutir tais lapsos será brevemente comentada a peça em um ato $O$ Canto do cisne, de Anton Tchékhov (1860-1904), escrita em 1888. A importância da escotha de Tchékhov fica evidente quando se leva em conta que se trata de um dos mais reconhecidos e, portanto, mais atacados representantes do teatro realista.

Em O canto do cisne, Tchékhov (2001) expõe, ou desnuda em cena, o homem por trás do ator Svetlovídov, personagem central da trama. Não é o seu talento artístico que está em discussão, mas sua dor. Sua alma é revolvida diante do espectador que, na verdade, vê muito além da peça na qual ele tomou parte, como alguém que adentra um palácio requintado pelos aposentos dos serviçais, pela cozinha, pela lavanderia. O glamour do teatro perde relevância nesse contexto, tornando-se referência para a crueza de um palco sem "espetáculo".

A rubrica inicial indica a imagem cênica vislumbrada por Tchékhov (2001, p. 25):

A ação transcorre no palco de um teatro de província, à noite, depois do espetáculo. Um palco despojado de um teatro provinciano de segunda categoria. À direita, uma fileira de portas sem pintura e malpregadas, que levam aos camarins; o plano esquerdo e o fundo do palco estão atulhados de cacarecos. No centro do palco, um banco caído. Noite. Escuridão.

A descrição do ambiente é empreendida com grande rigor, configurando uma das muitas razões para críticas ao realismo, integrando a demanda por um novo teatro no século XX. A qualificação de despojamento usada mais tarde como sinônimo do avanço estético das vanguardas é aplicada pela tradução para sublinhar negativamente o espaço onde ocorre a ação e para representar o resultado de limitações econômicas, além do mau gosto, do descaso e/ou da ignorância, como em tantos espaços que um artista do teatro da primeira metade do século XXI pode ainda encontrar. Tchékhov vai adiante e completa o que se poderia chamar cenografia, incluindo portas à direita, que além de malpregadas não foram sequer 
pintadas, denotando desleixo e/ou falta de recursos. Vale destacar: essas portas levam aos camarins que, portanto, são expostos ao público; não se trata de portas construídas como elementos de um dispositivo cenográfico, mas da própria arquitetura do teatro. Presentes em cena durante a representação, contudo, elas constituirão o dispositivo cenográfico, uma imagem que inclui "cacarecos" amontoados à esquerda e ao fundo (em relação ao ponto de vista do espectador). Há um banco, caído, ao centro.

Sem contar com a informação visual de desenhos, o leitor cria imagens mentais como resposta a tais provocações. Para o espectador, quando o cenógrafo, o aderecista, o iluminador e o diretor, o músico, dentre outros, assumem a posição de leitores, eles ganham elevada importância, pois assumirão a função de elaborar em parceria as imagens que efetivamente serão criadas na cena. Tratando-se do teatro realista essas leituras devem atender a compromissos com a lógica e com o estudo da imagem no intuito de elaborar um espaço que responda às proposições do autor, norteando-se pela unidade e pela precisão. Cumprida essa fase, conta-se com a capacidade do diretor e do ator para fisicalizar a cena provocada pelo texto, cuja ação ocorre em um ambiente fechado, na escuridão da noite. Abre-se a cortina de boca. Tchékhov (2001) não dá qualquer indicação de uma fonte de luz artificial que possa promover a visibilidade do ambiente. O que se vê? Noite, escuridão. Num ambiente externo, à luz da lua ou de eventuais fontes de luz artificial seria possível distinguir visualmente o lugar, mesmo em traços suaves e/ou disformes. Mas o autor é categórico: escuridão. Portanto, nada se enxerga; o palco é um buraco negro. Fica a impressão de que não há ninguém naquele lugar; ativo ou acordado; se alguém dorme está distante, em um espaço fechado, ou em completa escuridão. O autor descreve a ação: "Svetlovídov, ${ }^{30}$ (em trajes de Calchas, ${ }^{31}$ com uma vela na mão, sai de um camarim rindo às gargalhadas)”. (TCHÉKHOV, 2001, p. 25)

A rubrica sugere ponderações. Em primeiro lugar, há mais de uma porta: de onde ele sairá? Antes de sair, no entanto, ele procura uma vela e, depois de acendê-la, abre a porta. Ou a porta escolhida já se encontrava aberta? Cada diretor deve decidir, inaugurando uma parceria com o dramaturgo, incorporando um cenógrafo, um ator, um figurinista, um maquiador e um aderecista, quando menos. Mesmo que alguém assuma todas essas funções, ou que uma ou mais dentre elas seja desempenhada por um artista, as funções estarão presentes.

\footnotetext{
$30 \mathrm{Na}$ nota do tradutor, o sobrenome Svetlovídov é formado pelas palavras sviétli (iluminado, luminoso) e vid (aspecto, aparência, semblante).

31 Personagem da tragédia de Shakespeare, Troilus e Cressida, Calchas é o pai de Cressida.
} 
Se o diretor toma a decisão de manter como única fonte de luz na cena a vela trazida pelo "iluminado" Svetlovídov fica dispensada a contribuição de um iluminador. Será a vela, no entanto, suficiente para que o espectador apreenda o ambiente descrito pelo autor? Aqui se identifica uma abordagem provocadora para um interessado em pesquisar a luz aplicada ao espetáculo: elaborar a cena sem acrescentar nenhuma fonte de luz além da vela descrita por Tchékhov, investigando a percepção visual dos espectadores e o efetivo resultado que uma vela produziria nessas condições, prevendo variáveis, como as dimensões de cada espaço onde a peça venha a ocorrer, a duração da cena, associadas à visão escotópica e eventualidades, como uma vela que se apaga durante a ação dramática, para mencionar exemplos.

Do ponto de vista da ação propriamente dita, o autor informa que Svetlovídov sai do camarim vindo de uma porta, uma entre as mais próximas (do espectador). Já se tratou da questão acima. Sabe-se que, durante a sua primeira longa fala ele levanta o banco caído ao centro e se senta. Mas como ele chegou lá? As respostas são simples, pois se encontram no reconhecimento demonstrado pelo dramaturgo das limitações da sua contribuição. Ele espera que diretor e ator preencham essas lacunas. Isso, aliás, ao invés de traço negativo pode representar a afirmação da flexibilidade e da natureza compósita da arte teatral. Adiante, nessa mesma fala, Tchékhov (2001, p. 26) inclui outra rubrica intrigante: "[Svetlovídov] Vira a cabeça de um lado para outro". Como assim? E o que ele fez até agora? Permaneceu imóvel, congelado?

Uma didascália dessa natureza demonstra, por um lado, o esforço do autor para alcançar a maior aproximação possível com o leitor. Ou seja, ele reconhece sua limitação; por outro, o que foi acima denominado lapso só pode ser compreendido no próprio devir da dramaturgia, que inclui relações dinâmicas com a ação cênica. Tais lapsos, no entanto, não são feições exclusivas do realismo, podendo também ser encontrados nas mais revolucionárias versões das "antiteatralidades" ou novas teatralidades. Mas eles podem ocorrer, também, num evento originado em um roteiro considerado incompleto, sem precisão, com ausência de rigor, insuficientemente descritivo. Pondere-se, então: se um diretor apenas obedece aquilo que o dramaturgo prescreve, raramente um texto promoverá um espetáculo.

Em sua peça Play, Beckett tomou decisões radicais, nos moldes da partitura já mencionada, indicando soluções para tal natureza de problemas. Sem a intenção de fazer uma análise alongada do texto serão destacados pontos importantes para sua abordagem, e mesmo que a peça já tenha sido exaustivamente comentada é preciso registrar que ela trata do chamado "Eterno Triângulo" como imagem que representa uma situação de adultério. A denominação das personagens (se é permitido usar 
tal termo, no caso) como W1, W2 e M, que parecem indicar Mulher 1, Mulher 2 e Homem, demonstra a estratégia dramatúrgica que, por sua vez, pode provocar as escolhas efetivadas na definição do seu tratamento visual.

A didascália inicial de Play pode assustar aqueles mais conservadores e, talvez, mergulhar em um poço sem fundo os mais afoitos, de leitura superficial, que podem alegar ditadura do texto, ou da palavra:

A partir do centro, três urnas cinza de aproximadamente noventa centímetros, tocam-se. | De cada uma delas projeta-se uma cabeça com o pescoço mantido firme na extremidade. Essas cabeças estão, do ponto de vista da plateia, da direita para a esquerda $\mathrm{m} 2$, h e m1. Todos olham para a frente, na direção do público, durante toda a ação. Os rostos têm uma aparência indefinida na idade e no aspecto, como se fizessem parte das urnas. Mas não usam máscaras. | As falas são provocadas por uma luz projetada apenas nas faces... | A mudança de luz de uma face para a outra é imediata. | Não há black-outs, i. e., não se retornará para a quase completa escuridão do início, exceto onde existe uma indicação [do texto]. |A resposta à luz é imediata. | As faces permanecem impassíveis. As vozes não apresentam nenhuma entonação, exceto quando uma expressão é | indicada [pelo texto]. | Tempo [andamento] rápido durante todo o espetáculo. | A cortina sobe mostrando um palco em quase completa escuridão. | Mal se distinguem as urnas. Cinco segundos. | Focos suaves, simultaneamente, nas três faces. Três segundos. Voz fraca, em grande parte | ininteligível. ${ }^{32}$ (BECKETT, 1984b, p. 145, grifo e tradução nossos)

Uma rubrica que por si só justifica a presença de Beckett na discussão em curso. Em primeiro lugar, cabe problematizar o que ele chama de palco: "[...] um palco quase em completa escuridão. As urnas quase não são identificadas"33 (BECKETT, 1984b, p. 145, tradução nossa). Na verdade, o "palco" ou "espaço ideal", como ele mesmo

\footnotetext{
32 "Front center touching one another, three identical grey urns about one yard high. | From each a head protrudes, the neck held fast in the urn's mouth. The heads are | those, from left to right as seen from auditorium, of w2, $\mathrm{m}$ and $\mathrm{w} 1$. They face | undeviatingly front throughout the play. Faces so lost to age and aspect as to seem | almost part of urns. But no masks. | Their speech is provoked by a spotlight projected on faces alone. | The transfer of light from one face to another is immediate. | No blackout, i.e. return to almost complete darkness of opening, except where | indicated. | The response to light is immediate. | Faces impassive throughout. Voices toneless except where an expression is| indicated. | Rapid tempo throughout. | The curtain rises on a stage in almost complete darkness. | Urns just discernible. Five seconds. | Faint spots simultaneously on three faces. Three seconds. Voice faint, largely | unintelligible."

33 "[...] a stage almost in complete darkness. Urns just discernible."
} 
denomina, não passa de uma região na penumbra, determinando qualidade visual específica para o ambiente proposto pelo dramaturgo. Ao escrever palco, ele descaracteriza ligações com lugares do cotidiano: "palco", no contexto, indica qualquer que seja o espaço no qual a situação esteja efetivamente ocorrendo, abolindo referências aos ambientes do chamado "mundo real".

Ainda assim, é relevante lembrar que Beckett incluiu uma cortina. Ele afirmou que faces e urnas parecem um só corpo, como se fossem feitos do mesmo material: a descrição parece aproximar a situação na qual Play está instalada, o refúgio-prisão no qual se encontrava o ser humano moderno, atado aos hábitos e ao seu lugar banal. Uma borboleta que faz uma transmutação inversa, aprisionando-se numa crisálida de valores e normas, findando por rastejar.

O autor exige: não podem ser usadas máscaras. Se, como exemplo, for aplicado um acessório de maquiagem que, com a interferência da luz e a consequente projeção de sombras próprias no corpo do ator denuncie o acessório implantado, como algo imposto ao seu corpo, será destruída a ilusão exigida por Beckett. Esses corpos desenvolveram certa simbiose com uma espécie de urna-situação-lugar, levando à mixagem das suas texturas e cores, tornando-se difícil apreender diferenças definitivas e/ou limites entre um e outro.

Depois do primeiro dueto envolvendo $\mathrm{W}_{1} \mathrm{e}$ W2, o autor reitera o papel que a luz pode desempenhar, identificando seus limites: "[Spots apagados. Black-out. Cinco segundos. Poderosos spots simultaneamente nas três faces. Três segundos. Vozes com força normal.]".34 (BECKETT, 1984b, p. 145, grifos e tradução nosso) Cada um e todos os aspectos do trecho citado, exceto as "vozes com força normal", somente podem ser criados, registrados e controlados, pela luz.

Como se pode constatar, há questões que nem sempre estão diretamente subordinadas ao dramaturgo e ao diretor, mas que precisam contar com algum responsável pelas imagens visuais, o iluminador, para reconhecê-las e encaminhá-las como problematização visual na cena.

Quando Beckett (1984b) descreve o posicionamento das urnas levando em conta a visão de quem está na plateia, ele faz uma abordagem do espaço cênico que difere da convenção aplicada na dramaturgia de língua inglesa na qual se escreve do ponto de vista de quem está em cena. Beckett (1984b), ao contrário, reafirma a posição de alguém que vê a cena de fora, vê como um diretor, um cenógrafo, um iluminador e, entre outros, o espectador.

34 "[Spots off. Black-out. Five seconds. Strong spots simultaneously on three faces.Three seconds. Voices normal strength.]." 
E é preciso citar a orientação para a luz que Beckett (1984b, p. 159, tradução nossa) escreveu ao final do texto:

A fonte de luz é simples e não deve estar situada fora do espaço ideal [palco] ocupado por suas vítimas. A melhor posição para o refletor é o centro da ribalta, iluminando as faces de perto e de baixo. Quando, excepcionalmente, três refletores [instrumentos] forem necessários para iluminar as três faces ao mesmo tempo, eles devem funcionar como um instrumento desmembrado em três. Fora esses momentos, um refletor móvel deve ser usado, deslocando-se rapidamente de uma face a outra, conforme necessário. O método que consiste em atribuir para cada face um refletor fixo e separado é insatisfatório, uma vez que ele expressa menos a figura de um inquisidor, do que um só refletor que se desloca em direção às personagens. ${ }^{35}$

Podem ser vislumbradas imagens que ele desejava criar. Leve-se em conta que suas detalhadas orientações podem estar sujeitas a muitas variáveis técnicas envolvendo, entre outros aspectos, desde a distância entre as urnas e os spotlights (refletores, instrumentos), o tipo de instrumento, localização do técnico que fará a manipulação do mesmo, além das sombras projetadas pelas cabeças. Se tais sombras forem vistas pela plateia, o espaço da "situação" será bastante alargado prolongando sua extensão até o ponto no qual elas estejam projetadas, deslocando o centro de atenção.

Outro aspecto da questão é a precisão exigida do técnico que executará os movimentos, incluindo o tempo calculado em segundos, assim como a concentração de luz exclusiva em uma ou mais faces. Deve-se enfatizar que, tanto uma indicação que pareça muito generalizada quanto as específicas descrições apresentadas por Beckett, exigem um elevado grau de atenção do iluminador.

Beckett, bem se poderia dizer, além de assumir a posição de dramaturgo-diretor, aventura-se também no papel de designer, pois, além de escrever a mencionada partitura dramático-cênica e dirigir o espetáculo ele também parece impelido a conceber o projeto de luz. E, se o fizesse, estaria garantindo a precisão das imagens cênicas da sua dramaturgia.

\footnotetext{
35 "The source of light is single and must not be situated outside the ideal space (stage) occupied by its victims. The optimum position for the spot is at the centre of the footlights, the faces being thus lit at close quarters and from below. When exceptionally three spots are required to light the three faces simultaneously, they should be as single spot branching into three. Apart from these moments a single mobile spot should be used, swivelling at maximum speed from one face to another as required. The method consisting in assigning to each face a separate fixed spot is unsatisfactory in that it is less expressive of a unique inquisitor than the single mobile spot."
} 
Por outro lado, tal detalhamento pode ser interpretado como a mencionada angústia de um autor que precisaria ocupar as posições de diretor, de cenógrafo, de maquiador e de iluminador, dentre outras, para - e somente dessa maneira - garantir que as imagens cênicas presentes na sua dramaturgia fossem elaboradas no palco.

Registrando a inexorável atuação da luz na sua ideia de espetáculo, Beckett faz de Play um manifesto em favor da presente abordagem. Enquanto escrevia a peça, ele concebia sua dramaturgia como devir, caracterizando um movimento de natureza ontológica que projeta entre a dramaturgia e a práxis cênica uma trajetória não linear, transversal, na qual interagem vários aspectos. Play, como toda peça, é uma exclamação da dramaturgia arremessando-se em direção ao espaço cênico.

No teatro realista, as personagens falam impulsionadas por fortes desejos, uma vez que as palavras - as falas - são, entre vários outros, aspectos de uma ação. Uma das principais características do texto dramático - aquele no qual se faz presente o conflito - é, precisamente, as provocações às quais uma personagem é submetida. Tais provocações são geradas, inclusive, pelos seus próprios desejos. Ou seja, uma personagem ganha lugar no drama porque as provocações às quais ela é exposta resultam em ações que transformam sua vida em material que desperta o interesse do teatro.

$\mathrm{O}$ ato de provocar merece especial atenção em Play, uma vez que as cabeças reagem a provocações da luz. Poder-se-ia até dizer que tais reações não passam de reflexão - ou seja: a resposta física de um corpo à incidência de luz sobre sua superfície. Beckett (1984b, p. 147, grifo e tradução nossos) introduz a luz como provocação, segundo suas próprias palavras, e até remete a um inquisidor postado diante de um suspeito: "Suas falas são provocadas por um spotlight ${ }^{36}$ projetado somente nas faces. | A transferência de luz de um rosto para o outro é imediata". ${ }^{37}$ Mesmo sem nunca tratar de cor, que deve ser sempre uma preocupação preponderante, Beckett (1984b, p. 147, grifo e tradução nossos) define o tempo e, mais tarde, exige intensidade reduzida e focos suaves: "Urnas ligeiramente visíveis. Cinco segundos. Spots em resistência [baixa intensidade] nas três faces". ${ }^{38}$

\footnotetext{
36 No Brasil, pode-se traduzir como refletor, o que me parece um termo incompleto, de reduzida precisão técnica, mais apropriado para o senso comum. Quando não há necessidade de especificar a fonte de luz usada na situação, prefiro chamar de instrumento (aplicado para a produção de luz artifical na cena), o que pode se referir tanto ao mais recentemente cobiçado aparato, dotado da mais avançada tecnologia, quanto a uma simples vela de parafina. $\mathrm{Na}$ cena, um ou outro será o instrumento aplicado, de acordo com a excelência da imagem pretendida.

37 "Their speech is provoked by a spotlight projected on faces alone. | The transfer of light from one face to another is immediate."

38 "Urns just discernible. Five seconds. Faint spots simultaneously on three faces. Three seconds."
} 
Ao mencionar um spotlight - ou spot - no entanto, ele estabelece uma generalização que, na abordagem de um designer, seria avaliada com rigor. A disponiblidade de spotlights na época em que ele escreveu a peça se transformou hoje em uma multiplicidade que exige precisa especificação do equipamento a ser usado, mesmo que seja apenas um spotlight. Mais uma vez, o leitor não familiarizado será poupado, pois tratar tecnicamente da questão exigiria um texto muito específico e longo. No entanto, deve ficar um alerta: sem um projeto que defina precisamente o mencionado spotlight, os resultados podem ser inesperados e de difícil controle.

Em Play, a luz atua como uma espécie de regente que define a qualidade visual-musical do espetáculo, contribuindo para o tema: o andamento, o ritmo e a melodia propostos por Beckett, numa ação que alcança em certos momentos qualidade operística nos quais os duetos e trios funcionam tanto como palavra, quanto como som.

Depois da primeira fala, pronunciada simultaneamente pelas três figuras, há dois movimentos na imagem. Primeiro, as cabeças ficam sem luz e, em seguida, há um black-out. Após exatos cinco segundos as três cabeças são atingidas por uma luz de grande intensidade e "saltam" em direção ao espectador. Após mais uma fala dita ainda por todas as figuras, os movimentos na imagem se repetem: as cabeças ficam sem luz e, mais uma vez, um black-out; Exatos cinco segundos mais tarde, as três cabeças devem receber um golpe da luz. Beckett não faz qualquer observação sobre a intensidade. Levando em conta o padrão estabelecido na peça, uma vez que ele sempre registra diferenças necessárias pode-se presumir que as cabeças recebem o mesmo "ataque", ou a mesma qualidade de luz que antecedeu ao black-out.

Durante toda a peça, a luz comanda as ações. Os comentadores parecem unânimes em dizer que se deve desistir de encontrar personagens - dramáticas - uma vez que o autor trata as figuras como estereótipos. Tal observação pode representar importante indicação para o iluminador, uma vez que ele tem instrumental técnico para dar um caráter bidimensional ou, como se diz no teatro, para "chapar" as figuras, ainda que posicionar o spotlight ao centro para iluminar as três cabeças não seja a melhor decisão, no que se refere ao resultado proposto, pois, ao atingir, no sentido ascendente e principalmente de modo predominante, um dos lados do rosto, a luz pode acentuar volumes.

Nos diversos comentários acerca da luz em Play, o spotlight já foi considerado um inquisidor, o próprio Deus, ou até o demônio. Uma vez que a atuação da luz é determinada pelo dramaturgo e integrada a relações explícitas com as figuras que falam, sua participação pode tornar-se óbvia. A função de inquisidor pode ser ligada ao dramaturgo que a definiu e até identificada com o espectador (LAWLEY, 
1983), dado o lugar que este último ocupa como destinatário final das palavras proferidas pelas cabeças imóveis. A luz, então, ganha notoriedade em Play. Por outro lado, pode-se argumentar que Beckett cometeu um grave crime levando a circunstâncias extremas o "textocentrismo" já mencionado aqui. Ou seja, ele impôs que mesmo depois da sua morte, as imagens de uma montagem obedeçam a ordens explicitamente registradas no texto.

No entanto, há outro aspecto da questão que pode provocar um iluminador atento: mais do que uma rubrica reguladora, a primeira fala - proferida simultaneamente por todas as figuras em cena - faz sucessivas referências à escuridão, ou trevas, e à sombra. Tratando-se de uma peça onde a luz é integrada de modo tão direto à situação a ponto de ter se transformado em alvo de inúmeros comentários é importante registrar que a sombra é invocada, desde o seu início:

Sim, estranho, o melhor é a escuridão, quanto mais escuro pior, então tudo bem, | agora, mas virá, virá o tempo, a coisa está lá, você | verá, sai, mantenha-se longe de mim, tudo escuro, tudo parado, por toda parte, eliminado - | Sim, talvez, uma sombra se foi, eu suponho, alguns podem dizer, coitada, uma | sombra se foi, apenas uma sombra, na cabeça - [risada selvagem fraca] apenas uma sombra, | mas eu duvido, eu duvido, não realmente, eu estou bem, ainda bem, faço | o melhor, tudo o que posso - | Sim, a paz, um assumiu, tudo, toda a dor, toda como se... nunca foi, | ele virá - [Soluço.] - perdão, não há sentido nisso, oh eu sei... não | obstante, a paz, alguém assumiu... Quero dizer... não apenas tudo, mas como | se... nunca foi. ${ }^{39}$ (BECKETT, 1984b, p. 146, tradução nossa)

Beckett usa termos como dark, darker e darkness - escuro, mais escuro e escuridão, de reconhecida ligação com a ideia de sombra. Há, pelo menos, dois termos em inglês - shade e shadow - que podem ser destacados aqui como referência à sombra, e uma vez que Beckett usa somente o primeiro na fala inicial é até possível que um especialista no estudo da língua possa apresentar observações mais específicas, pois o termo shade é por vezes relacionado ao "estado de sombra", ou a uma área não banhada pela luz, numa abordagem simbólica e diversa daquela que

39 "Yes, strange, darkness best, and the darker the worse, then all well, for | the time, but it will come, the time will come, the thing is there, you'll | see it, get off me, keep off me, all dark, all still, all over, wiped out - |Yes, perhaps, a shade gone, I suppose, some might say, poor thing, al shade gone, just a shade, in the head - [Faint wild laugh - just a shade, | but I doubt it, I doubt it, not really, I'm all right, still all right, do my | best, all I can- | Yes, peace, one assumed, all out, all the pain, all as if... never been, | it will come - [Hiccup.] - pardon, no sense in this, oh I know ... none | the less, one assumed, peace ... I mean ... not merely all over, but as if... never been." 
se refere a uma forma objetiva, como a sombra - shadow - de uma árvore, graficamente definida no ambiente.

Finalizada a primeira fala da primeira parte que ele mesmo denominou Narração (Narration), a luz é arremessada exclusivamente sobre as cabeças, fazendo tudo o mais permanecer mergulhado nas trevas. Desde então, as figuras dentro das urnas reagem à luz, que se mantém em intensidade constante, iluminando uma ou outra cabeça durante toda a primeira parte da peça, executando precisamente aquilo que o autor determinou. Observando suas indicações, pode-se presumir que a forte intensidade dos spotlights lançados na segunda fala, simultaneamente sobre as três cabeças, será mantida durante toda a Narração na qual as três figuras revelam em fatos do passado que construiu a tortura sob crua exposição à luz, culminando com a seguinte declaração de W2: "Eu fiz um pacote das coisas dele e queimei. Era novembro e a fogueira estava ardendo. Durante toda a noite, senti o odor fumegante". ${ }^{\circ 0}$ (BECKETT, 1984a, p. 158, tradução nossa)

Nada mais radical, no que se refere à exposição à luz, do que arder numa fogueira. E ateada em novembro, já muito distante das fogueiras da última noite de abril (ou primeiro dia de maio), quando o fogo celebra a bem-aventurança da primavera queimando as bruxas - na noite das Walpurgas, já comentada aqui. Meses depois, já em novembro, tardiamente, W2 decide queimar seus demônios.

Depois da queimação de demônios e fantasmas ocorre uma mudança, como se poderia presumir. Na segunda parte da peça, a Meditação (Meditation), depois do intervalo de cinco segundos que segue um black-out as figuras se dirigem à luz e emitem opiniões sobre ela, assim como sobre a situação. Já na primeira fala da Meditação, todos mencionam em uníssono o verbo mudar: "[...] Quando isso mudou". ${ }^{41}$ (BECKETT, 1984b, p. 152, tradução nossa) Uma mudança efetiva ocorreu e deve ser reconhecida pelo espectador. Como Beckett (1984b, p. 157, tradução nossa) sublinha, ao abrir a segunda parte: "[Spot apaga em W2. Black out. Cinco segundos. Spots em metade da intensidade anterior simultaneamente nas três faces. Vozes proporcionalmente em menor volume]".42

Trata-se da mais importante mudança no espetáculo. E o dramaturgo-iluminador propõe um movimento que, considerada a simplicidade, ganha qualidade radical. É a principal mudança. Mas nem por isso são evocados os costumeiros efeitos especiais, tampouco fogos de artifício, como se fosse um feriado nacio-

\footnotetext{
40 "I made a bundle of his things and burnt them. It was November and the bonfire was going. All night I smelt them smouldering."

41 "When this first change."

42 "[Spot off W2. Blackout. Five seconds. Spots half previous strength | simultaneously on three faces. Three seconds. Voices proportionately lower.]."
} 
nal. A intensidade dos instrumentos é, simplesmente, reduzida à metade. Tal simplicidade, contudo, exige do iluminador um cuidado muito especial. Não se trata de programar mecanicamente - ou acionar - os três instrumentos, usando uma redução numérica 50\% menor do que aquela anteriormente usada. Ou seja, ele precisa experimentar, julgar, controlar e decidir que intensidade demonstra visualmente uma redução de 50\%.

Mesmo que ele parta de uma decisão numérica, e registre no comando enviado à mesa de controle um numeral que expresse a metade daquele usado na primeira parte, a construção da cena deve ser o resultado do seu controle visual. E deve levar em consideração as relações entre a redução de intensidade e a temperatura de cor, uma vez que o resultado alaranjado do âmbar que pode ser produzido com tal redução é muito relevante para a imagem cênica estabelecida.

Essas variáveis devem interagir com a diferença entre as duas partes da peça. Na Meditação as cabeças fazem referências a "algo melhor", "repousante", além de relações entre trevas e paz, como na fala de M: "Para baixo, tudo para baixo, para a escuridão, a paz está chegando, eu pensei que, afinal, enfim, eu estava certo, afinal, graças a Deus, quando isso mudou". ${ }^{33}$ (BECKETT, 1984b, p. 158, tradução nossa)

A associação entre paz e escuridão pode ser importante para a leitura do iluminador. A luz intensa e dura da primeira parte foi agora reduzida e a tortura de estar exposto à luz do conhecimento que revela os demônios de cada um parece haver acabado, parece haver sido extinta na fogueira. W1, no entanto, logo em seguida exclama: "Meia-luz infernal". ${ }^{44}$ (BECKETT, 1984b, p. 152, tradução nossa) Ou seja: as figuras, agora, continuam reagindo à luz, mas comentam sua intervenção; ela passa, também, a ser objeto da situação. A intensidade reduzida não lhe subtrai, portanto, o poder de promover conhecimento. O jogo muda, mas a tortura continua.

Estaria W1 negociando: "Como eu não falo a verdade, é isso, algum dia, de alguma forma, eu posso dizer a verdade, finalmente, e então não haverá mais luz, finalmente, em nome da verdade?". ${ }^{45}$ (BECKETT, 1984b, p. 153, tradução nossa) A luz que gera a ameaça de expor provoca uma confissão que libertaria da exposição intermitente. Mesmo que as figuras pareçam ter alcançado o direito de fazer comentários sobre a luz, ela estará presente, retornando inexoravelmente, perpetuando a luta

43 "Down, all going down, into the dark, peace is coming, I thought, after all, at last, I was right, after all, thank God, when first this change."

44 "Hellish half-light."

45 "Is it that I do not tell the truth, is that it, that some day somehow I may tell the truth at last and then no more light at last, for the truth?" 
para sobreviver diante de tal condenação e confirmando as cabeças como vítimas da luz, da exposição, da revelação. À luz é dada uma força brutal e violenta: "Saia de mim. Saia de mim". ${ }^{46}$ (BECKETT, 1984b, p. 153, tradução nossa)

A sucessão de imagens cênicas em Play resulta da reação das figuras à luz, numa pulsação precisamente concebida e projetada pela dramaturgia. O que difere muito de uma situação na qual alguém tenciona elogiar o iluminador e exclama que "sua luz", em determinada peça é uma "personagem", como se isso conferisse ao seu trabalho uma posição de destaque dentro da hierarquia teatral. Tal elogio parece, no entanto, dispensável uma vez que a luz não precisa ser reconhecida como personagem para ganhar importância. Na verdade, seu papel se cumpre quando somente ela torna teatralmente plausível e possível uma personagem na sua condição de corpo, quando ela estabelece os ambientes povoados por esse corpo, quando define as atmosferas originadas nos desejos do trinômio corpo-mente-alma e instala as imagens cênicas.

Elaborar um projeto que contemple tais exigências é uma tarefa que exige precisão. Se o iluminador acompanhar o rigor exigido por Beckett, cada didascália indica muitas decisões referentes a ângulo, posição, distância, cor, intensidade, lente, lâmpada, dentre muitas outras, que devem ser registradas em planilhas e desenhos técnicos, cuja aparência já assustaria qualquer neófito. Um projeto, contudo, responderia à expectativa do autor, no que se refere ao controle e à precisão.

Pode-se dizer que Beckett foi o responsável por estabelecer a maior comoção e o maior reconhecimento da luz como aspecto ativo na cena desde que se constatou a importância da eletricidade na luz teatral ao final do século XIX. Foi necessário, portanto, que um dramaturgo a ela emprestasse uma função mecanicamente objetiva em seu teatro para que teoria e/ou crítica notassem sua presença, como se ela estivesse ausente do teatro até então, ou fosse acessório sem motivo para menção. Grave engano, como venho tentando comentar aqui.

\section{BOB WILSON E O ESPETÁCULO COMO TEXTO TOTAL}

Mais tarde, ainda no século XX, outro artista trataria a luz com destaque, ao elaborar espetáculos apontados por comentadores como acontecimentos repletos de qualidades cerimoniais. Trata-se de Robert (Bob) Wilson, celebrado artista norte-americano nascido em 1941, reconhecido como diretor, coreógrafo, escul-

46 "Get off me. Get off me." 
tor, pintor, dramaturgo e lighting designer, em atividade desde o final da década de 1960. Suas montagens foram destacadas como importantes manifestações no ambiente do teatro pós-dramático e qualificadas pelas primeiras críticas como "cultos realizados por estranhas pessoas". O próprio Hans-Thies Lehmann (2006, p. 69, tradução nossa) define a natureza cerimonial do teatro pós-dramático, aproximando-se de Wilson:

O que se denomina cerimônia, como um momento do teatro pós-dramático é, portanto, todo o espectro de movimentos e processos que não têm referentes, mas que são apresentados com precisão aguda; eventos de 'comunalidade' [compartilhamento] peculiarmente formalizada, construções ritmomusicais ou construtos de desenvolvimento visual-arquitetônico; formas para-rituais, bem como a cerimônia (muitas vezes profundamente obscura) do corpo e da presença; a enfaticamente ou monumentalmente acentuada ostentação da apresentação. ${ }^{47}$

Como se pode constatar, ele se refere a um espectro muito amplo que tem na visualidade uma linha mestra transversal. As competências e habilidades dos responsáveis por essas manifestações ocupam campos do conhecimento que ganhavam espaço, ampliavam e até descartavam certos pressupostos do então chamado antigo teatro dramático.

Aristóteles podia, afinal, descansar em paz levando consigo o mythos e seus pares - a fábula, o enredo, a ação, os desejos humanos, a interpretação, a mimesis figurativa - e assim por diante. Por outro lado, o artista envolvido com essa mencionada "dinâmica cênica" necessitava incorporar uma elaborada educação visual ou estaria apenas especulando na cena ao fazer uma aplicação radicalmente exclusiva da intuição, produzindo seu novo teatro através do acaso. As instituições de ensino envolvidas com o novo teatro obrigar-se-iam a incluir no seu trato acadêmico-pedagógico a efetivação da práxis visual (elaboração, planejamento e efetivação de objetos visualmente - esteticamente - competentes) para evitar que, mesmo com todo o conhecimento filosófico-científico com o qual o artista em processo de aprendizado era obrigado a se familiarizar, ele fosse levado a resolver

\footnotetext{
47 "What is meant by ceremony as a moment of postdramatic theatre is thus the whole spectrum of movements and processes that have no referent but are presented with heightened precision; events of peculiarly formalized communality; musical-rhythmic or visualarchitectonic constructs of development; para-ritual forms, as well as the (often deeply black) ceremony of the body and of presence; the emphatically or monumentally accentuated ostentation of the presentation."
} 
seus problemas visuais com a genialidade e/ou, na sua ausência, com a mencionada intuição.

Quando se trata daquele momento pós-dramático, penso que caberia refletir sobre as demandas apresentadas ao ator de um teatro sem personagem; ao diretor, que lidaria com "situações" nas quais os desejos das personagens não estariam em discussão, através da ação; ao cenógrafo, que criaria arranjos cênicos sem o compromisso com a antiga noção de ambiente da chamada "dinâmica dramática"; ao figurinista, cujos objetos podiam ter mais valor para o arranjo cênico do que aquele ser humano que o portaria, antigamente denominado ator; ao lighting designer, que cumpriria sua função criando momentos visuais autônomos, sem, necessariamente, qualquer relação com qualquer ambiente humano, concentrando-se apenas no lugar e momento onde o evento ocorreria. Logo a noção de evento ou acontecimento incorporaria hierarquicamente o termo "movimento" para questionar a antiga compreensão de ação, dramática, que exigia uma personagem. Tratava-se de um novo artista.

Bob Wilson, cuja formação se iniciou na administração de negócios (Universidade do Texas, de 1959 a 1962), passou depois pela arquitetura (no Instituto Pratt, em Nova York, 1965) e pela pintura, tendo estudado com George J. McNeil. Reconhecido por Lehmann como um dos mais importantes nomes do novo teatro, ele iniciou seu trabalho por volta de 1968 quando fundou a companhia experimental School of Byrds Byrd Hoffman, cujo nome era uma homenagem à dançarina Byrd Hoffman com a qual ele teve contato ainda adolescente e o marcou de modo significativo, até ajudando-o na solução de problemas da fala.

Na opinião de Lehmann (2006), as experimentações de Wilson investem na "desierarquização" dos meios teatrais ligados a figuras psicologicamente elaboradas ou mesmo aquelas individualmente locadas em um contexto coerente. Suas figuras são apresentadas como emblemas incompreensíveis e a ostentação da aparência determina seu significado, dispensando interrogações e, consequentemente, a busca de respostas. Os atores que dividem o palco raramente (ou nunca) ingressam em qualquer contexto de interação e a luz é aplicada para criar descontinuidade ou eliminar a homogeneidade do espaço. A cena se constitui de citações do armazenamento humano de imagens que são apresentadas como danças de imagens com qualidade neomítica, incorporando os mitos - o imaginário mítico - como imagens nas quais a ação aparece apenas como fantasias virtuais. Como define o próprio Lehmann (2006, p. 79, tradução nossa): “[...] no teatro de Robert Wilson, o espaço é dividido 'em tiras' paralelas ao proscênio, de modo que as ações 
acontecem em diferentes profundidades do palco e podem ser sintetizadas pelo espectador ou podem ser lidas como 'paralelogramos', por assim dizer". ${ }^{4}$

Lehmann (2006) diz, ainda, que o teatro de Bob Wilson cria um tempo do olhar e, numa das inúmeras explicações e definições, ele usa a expressão - já aplicada desde Louis Hartmann e John Alton, "pintar com luz" -, além de indicar uma importante interpretação do novo teatro ao afirmar que os seres humanos são transformados em esculturas gestuais. Na verdade, essa observação deveria ser um alerta para todo iluminador: uma das mais importantes funções do lighting design, na sua condição de aspecto definidor da visualidade da cena é tratar o ator - mesmo naquilo que Lehmann compreende como o antigo, ou velho teatro dramático - como um corpo, obstáculo ou suporte, com o qual a luz interage. Caso contrário, o iluminador estará abrindo mão de compreendê-lo como uma decisiva presença tridimensional em cena. Ou seja, mesmo uma grande estrela representando Hedda Gabler em uma montagem realista, deve ser compreendida, também, como um corpo em cena.

A acentuação da imagem corporificada em cena é determinante no teatro de Lehmann e exige do iluminador enorme competência no estabelecimento de respostas visuais para tais demandas. Uma vez que os resultados são cuidadosamente concebidos e exaustivamente planejados, tanto a familiaridade com instrumentos, acessórios e sistemas de controle, quanto o aprofundado conhecimento das artes visuais, da estética, será indispensável para essa extrema e radical elaboração do espaço teatral. Independentemente da opinião de um ou outro crítico - contra ou a favor - interessa uma indagação: teríamos a obra de Wilson para discutir, se a ele fossem disponibilizados o equipamento e os prazos de que dispõe a maioria dos iluminadores brasileiros?

\subsection{PSYCHOSIS: FRAGMENTOS DE VISUALIDADE}

Na compreensão do próprio Lehmann, a dinâmica cênica radical do teatro pós-dramático pode incorporar textos que interajam com tais proposições, Como foi esclarecido no início do presente capítulo, a abordagem em curso segue a própria indicação do texto 4.48 psychosis, de Sarah Kane, ${ }^{49}$ com o objetivo de identificar

48 "[...] Wilson's space is divided 'into stripes' parallel to the apron of the stage, so that actions taking place in different depths of the stage can either be synthesized by the spectator or be read as 'parallelograms', so to speak." 49 Sarah Kane suicidou-se poucos meses depois de concluir esse texto, mencionado por alguns comentadores como uma provável nota de suicídio. 
seus traços visuais-imagéticos. Afaste-se o interesse de classificar, enquadrar ou julgar o texto de Kane a partir de abordagens da possível enfermidade mental, que pode ter contribuído para sua elaboração, posto que tal enfoque exigiria autoridade particular. O texto foi lido como desafio para uma proposição de visualidade na cena sem a pretensão de aprofundamento da análise, no trabalho em curso, uma vez que isso tornaria esta seção muito extensa. Serão mencionadas provocações visuais latentes buscando aproximação com a hipótese que se refere à presença da visualidade na gênese do pensamento cênico. Pode-se até argumentar que a construção 4.48 psychosis não determina a intenção explícita de produzir um texto teatral, que não há uma construção convencional de diálogo ou identificação de personagens que falam; nada impede que ele seja compreendido como um monólogo; nada o conecta à estrutura dramático-realista reconhecida, na qual se espera a elaboração lógica de um ambiente onde ocorre a ação.

Por outro lado, mesmo de modo intuitivo e sem qualquer fundamentação de natureza científico-médica apreende-se no texto um modo de falar controlado por um autor para comunicar e expressar certo desarranjo interno no discurso: como se a aparência de caos fosse sustentada por um ordenamento interno da obra que o procura expressar e comunicar. Deixa de interessar ao estudo em curso o ponto no qual se encontram as fronteiras entre uma possível enfermidade mental de Kane e suas escolhas de artista que definiram a elaboração do texto. Ainda que, quando se considera a fala que ela põe em cena - a voz de alguém em desequilíbrio, em sofrimento, sentindo culpa, alimentando relações com a morte e fazendo pedidos de socorro - é possível observar uma organização do discurso que demonstra interesse na verossimilhança. Aqui são apresentadas considerações de um leitor movido por uma compreensão visual do texto, sem a profundidade de um teórico, crítico ou diretor, e muito menos de um psicanalista ou psiquiatra. Sarah Kane (2001, p. 206-207, tradução nossa) escreveu:

Eu estou triste | Eu sinto que o futuro é sem esperança e que as coisas não podem melhorar | Eu estou de saco cheio e insatisfeito(a) com tudo | Eu sou um completo fracasso como pessoa | Eu sou culpado(a), estou sendo punido(a) | Eu gostaria de me matar | Eu costumava conseguir chorar, mas agora estou além das lágrimas | Eu perdi o interesse em outras pessoas | Eu não consigo tomar decisões | Eu não consigo comer | Eu não consigo dormir | Eu não consigo pensar | Eu não consigo derrotar minha solidão, meu medo, meu desgosto | Eu estou gorda | Eu não consigo escrever | Eu não consigo amar | Meu irmão está morrendo, meu amor está morrendo, estou matando os dois | Eu avanço em direção à minha morte | Eu estou aterrorizado(a) 
com a medicação | Eu não consigo fazer amor | Eu não consigo foder | Eu não consigo ficar sozinho(a) | Eu não consigo ficar com outras pessoas | Meus quadris são muito grandes | Eu não gosto da minha genitália [.....$^{50}$

Um conjunto de falas, ou fala única, que pode resumir a apresentação que, no drama realista, é distribuída na didascália de abertura e/ou no decorrer da ação, mesmo que uma personagem do realismo não se declare de modo tão explícito.

Ela pode estar triste, pode estar avançando para a sua própria morte, e não pode se revelar através da própria escrita; mas Sarah Kane, a autora, foi capaz de escrever o texto, apresentando uma situação teatral que pode representar um considerável desafio e se transformar numa armadilha para o iluminador, ou seja: a figura em cena pode remeter a uma pessoa que pede socorro encontrando-se, portanto, em algum lugar e tempo. Na intenção de distanciar a obra do contexto "dramático-realista", o lugar e o tempo devem ser aqueles nos quais a ação acontece, na hora em que o evento acontece, onde e quando um artista (ou grupo de artistas) decide trabalhar com o texto de Sarah Kane. O trecho acima citado parece indicar uma exposição crua da pessoa que descreve a si mesma. Efeitos espetaculares podem mascarar ou teatralizar negativamente, destruindo essa espécie de amostragem que se revela um pedido de socorro: "Eu não quero morrer [...] Eu não quero viver". ${ }^{51}$ (KANE, 2001, p. 207, tradução nossa)

Já no título, o termo "psicose" é acompanhado pelo número " 4.48 ". Sabe-se que a autora acordava a essa hora toda madrugada e que via, nesse instante de trevas, grandes lampejos de claridade que afastavam os confusos sentimentos da psicose. Ainda assim, cabe perguntar por que ela escolheu tal título para a obra. O termo "psicose" ganha destaque no texto propriamente dito (sem a interferência de outras interpretações, inclusive daquelas voltadas para abordagens não cênicas da questão), através do isolamento, já que não se repete, explicitamente, em nenhum outro momento. No que se refere à visualidade, o isolamento e o posicionamento são indícios importantes para a composição, para a imagem. Por outro lado, a compreensão do termo

\footnotetext{
50 "I am sad | I feel that the future is hopeless and that things cannot improve | I am bored and dissatisfied with everything | I am a complete failure as a person | I am guilty, I am being punished | I would like to kill myself | I used to be able to cry but now I am beyond tears | I have lost interest in other people | I can't make decisions | I can't eat | I can't sleep | I can't think | I cannot overcome my loneliness, my fear, my disgust | I am fat | I cannot write | I cannot love | My brother is dying, my lover is dying, I am killing them both | I am charging towards my death | I am terrified of medication I cannot make love | I cannot fuck | I cannot be alone | I cannot be with others | My hips are too big | I dislike my genitals [...]."

51 "I do not want to die [...] I do not want to die."
} 
psicose - ainda que rasa e não científica - pode se referir a uma condição geral que revela alto grau de desajuste ao cotidiano, estabelecido na ação.

O texto-imagem "4.48" aparece logo depois da apresentação citada acima: "Às 4.48 | quando o desespero visita | eu deverei me enforcar | ao som da respiração do meu [da minha] amante [...]. ${ }^{52}$ (KANE, 2001, p. 207, tradução nossa) Simule-se um exercício no qual serão lidas essas palavras logo depois do título, considerando-se um tempo (e um lugar) no qual a ação foi instalada, um momento que antecede aquele das $4 \mathrm{~h} 48$, antes da visita do desespero, diante da presença do (a) amante. Ou, quem sabe, a ação esteja se iniciando precisamente às 4 h48. Por que 4 h 48 e por que 4 h 48 reaparece? O texto traz: "Depois das 4 h 48 eu não devo mais falar [...]" visita por uma hora e doze minutos eu tenho controle da minha mente." (KANE, 2001, p. 229, tradução nossa); e ainda: "Às 4h48 / Eu dormirei [...]".54 (KANE, 2001, p. 233, tradução nossa)

Então, o tempo flui ou permanece... congelado? O controle da mente relacionado ao preciso momento, 4h48, levará ao silêncio, ao sono, à morte? Kane pode haver sugerido na evocação do título e ao longo do texto, uma provocação temporal que pode ser incorporada ao tratamento cênico. Não necessariamente no sentido de tempo linear ou traços realistas. Ou seja, podem estar sugeridos movimentos na luz que construam visualmente esses momentos nos quais se considera o tempo e suas variações de andamento, de ritmo e de pulsação, no sentido musical. Sem incluir compromissos com a representação figurativa, mas com extrema atenção e acentuação da pessoa que fala, como corpo e como imagem. Corpo que atua como meio na construção da imagem. Os ângulos referentes ao posicionamento das fontes de luz podem gerar sombras que determinem visualmente relações da pessoa que "fala" (age) com o ambiente. Como uma sombra que projete firmemente a cabeça da pessoa que fala (age), sugerindo atenção no ponto onde ela (a sombra) toca. Ou todo o corpo pode ter sua sombra diluída, sugerindo destituição de limites lógicos, desvanecendo-se.

Esses são alguns aspectos da abordagem visual que podem promover consistência artística ao tratamento concebido por um lighting designer. As observações do parágrafo acima referem-se apenas a um instrumento (refletor). E se outros forem adicionados, multiplicando as sombras? No que se refere a cores e texturas, que relações podem ser estabelecidas? Não se pretende aqui esgotar possibilida-

\footnotetext{
52 "At 4.48 | when depression visits | I shall hang myself | to the sound of my lover's breathing [...]."

53 "After 4.48 I shall not speak again."

54 "At 4.48 I shall sleep."
} 
des, pois não parece possível, tampouco necessária, a enumeração completa de caminhos prováveis de abordagem visual de qualquer que seja a obra. No entanto, é recomendável visitar outros momentos para o fortalecimento da presente argumentação.

O texto é iniciado com uma referência temporal, de duração, presença e permanência. Já na abertura, a autora indica:

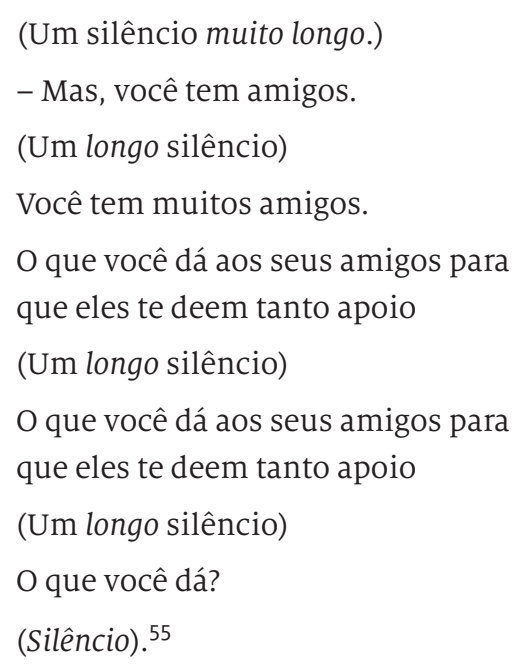

Ela opera com extrema generosidade, uma vez que o leitor tem absoluta liberdade para determinar a duração referente a qualidades como silêncio "longo" ou "muito longo". Que extensão está sugerida, ou determinada, pelo termo "silêncio"? E mais: é possível compreender essa indicação como um silêncio vocal, mas não, necessariamente, silêncio gestual e/ou de movimento (corporal). Se o iluminador estiver trabalhando com um diretor que estudou Lehmann ou assistiu Bob Wilson, haverá grande possibilidade de surgir, no intercâmbio de opiniões, o que Lehmann (2006, p. 164, tradução nossa) diz sobre o problema:

Ele [o corpo] não pode ser reduzido a um mero efeito visual externo. Quando o movimento físico é executado muito lentamente, de tal forma que o tempo do seu desenvolvimento em si parece ser ampliado, como através de uma lente de aumento, o próprio corpo é, inevitavelmente, exposto na sua concreção. Ele está sendo ampliado, como através da lente de um observador

55 "(A very long silence.) | - But you have friends. | (A long silence.) | You have a lot of friends. | What do you offer your friends to make them so supportive? | (A long silence.) | What do you offer your friends to make them so supportive? | (A long silence.) | What do you offer? | (Silence.)" 
e é, simultaneamente, um 'recorte' do espaço-tempo contínuo, como um objeto de arte. Ao mesmo tempo, o aparelho motor é alienado: cada ação (a pé, de pé, levantando-se e sentando-se) permanece reconhecível, mas é alterada, como nunca se viu..$^{56}$

O corpo tornado radicalmente concreto pode revelar mais do que a mera aparência visível externa da pessoa em cena. Ele pode expor a dilaceração interna do ser. E a luz tem um papel em tal contexto que só a ela pertence: é o seu domínio. O momento mencionado da cena, de duração inicialmente desconhecida, pode representar excelente tema de pesquisa para o designer. Uma pesquisa diferente daquela que se processa em busca de respostas para problemas teóricos. Uma investigação em busca da imagem, da sucessão de imagens inscritas dinamicamente no tempo ficcional-cênico. Um problema específico de design. Não há "coelhos a serem retirados de cartolas". Os truques com fumaça podem não ter qualquer valor na cena. Gobos ${ }^{57}$ digitais que pululam, circulam ou esperneiam podem não contribuir. As cores que estão "sendo muito usadas" podem até continuar sendo usadas, mas, em outras instâncias. Ou seja: não há respostas prontas.

O acontecimento cênico, para evitar o termo espetáculo, projeta-se para além do seu momento inicial. Pode-se apreender, na situação criada por Kane (2001), duas presenças: uma que pergunta e outra, que não responde, além do bystander (aquele que observa), que pode ser compreendido como testemunha, alguém presente (um terceiro), ou um espectador. E se o momento de abertura for tratado como um diálogo - mesmo somente com um ator -, pergunte-se onde e quando ele se passa. Um leitor regular do antigo teatro, ao qual esse novo teatro se opunha, perguntaria: onde se passa tal "diálogo"? Seguindo adiante no texto, observa-se que a autora tomou uma decisão importante, uma decisão visual, gráfica, tratando seu texto como uma imagem, também: depois do diálogo inicial, ela marca a página com um sinal, uma linha, um traço que parece indicar fim de um fragmento e início de outro, o que pode sugerir diversidade de lugares e tempos.

Em que lugar se encontra a pessoa que, na abertura, permanece em silêncio? A seguir, no texto propriamente dito, e separado pelo traço incisivamente grafado,

\footnotetext{
56 "It cannot be reduced to a merely external visual effect. When physical movement is slowed down to such an extent that the time of its development itself seems to be enlarged as through a magnifying glass, the body itself is inevitably exposed in its concreteness. It is being zoomed in on as through the lens of an observer and is simultaneously 'cut out' of the time-space continuum as an art object. At the same time, the motor apparatus is alienated: every action (walking, standing, getting up and sitting down) remains recognizable but is changed, as never seen." 57 Padrões gráficos projetados sobre a cena. Podem resultar de aplicações de acessórios adicionados aos instrumentos do tipo elipsoidal, ou programados nos chamados instrumentos de luz, "inteligentes" [moving light].
} 
vê-se um desdobramento de imagens que mixam a descrição figurativa de um lugar, com indícios de fantasia: ${ }^{8}$

Uma consciência consolidada reside num salão de banquete escurecido perto do teto de uma mente cujo chão se move como dez mil baratas quando um facho de luz penetra enquanto todos os pensamentos se unem num instante de harmonia corpo não mais repelente enquanto as baratas contêm uma verdade que ninguém nunca pronuncia [...]. ${ }^{59}$ (KANE, 2001, p. 205, tradução nossa)

O iluminador encontrará nesse fragmento muitas questões, possibilidades e provocações. A pessoa que o construiu esteve mergulhada em um modo visual de pensar; os aspectos poéticos da construção literária podem se confundir (mixar) com as imagens latentes no texto; difícil determinar, e talvez não seja importante, onde está o acento ou relevância: na elaboração poética ou nas imagens. Há um salão de banquete escurecido, o que já representa uma indicação prenhe de provocações visuais. O salão, no entanto, traz uma particularidade: ele se localiza nas proximidades do teto de uma mente, cujo piso lembra o movimento de 10 mil baratas. Por que baratas? O sujeito-narrador que descreve o ambiente terá medo de baratas? Quem gosta de baratas e por quê? De todo modo, em seguida o ambiente escurecido é invadido por um facho de luz que liga pensamento, harmonia, corpo, baratas e "verdade". Ainda que escurecido o salão, já era possível ver o movimento das baratas e identificar o próprio salão. A luz, no entanto, rasga a escuridão (ou penumbra), no momento em que os pensamentos são interligados na harmonia. Pragas, trevas, luz e revelação; soa bíblico, místico e até mítico.

E as indagações se avolumam. Se num espetáculo provocado pelo texto de Kane for efetuada a tentativa de fisicalizar essa mente particular na qual se instalaria o movimento de baratas respondendo à provocação originada pelo diálogo que antecede a mencionada descrição, o grau de fantasia estabelecido por uma imagem de tal natureza pode levar o espectador a incorporar plausibilidade em qualquer ação (incluindo palavras, diálogos) que ali seja apresentada ou representada, pois o traço de união será a fantasia, que atuará como linha mestra de unidade

58 Como na psicologia, de acordo com o Dicionário Houaiss: "atividade representativa com certo grau de criação, cujos conteúdos são determinados por ideias súbitas e por lembranças modificadas ou enfraquecidas de objetos, acontecimentos e situações, inclusive sua significação emocional."

59 "a consolidated consciousness resides in a darkened banqueting hall near the ceiling of a mind whose floor shifts as ten thousand cockroaches when a shaft of light enters as all thoughts unite in an instant of accord body no longer expellent as the cockroaches comprise a truth which no one ever utters [...]." 
no discurso, tornando-se uma espécie de orientação para o jogo proposto pelo espetáculo, ou pela cena. Daí, tudo aquilo que ocorrer será validado pela liberdade do fantástico e de elaboração. Ou seja, em um lugar assim, tudo pode acontecer. No entanto, um diretor pode também compreender no texto em si (fragmentado), o contraste entre a situação e o julgamento, o que poderá lhe provocar tratamento diferenciado que assinale cada um dos "momentos-fragmento", configurando estados da pessoa apresentada e/ou representada.

Tanto esses momentos-fragmento quanto os estados da pessoa podem ser ligados aos estados de imagem mencionados por Lehmann (2006, p. 68, tradução nossa) quando ele relaciona o teatro com a elaboração de imagens numa pintura cujo processo de pintar é invisível para o observador: "O teatro aqui mostrava 'menos uma sucessão, um desenvolvimento de uma história [e] mais um envolvimento de estados internos e externos"'. ${ }^{\circ}$ Às 4 h4 48 a depressão visita. (KANE, 2001) Nessa mesma hora, entretanto, a sanidade aparece. (KANE, 2001) É possível estabelecer um contraste entre os momentos (estados) nos quais o portador da depressão incorpora maneiras diferentes de pensar sobre as coisas e sobre si mesmo e aqueles nos quais a mesma pessoa se comporta, como no instante da segunda ocorrência das $4 \mathrm{~h} 48$, sob as regras da "sanidade".

Afinal, há um momento no qual se lê: "Estou vendo coisas | Estou ouvindo coisas | Eu não sei quem sou [...]" ${ }^{61}$ (KANE, 2001, p. 225, tradução nossa) Aqui a autora pode estar apontando para imagens inscritas ao longo do texto. E há muitas, além daquelas já mencionadas, que invocam o teto de uma mente: "Eu me afogarei na ansiedade [disforia, ou enfermidade, em grego] | na fria e negra lagoa de mim mesma | o fosso da minha mente imaterial [...]".62 (KANE, 2001, p. 213, tradução nossa) Ou seja, para compreender o que se pode ler e vislumbrar naquilo que está inserido em "estou vendo coisas", vale começar com uma leitura que sublinhe essas imagens mentais, e enfrentar o desafio de incorporar, como exemplo, essa lagoa negra e fria, alojada no fosso de uma mente destituída de matéria.

Ainda, e não menos importante, devem-se observar as dezenas de referências específicas à luz presentes no texto, como já foi dito na referência à primeira rubrica, estendendo a outros termos, como escuridão, visão, olho, vista, noite, dia, claridade e hora. Quando se considera particularmente o substantivo luz, certos

\footnotetext{
60 "The theatre here showed "less a succession, a development of a story, more an involvement of inner and outer states."

61 "I'm seeing things | I'm hearing things | I don't know who I am."

62 "I will drown in dysphoria | in the cold black pond of myself | the pit of my immaterial mind [...]."
} 
períodos chamam a atenção: "Lembre-se da luz e acredite na luz" (KANE, 2001, p. 206, tradução nossa); "Alçapão é aberto | Luz crua". 64 (KANE, 2001, p. 225, tradução nossa) Tais invocações da luz estabelecem ligações com fé e verdade, mas também, com encarceramento e violência, acentuando situações que se repetem durante todo o texto. Vale também ressaltar as muitas referências à Bíblia, das quais cito as que se seguem, para indicar uma trilha que pode aproximar o leitor das imagens que moveram a autora: "[...] Isso deve passar [...]". ${ }^{5}$ (KANE, 2001, p. 228, tradução nossa) Há outro exemplo, evocando também trevas, escuridão: "[...] vejam a luz do desespero | o brilho da angústia | e sereis lançados às trevas [...]". ${ }^{66}$ (KANE, 2001, p. 228, tradução nossa)

Há outros momentos de grande provocação visual para um iluminador que leve em consideração 4 h48 psycosis, de Sarah Kane (2001, p. 228, tradução nossa): "Eu tive visões de Deus". ${ }^{67}$ Deus, cuja invocação se repete por sete vezes, número também presente nas menções a testes aos quais são submetidos pacientes com enfermidades mentais, para observar níveis de concentração e memória.

Como se não bastasse, caberia sublinhar o modo visual da construção do texto, a disposição das palavras como interferências visuais na página em si, como se vê no exemplo abaixo, mantida a organização visual do texto impresso, para aproximar o leitor dessa compreensão.

Hatch opens

Stark light

A table two chairs and no windows

Here I am

and there is my body

dancing on glass

(KANE, 2001, p. 230)

\footnotetext{
63 "Remember the light and believe the light."

64 "Hatch opens | Stark light."

65 "[...] it shall come to pass [...], que se refere a Zacarias 14:6: "And it shall come to pass in that day, that the light shall not be clear, nor dark" [E isso acontecerá naquele dia, no qual a luz não será clara, nem escura].

66 "[...] behold the light of despair | the glare of anguish | and ye shall be driven to darkness [...]", que aparece no Antigo Testamento, Isaías 8:22: "And they shall look unto the earth; and behold trouble and darkness, dimness of anguish; and they shall be driven to darkness." [E olharão para a terra, e verão angústia e escuridão, sombras da aflição, e serão lançados às trevas].

67 "I saw visions of God."
} 
A tradução [nossa] pode aparecer assim:

\author{
Alçapão é aberto \\ Luz crua \\ Uma mesa duas cadeiras e nenhuma janela \\ Aqui estou eu \\ e aqui está meu corpo \\ dançando sobre vidro
}

Dada tal situação (ou acontecimentos que norteiam a obra), as características desse fragmento como texto elaborado para expressar e/ou comunicar a psicose misturam-se à elaboração visual desse mesmo contexto: o "alçapão" (uma porta?) leva a um ambiente duramente exposto pela crueza da iluminação. Isoladas, mesa e cadeiras; isolados aqueles que as ocuparão, já que o mundo exterior é deixado de fora, pois não há janelas. Para o narrador que tem voz nesse instante, a vida incorpora a sensação de um corpo disposto (que dança - note-se o intervalo, espaço vazio ou silêncio expresso graficamente no texto) em uma superfície que pode ser fria, escorregadia, cortante, finamente perigosa, e assim por diante. Insegurança, desespero, incerteza, solidão, dor e angústia reunidos em um pequeno fragmento, um momento breve, mas prenhe de visualidade.

Essa breve abordagem refere-se exclusivamente ao texto e dá uma pequena mostra da sua capacidade provocativa. Na criação de um espetáculo, essa categoria de observações - estendida para a totalidade do texto - teria papel importante na elaboração do ponto de vista de um designer, cujo confronto com aquele do diretor poderia resultar em contribuição para um projeto de luz. Pode-se observar, portanto, a possibilidade de estabelecimento, tanto dos ambientes nos quais as situações dialógicas acontecem, quanto daqueles nos quais os diversos fragmentos se passam. Afinal, Kane perpassou o texto com diversas instâncias de luz, abrindo muitas possibilidades para a abordagem de presenças da visualidade. A realização de espetáculos que apliquem o seu texto, na totalidade ou em quaisquer fragmentos, dá aos artistas envolvidos a chance de incorporação dessa presença.

Observa-se, por conseguinte, que desde as considerações críticas de HansThies Lehmann, passando pelo trabalho de um diretor que ele menciona como um expoente do seu teatro pós-dramático, Robert (Bob) Wilson, e finalizando com o texto de uma autora que há pouco gerou um burburinho como extrema novidade, Sarah Kane, cuja obra foi referendada pelo pensamento teatral de Lehmann, a interação entre cena e visualidade confirmou-se intensa. 


\section{BERTOLT BRECHT E A LUZ DO TEATRO CIENTÍFICO}

Se o teatro pós-dramático de Lehmann incorporava uma espécie de requalificação visual da palavra falada, em Bertolt Brecht o drama perdeu sua hegemonia para a qualidade narrativa do que ele compreendia como "teatro épico", operando também uma nova compreensão da palavra no teatro. Brecht confrontou a teoria apresentada por Goethe e Schiller, no que se refere à separação entre a poesia épica e a dramática. A proposição do jovem dramaturgo e diretor repercutiu amplamente no teatro brasileiro, na segunda metade do século XX.

O que Brecht denominou teatro da era científica incluía uma atitude crítica na qual o espetáculo contava uma história incorporando a forte tendência de acentuar a presença do palco, dos seus aparatos, mostrando alternadamente ator e personagem em cena, levando o espectador a tomar ciência de que ocupava uma posição na plateia de um teatro, configurando um conjunto de iniciativas que desconstruíam o caráter ilusionista do realismo. Posicionado "do lado de fora da cena", o espectador tornava-se capaz de chegar às suas próprias conclusões acerca daquilo que seria apresentado na cena, através da observação crítica. Martin Esslin (1980) aponta uma analogia entre o combate ao realismo no teatro e a reação dos pintores impressionistas à representação figurativa presente na chamada pintura acadêmica da época. Assim como nas telas o palco parecia ter alcançado seus limites, na tentativa de reproduzir a realidade, tornando-se inevitável a busca de outros caminhos.

Essa busca se evidenciou na obra de Bertolt Brecht, da qual dois aspectos estão aqui destacados: em primeiro lugar, o seu Pequeno organon para o teatro (Kleines organon für das theater), escrito em 1948, no qual ele apresentou o pensamento que sustentava o seu teatro épico ou científico, capaz de instruir e entreter; em seguida, será abordado seu poema A iluminação (Die beleuchtung), raramente mencionado no Brasil. A tradução do trabalho de Martin Esslin, Brecht: dos males o menor (Brecht: a choice of evils: a critical study of the man, his work and his opinions) traz parte do poema, sem grande repercussão entre nós.

Outros aspectos importantes das reflexões apresentadas em $O$ pequeno organon para o teatro foram exaustivamente discutidos. Acentue-se a compreensão de Brecht, quando ele se refere ao teatro como a apresentação de relações entre seres humanos e, também, entre seres humanos e deuses. Aí se confirmava, portanto, a necessidade de um lugar onde esses acontecimentos deviam ocorrer, cabendo observar no texto teórico traços para a orientação do tratamento cênico desse lugar, ou lugares. Além disso, ele acreditava que o novo teatro deveria se 
afastar dos pressupostos do Naturalismo, voltando-se para “[...] representações cientificamente exatas [...]”. ${ }^{68}$ (BRECHT apud WILLET, 1977, p. 179, tradução nossa) Desse modo, o teatro precisava mostrar a realidade com precisão científica, o que determinou a inclusão do seu teatro épico ou científico na presente investigação. Curiosamente, pode-se até dizer que o Naturalismo de Zola incorpora certa curiosidade científica.

Em Brecht, contudo, a natureza política do novo teatro configurava uma resposta crítica ao drama: "Quanto tempo mais nossas almas manterão os nossos corpos 'genuínos' sob a capa da escuridão, para mergulhar nessas figuras oníricas no palco, para tomar parte nos crescendos e nos climaxes que a vida 'normal' nos nega?". 69 (BRECHT apud WILLET, 1977, p. 184, grifo e tradução nossos) Já se pode observar aqui o forte apelo visual da sua compreensão do teatro, anunciando a presença de tal apelo no seu combate ao "mergulho onírico". Em sua opinião, o caminho para a nova cena impunha uma nova maneira de apresentar a realidade:

Onde está o próprio homem, o homem inconfundível, vivo, não totalmente idêntico àqueles que a ele se assemelham? É claro que a sua imagem no palco deve trazê-lo à luz, e isso vai acontecer se essa contradição particular for recriada pela imagem. A imagem que dá a definição histórica irá reter algo do esboço irregular que indica traços de outros movimentos e recursos em torno da figura totalmente efetivada. ${ }^{70}$ (BRECHT apud WILLET, 1977, p. 191, tradução nossa)

Tais reflexões comprovam sua exigência de uma maneira particular de mostrar seu espetáculo épico, ou científico, que exigia uma nova imagem, indicando parcerias contundentes com a luz para determinar uma visualidade muito peculiar: "Essas imagens certamente exigem um modo de representar que vai deixar o intelecto do espectador livre e altamente móvel".71 (BRECHT apud WILLET, 1977, p. 191, tradução nossa) O ator, então, devia ser treinado para representar de um modo que permitisse a criação de imagens especialmente tratadas para alcançar um resultado específico: estimular no espectador a compreensão, provocando opiniões sobre os conflitos apresentados.

\footnotetext{
68 "[...] scientifically exact representations."

69 "How much longer are our souls, leaving our 'mere' bodies under cover of the darkness, to plunge into those dreamlike figures up on the stage, there to take part in the crescendos and climaxes which 'normal' life denies us?" 70 "Where is the man himself, the living, unmistakeable man, who is not quite identical with those identified with him? It is clear that his stage image must bring him to light, and this will come about if this particular contradiction is recreated in the image. The image that gives historical definition will retain something of the rough sketching which indicates traces of other movements and features all around the fully-worked-out figure."

71 "Such images certainly demand a way of acting which will leave the spectator's intellect free and highly mobile."
} 
Trabalhando em soluções para um tratamento visual particular, Brecht propôs uma maneira de tratar a cena que gerasse um novo "efeito": "[...] a produção dessas imagens, é baseada no 'efeito de estranhamento' [V-effect (Verfremdungseffekt)]. Uma representação que causa estranhamento é aquela que nos permite reconhecer o seu objeto, mas, ao mesmo tempo, o faz parecer estranho [causa estranheza]". ${ }^{72}$ (BRECHT apud WILLET, 1977, p. 192, tradução nossa) Essa representação exigia do ator uma performance que interagisse com os outros aspectos visuais. Sua presença em cena devia se efetivar através de escolhas precisas das atitudes, determinando uma fisicalização especial que compreendia o ator como uma imagem

O campo das atitudes adotadas pelas personagens em relação às outras é o que chamamos o âmbito do gesto. Atitude física, tom de voz e expressão facial são todos determinados por um gesto social: as personagens estão amaldiçoando, lisonjeando, instruindo as outras, e assim por diante. As atitudes que uma pessoa adota em relação a outras, incluem até mesmo aquelas atitudes que parecem bastante privadas, como as expressões da dor física de uma doença, ou da fé religiosa. Essas expressões de um gesto são geralmente muito complicadas e contraditórias, de modo que não podem ser expressas com uma única palavra e o ator deve compreender que dando à sua imagem a ênfase necessária, ele não perde nada, ao contrário, enfatiza o inteiro complexo. ${ }^{73}$ (BRECHT apud WILLET, 1977, p. 199, tradução nossa)

Brecht acreditava que tal complexo está ligado a um acontecimento a ser contado: “[...] a 'história', [Geschichte] é o coração da performance teatral. Pois é o que acontece entre pessoas que fornece todo o material que ela pode discutir, criticar, alterar". (BRECHT apud WILLET, 1977, p. 200, grifo e tradução nossos) Quando usou o termo Geschichte, ele não se referia ao gênero literário que prioriza a narração. Em uma peça didática de Brecht, uma "história" [Geschichte], pode ser uma cena curta, um evento, por exemplo, um acidente de tráfego que pode ser contado por várias testemunhas, sob vários ângulos. No teatro didático de Brecht, o que interessava

72 "[...] producing such images, is based on the 'alienation effect' (A-effect). A representation that alienates is one which allows us to recognize its subject, but at the same time makes it seem unfamiliar."

73 "The realm of attitudes adopted by the characters towards one another is what we call the realm of gest. Physical attitude, tone of voice and facial expression are all determined by a social gest: the characters are cursing, flattering, instructing one another, and so on. The attitudes which people adopt towards one another include even those attitudes which would appear to be quite private, such as the utterances of physical pain in an illness, or of religious faith. These expressions of a gest are usually highly complicated and contradictory, so that they cannot be rendered by any single word and the actor must take care that in giving his image the necessary emphasis he does not lose anything, but emphasizes the entire complex." 
era como os envolvidos no acidente deveriam ter agido para evitá-lo. Ele fazia um uso estratégico, teatral, da "história", para sustentar suas convicções políticas. Nesse processo, atores e espectadores desempenhavam o mesmo papel de aprendizes (lernendem), pessoas que estão compreendendo a história e aprendendo.

Para contar efetivamente uma "história", tratada nos pressupostos do efeito de "estranhamento", o gesto ganha espaço e qualidade particular, e começa a ser definido no corpo de cada ator, expandindo-se para os demais, gerando movimento, o que determinava ritmos e andamentos, interagindo com melodias, harmonias e contrastes para elaborar um tema visual:

O agrupamento das personagens no palco e os movimentos dos grupos devem ser tais, que a beleza necessária é alcançada, sobretudo, pela elegância com que o transporte de materiais que compõem o gesto é organizado e exposto à compreensão do público. ${ }^{74}$ (BRECHT apud WILLET, 1977, p. 200-201, tradução nossa)

Cada ator, ou grupo de atores, precisava ser compreendido como um sintoma de visualidade. Portanto, oferecendo o traço que fazia interagir todos os aspectos do espetáculo épico, proposto por Brecht, a história era contada visualmente:

A 'história' é definida, desenvolve-se é e mostrada pelo teatro como um todo, pelos atores, cenógrafos, aderecistas, figurinistas, compositores e coreógrafos. Eles unem suas várias artes para a operação conjunta sem, naturalmente, sacrificar sua independência no processo. ${ }^{75}$ (BRECHT apud WILLET, 1977, p. 200, tradução nossa)

A presença viva de personagens em cena para "contar" uma história exigia um comportamento específico, não somente do ator, mas de todo o complexo do espetáculo, que devia incorporar uma proposição estética particular:

[...] o cenógrafo recebe uma considerável liberdade, pois ao construir seus cenários, ele não tem mais que criar a ilusão de uma sala ou uma localidade. É suficiente dar indicações, ainda que elas devam fazer declarações de maior interesse histórico ou social, do que a coisa real faz. No Teatro Judeu, em Moscou,

\footnotetext{
74 "The grouping of the characters on the stage and the movements of the groups must be such that the necessary beauty is attained above all by the elegance with which the material conveying that gest is set out and laid bare to the understanding of the audience."

75 "The 'story' is set out, brought forward and shown by the theatre as a whole, by actors, stage designers, mask-makers, costumiers, composers and choreographers. They unite their various arts for the joint operation, without of course sacrificing their independence in the process."
} 
no [espetáculo] Rei Lear, uma estrutura que lembrava um tabernáculo medieval, causou o estranhamento; Neher pôs Galileu na frente de projeções de mapas, documentos e obras de arte renascentistas; para Haitang Erwacht, ${ }^{76}$ no Teatro Piscator, Heartfield ${ }^{77}$ utilizou um fundo de bandeiras reversíveis [uma espécie de porta-estandarte com face dupla] com inscrições, para marcar as mudanças na situação política da qual as pessoas no palco, às vezes, não tinham conhecimento. ${ }^{78}$ (BRECHT apud WILLET, 1977, p. 203, grifo e tradução nossos)

Brecht cita duas importantes figuras do teatro alemão daquele período: John Heartfield [pseudônimo de Helmut Herzfeld (1891-1968), artista plástico que nos anos de 1920 se notabilizou pelas suas montagens fotográficas, usadas nos seus cenários], e Caspar Neher (1987-1962), que trabalhou em estreita parceria com Brecht. Uma das mais recentes menções a essa parceria foi registrada no trabalho de Pamela Howard, publicado na sua primeira edição em 2001. Esclarecendo que o termo scenography deriva da expressão grega sceno-grafika, cuja tradução remeteria para o desenho (ou a grafia) do espaço da cena, sublinhando a sua profunda relação com os atores, já que eles representam seus elementos visuais primevos. Ela argumenta que os atores integram a scenography e a decisão de separar os cenários dos figurinos é, nesse sentido, uma contradição. A autora menciona a relação entre Caspar Neher e Bertholt Brecht, para apontar as raízes da scenography, no século XX, chamando a atenção para o trabalho coletivo e para a ideia de colaboração.

Howard (2009) afirma que Neher contribuiu tanto no que se refere ao contexto literário, quanto artístico, de modo geral. Nas montagens de $A$ ópera dos três vinténs e Ascenção e queda da cidade de Mahagonny ela vê em Neher o precursor daquilo

76 Ou Tai Yang Erwacht, como aparece no livro de John Willet, The theatre of Erwin Piscator: half a century of politics in the theatre, 1978, p. 105.

77 John Heartfield (1891-1968), cujo nome de batismo era Helmut Herzfeld, nasceu em Berlim. Especula-se que ele mudou seu nome em 1917, como protesto contra o exarcebado nacionalismo alemão da sua época, usando o pseudônimo John Heartfield até a sua morte; ilustrador, conhecedor das artes gráficas e da fotografia, considerado um precursor do design gráfico, passou pelo dadaísmo e trabalhou em arranjos cenográficos para espetáculos de Erwin Piscator (1893-1966).

78 " [...] the stage designer gets considerable freedom as soon as he no longer has to give the illusion of a room or a locality when he is building his sets. It is enough for him to give hints, though these must make statements of greater historical or social interest than does the real setting. At the Jewish Theatre in Moscow King Lear was alienated by a structure that recalled a medieval tabernacle; Neher† set Galileo in front of projections of maps, documents and Renaissance works of art; for Haitang erwacht at the Piscator-Theater Heartfield used a back ground of reversible flags bearing inscriptions, to mark changes in the political situation of which the persons on the stage were sometimes unaware." 
que hoje se entende como scenographer. Segundo a autora, ele desenvolvia grande intimidade com o texto e usava os atores, no espaço, para construir imagens com pessoas. Com um estilo graficamente simples e econômico, ele fazia continuamente uma variedade de pequenos desenhos, arranjos para a marcação, que Brecht usava como elementos da construção visual, em todo o espetáculo. Assim, Neher orientava espacialmente o autor/diretor e os atores, evidenciando o alto grau da sua contribuição para o teatro de Brecht. (HOWARD, 2009)

Na sua tese de doutoramento Caspar Neher e Bertholt Brecht: uma scenographic contribuition ${ }^{79}$ para o teatro épico (Caspar Neher and Bertholt Brecht: a scenographic contribuition to epic theater/1983), Ewald Hackler (1983) analisa o design e as montagens de três peças do início da carreira de Brecht - Na selva das cidades (Im dickicht, 1923), Homem é homem (Mann ist mann) (1926), e Ascenção e queda da cidade de Mahagonny (Mahagonny, 1927) - descrevendo a elaboração do texto, assim como a história das montagens, na primeira parte. Na segunda, ele aborda as soluções formais para os cenários, demonstrando sua tese através, inclusive, de desenhos de Neher, assim como de fotografias. No Abstract, Hackler (1983, grifo e tradução nossos) pondera:

Os projetos de Neher para as primeiras peças de Brecht mostram a evidência de uma experimentação teatral única. Seus 'arranjos cênicos' dissolvem as fronteiras entre as atribuições do diretor e do designer e, fazendo isso, ele demostra que a influência de Neher estendeu-se para além da esfera do meramente 'visual. ${ }^{80}$

As ilustrações referentes à montagem de Sr. Puntilla e seu criado Matt (Her Puntilla und sein knecht Matti, 1949), incluídas por Ewald Hackler no capítulo que conclui sua tese, representam importante documentação da parceria e da cumplicidade alcançada por Neher e Brecht. Diferentemente da prática da época, Neher acompanhava quase todos os ensaios para os espetáculos os quais fazia os cenários e não somente aqueles dirigidos pelo seu amigo Brecht. Para fazer os desenhos, Neher interagia com os agrupamentos dos atores elaborados por Brecht. Ou seja: num certo sentido, ele inverteu a ordem conhecida, na qual os cenários eram concebidos antecipadamente e entravam no processo como algo imutável. O processo aplicado por Neher foi largamente praticado no teatro alemão, à exceção da ópera e do balé. Um depoimento de Ewald Hackler, que trabalhou como assistente de Neher

\footnotetext{
79 Difícil traduzir: o trabalho de Neher é diferente das atribuições regulares de um "cenógrafo", no Brasil.

80 "Neher's designs for the early Brecht's plays give evidence of a unique theatrical experiment. His 'arrangment sketches' blur the conventional boundaries between the tasks of director and designer, and in doing so demonstrate the degree to which Neher's influence extended far beyond the sphere of the merely visual."
} 
na montagem de A morte de Gregori Rasputin, de Nikolas Nabokov, em 1959, dá conta que Neher, enfermo e frágil, não deixou de acompanhar os ensaios, desenhando por horas a fio.

Essa parceria apresentou um novo modo de construir a cena, apontando uma contribuição que se estendia para além daquilo que se caracteriza na abordagem aqui desenvolvida como mera visibilidade do design e abria um processo de coautoria, evidenciando uma visualidade particular. Egon Monk, um dos assistentes de Brecht, comenta:

Na mesa do diretor encontravam-se os desenhos [de Neher] sempre à mão. Em cima, o desenho da cena que está sendo ensaiada. Quase todos os arranjos [cênicos] das montagens no Berliner Ensemble referem-se diretamente aos desenhos de Neher. ${ }^{81}$ (MONK apud HACKLER, 1983, p. 254, tradução nossa)

O processo compartilhado por Caspar Neher e Bertolt Brecht revela um curioso fato visual: os cenários projetados por Neher pareciam "vazios e incompletos" sem os atores, sem a ação cênica. Essa é uma constatação fundamental para a compreensão da indissociabilidade entre o espaço que ele criava e a cena. Aliás, sem os seus arranjos de marcação, aquela cena não teria se desenvolvido. (HOWARD, 2009) Isso talvez permita ponderar que, para se efetivar de modo consistente na sua condição de obra artística, o espetáculo teatral dispensa uma intervenção "meramente" visível. Ou seja, quando a cenografia, o figurino, os adereços - a scenography - e a luz, quando cada um deles dá a efetiva contribuição artística para um espetáculo, o meramente visível desaparece. Desse modo, o caminho trilhado por Neher, ao introduzir sua contribuição para o teatro de Brecht, pode ser caracterizado como um processo muito diferente daquele que acentua a mera visibilidade.

Se considerarmos as exigências visuais do teatro de Brecht, talvez a luz pudesse ser aplicada de modo diverso daquele que aparece, especificamente, no Pequeno organon para o teatro, referindo -se a transições:

[...] os atores não devem 'mergulhar' [cair dentro] da canção, mas devem marcar claramente, separando-a do resto do texto; e isso é mais bem demonstrado por alguns métodos teatrais, como a mudança de luz ou inserção de um título. ${ }^{82}$ (BRECHT, 1977, p. 203, tradução nossa)

\footnotetext{
81 "On the director's desk [Neher's drawings] lay, always near at hand, on top the drawing of the scene in progress. Almost all arrangements of the Berliner Ensemble productions go straight back to Neher's sketches."

82 "the actors ought not to 'drop into' song, but should clearly mark it off from the rest of the text; and this is best reinforced by a few theatrical methods such as changing the lighting or inserting a title.
} 
Bertolt Brecht, no seu modo poético e com grande compreensão da questão, deu-se ao trabalho de escrever um poema para esclarecê-la. O poema representa um pequeno trecho da sua obra do qual muitos comentadores se mantiveram distantes, mesmo quando Brecht parecia representar uma das principais e definitivas saídas para as vanguardas do século XX.

É importante mencionar Esslin mais uma vez, quando ele comenta a opinião de Brecht sobre a ilusão de realidade, que deveria ser abolida para dar lugar à clareza, à lucidez e à racionalidade, em lugar da emoção desmedida que originava o descontrole, e dele se alimentava. Esslin (1980, p. 125) pondera: "Os inúmeros e variados dispositivos através dos quais a ilusão de realidade deve ser dissipada precisam ostentar a marca do trabalho honesto, a perfeição que vem do uso despretensioso e sem disfarce dos materiais [instrumentos]". ${ }^{33}$ Esslin (1980) cita, ainda, parte do poema A iluminação (Die beleuchtung), no qual Brecht adverte e faz apelos ao iluminador dos seus espetáculos:

Dê-nos luz sobre o palco, Iluminador! Como podemos nós,

Autores de peças e atores, apresentar na penumbra

Nossos retratos do mundo? A sombra do crepúsculo

Faz adormecer. Mas nós necessitamos do espectador

Desperto, alerta. Deixe que eles

Sonhem no claro!... ${ }^{84}$

(BRECHT apud ESSLIN, 1980, p. 125, tradução nossa)

Como infere Esslin, o palco deve ser completamente banhado de luz. Pode-se fazer uma analogia com um projeto de luz para um evento de moda ou para uma exposição de animais, como exemplo, nos quais as texturas, as formas e as cores originalmente planejadas, devem ser cuidadosamente preservadas. A continuação do poema até sugere procedimentos apropriados à visualidade do teatro épico:

O pouco da noite

Que precisarmos, agora e depois, nossas lâmpadas e luas

Podem indicar. E nós, com a nossa apresentação,

\footnotetext{
83 "The numerous and varied devices by which the illusion of reality was to be dispelled must bear the hallmark of honest craftsmanship, the perfection which comes from the unpretensions use of undisguised materials."

84 "Give us light on the stage, lighting engineer! How can we, | Playwrights and actors, present our images of the world | In semi-darkness? Nebulous twilight | Lulls to sleep. | But we need the spetators' | Wakefullness, even watchfulness. Let them dream | In blazing clarity! ..." Texto original: "Gib uns doch Lig auf die Bühne, Beleuchter! Wie | Können wir | Stückeschreiber und Schauspieller bei Halbdunkel | Unsre Abbilder der Welt vorführen? Die schummrige | Dämmerung | Schläfert ein. Wir aber brauchnen der Zuschauer | Wachheit, ja, Wachsamkeit. Laßsie | In der Helle träumen!"
} 
Também podemos mostrar os diferentes momentos do dia.

O Elisabetano deixou versos

Sobre uma charneca à noite, na qual nenhuma luz vai chegar.

Nem mesmo a charneca abraçará. Portanto, ilumine

O trabalho que fizemos

Para que o espectador possa enxergar

O camponês indignado

Sentar-se sobre o solo de Tavastland

Como se ela fosse sua própria terra. ${ }^{85}$

(BRECHT, 1967, p. 795, tradução nossa)

Partindo das demandas apresentadas pelo poema e, se nos referirmos à exigência de abolir os "disfarces" para mostrar a mecânica teatral desnudada é até possível traçar especulações para a teoria da luz no teatro científico [épico]. Esslin menciona ainda a desaprovação de Brecht para o uso de efeitos de luz com o objetivo de criar atmosfera e "clima", presumindo uma indicação presente no teatro de Shakespeare quando um disco que representava a lua, por vezes acompanhado de lamparinas na cena, indicava o estado de "noite".

Ficava, portanto, dispensada a redução da intensidade da luz no palco, a mudança de cor, textura ou ângulo. Mesmo por que, quando trabalhava no Globo, Shakespeare não poderia exigir tais interferências, sob a luz do sol. No teatro de Brecht, alojado numa edificação coberta e fechada, as decisões apontavam outra abordagem, ou seja: a deliberada intenção de mostrar, de expor e confirmar a presença do espectador no teatro, assistindo a um evento artificialmente planejado e executado. O palco deveria ser plenamente iluminado, com os instrumentos à mostra: "Ninguém espera que os instrumentos [spotlights/refletores] dispostos sobre um ringue de box estejam escondidos". 86 (BRECHT apud ESSLIN, 1980, p. 126) Do mesmo modo, Brecht não encontrava razão para que eles fossem camuflados no teatro. E, também, assistir a um dos combates incluía o desejo de "ver

85 "The little bit | Of night that's wanted now and then | Our lamps and moons can indicate. | And we with our acting too can keep | The times of day apart. | The Elizabethan wrote us | Verses on a heath at evening | Which no lights will ever reach | Nor even the heath itself embrace. | Therefore flood full on | What we have made with work | That the watcher may see | The indignant peasant | Sit down upon the soil of Tavastland | As though it were her own." Disponível em: 〈http://www.theatrecrafts.com//x_brecht.shtml〉. Acesso em: 11 abr. 2011.

"Das bißchen Nacht | Ab und zu gewünscht, kann mit Monden oder Lampen | Augedeutet werden, auch unser Spiel | Kann die Tageszeiten erkennbar machen | Dann, wenn es nötig ist. Über die abendliche Heide | Schrieb uns der Elisabethaner Verse | Die Klein Beleuchter erreicht, noch | Die Heide selber! Also beleuchter | Was wir erarbeitet, daß die Zuschauer | Sehen können, wie beleidigte Bäurin | Sich auf den tavastländischen Boden setzt |Als wär's der ihrige!"

86 "Nobody would expect the spotlights over a box ring to be hidden." 
claramente" os antagonistas e ser capaz de avaliar objetivamente a situação que determinaria os papéis de vencedor e derrotado. A estética da luz aplicada a uma contenda da "nobre arte" (o box) parecia indicada para que fossem mostrados os golpes desferidos pelo teatro de Brecht.

Um aspecto em particular dessa questão pode ser sublinhado: como Brecht avaliaria as possibilidades de lâmpadas, instrumentos e filtros, hoje disponíveis, considerando sua predileção pelo teatro de Shakespeare, realizado sob a luz do sol? Ainda que aspectos de natureza geográfico-climática interfiram diretamente na ação do sol, de acordo com cada região do planeta, quando se pensa numa temperatura de cor média para a luz do sol, algo em torno $5.400 \mathrm{~K}$, o resultado é uma luz azul muito brilhante e reduzida saturação, que nos leva a ver "branco". O senso comum leva o olho humano a ver "branco" onde há um azul tão sutil que exige atenção particular para ser efetivamente percebido.

Na verdade, o mencionado azul comporta-se como um "branco de referência" (o mais próximo da luz branca que se poderia alcançar), em comparação com as limitações das lâmpadas incandescentes disponíveis no século passado, que não produziam mais que uma luz amarelada, em muito distante da temperatura de cor da luz do sol que alcança a terra, depois que já se elevou na atmosfera e antes de começar a se por.

O que se produzia no teatro, então, era uma luz com temperatura de cor muito aquém do branco de referência que se vê na iluminação natural durante grande parte do dia. Por um lado, banindo as cores que criavam os "climas" realistas e emocionais do teatro da sua época e iluminando completamente o palco ele se afastava da visualidade apresentada pelo teatro realista; por outro, a cor produzida pelos instrumentos (refletores), vinculados às lâmpadas e sistemas de controle disponíveis àquela época, banhando o seu palco com uma luz amarelada, influenciada pelos vermelhos e teatralmente romântica, o aproximava do teatro que ele combatia. Talvez valesse a pena introduzir no seu teatro uma luz fria, desde a família dos cianos e subindo na temperatura de cor, situando-se na categoria ou qualidade do branco (de referência) para expor a cena de modo científico, perscrutador.

É preciso levar em conta que com os instrumentos que Brecht conheceu seria difícil imaginar essa luz "branca", no palco. Mesmo a luz cirúrgica da época redundaria amarelada quando se considera a alta temperatura de cor que algumas lâmpadas oferecem hoje, aliada aos filtros (gelatinas) disponíveis. O que Brecht queria era uma luz intensa, sem a influência de dimmer e/ou dos filtros coloridos de alta saturação, como até hoje se usa corriqueiramente, e até sem qualquer critério artístico. 
Qual seria a reação de Brecht, sentado hoje numa plateia, diante de uma luz efetivamente expositiva, criada pela aplicação de filtros indicados para alcançar uma temperatura de cor que afaste os amarelos alaranjados da luz incandescente e sem a redução da intensidade que abranda a imagem? Brecht poderia sentir-se contemplado se, hoje em dia, ele trabalhasse com um theatre lighting designer que aplicasse em suas montagens do teatro científico uma investigação competente de IRC (índice de reprodução de cor) que resultasse na aplicação de lâmpadas capazes de desconstruir a visualidade romântica das antigas lâmpadas incandescentes. Portanto, intervenções que pudessem modificar as características visuais de cada elemento do espetáculo somente seriam feitas depois de discussões que as referendassem.

Vale ainda mencionar um importante aspecto da convenção visual proposta por Brecht, relacionado ao uso da cortina:

[...] e faça | minha cortina, com metade da altura, não ponha um lacre no palco! | Recostado na cadeira, deixe que o espectador | Esteja ciente dos vívidos preparativos, feitos para ele | Engenhosamente; ele vê uma lua recortada de uma folha de alumínio | Flutuar para baixo, ou um telhado | transportado para dentro do palco. ${ }^{87}$ (BRECHT apud ESSLIN, 1980, p. 126, tradução nossa)

A cortina de meia altura, na verdade, tinha dimensões menores do que a boca de cena, tanto no sentido horizontal quanto vertical, para permitir que o espectador enxergasse parcialmente o que acontecia no palco, mesmo quando ela estava fechada. Era possível perceber o trânsito dos técnicos, pois parte do piso do palco permanecia visível; também se podia enxergar elementos do cenário por cima da cortina, já que ela não fechava completamente a dimensão vertical da boca de cena.

Brecht deixou escapar aí outra nuança da sua compreensão da natureza teatral, da natureza artística do seu objeto: "não mostre muito, | mas dê a ele alguma coisa | E deixe-o perceber que vocês não são magos, | Amigos, mas trabalhadores [...]”.88 (BRECHT apud ESSLIN, 1980, p. 126, tradução nossa) Ele indicou uma qualidade provocativa numa mistura que anunciava o que está por vir na cena, despertando atenção do espectador, mostrando a "máquina cênica" em funcionamento. A visualidade como índice norteador.

87 "[...] and make | my curtain half high, don't seal off the stage! | Leaning back in his chair, let the spectator | Be aware of busy preparations, made for him | Cunningly; he see a tinfoil moon | Float down, or a tiled roof | Being carried in."

88 "do not show him too much, | But show him something! And let him notice | that you are not wizards, | Friends, but workers [...]." 


\section{A DANÇA DA SAIA OU O CORPO COMO MOVIMENTO EXPRESSIVO}

Se o gesto e o movimento no teatro de Brecht deviam buscar um específico grau de racionalidade vinculada a propósitos científicos de acordo com os quais o estranhamento se daria também na abordagem visual do corpo do ator, observa-se, no trabalho de Loie Fuller [Marie Louise Fuller (1862-1928)], um interesse diferenciado pelo tom expressivo do corpo em movimento. Ela fez interagir sua intuição de artista com instrumentos produzidos pelo progresso científico do seu tempo para criar abstrações visuais radicais através do movimento, subvertendo o contexto teatral que acentuava a representação realista de personagens.

Diante de argumentação que vincule exclusivamente sua proposição cênica ao trabalho de uma dançarina e/ou coreógrafa pode-se questionar a imposição de fronteiras ou limites entre teatro e dança. Ainda que suas inovações possam ter sugerido interferências muito relevantes nas relações entre a luz e a cena, inscrevendo mesmo seu interesse na face científica da questão, é necessário refletir sobre a repercussão da sua abordagem espetacular do corpo em movimento. Desse modo, pode-se observar as contribuições de Loie Fuller para a pesquisa estética vislumbrando-se na sua investigação mais do que um exclusivo fascínio por inovações técnicas. Ficava indicada uma conjuntura que compreendia a atriz - e/ ou a dançarina - como figura, objeto ou, corpo em movimento, o que apontava para o reconhecimento da natureza cênica do corpo em si.

É então possível reconhecer também outra relevância das iniciativas de Fuller: nas suas danças o palco pode ganhar o status de lugar por excelência da ação, destituindo quaisquer intenções da representação ou figuração de qualquer outro ambiente, como resumiu Arnold Aronson (1991, p. 4) (historiador, professor da Columbia University), tratando do design moderno no teatro: "Antes de qualquer coisa, o palco não era ilusionista, ele era identificado como um palco ou um espaço para o trabalho do ator, não outro lugar qualquer, como uma sala, uma floresta, etc." ${ }^{89}$ Os movimentos estabeleciam autonomia artística para a dançarina na sua condição de corpo-espaço totalizado e totalizador da cena. A performance podia constituir-se cruamente de um corpo em movimento, no instante mesmo da sua ocorrência, elegendo o corpo do ator como espaço e objeto primevo daquela práxis cênica, um corpo que se bastava como objeto expressivo e cuja manifestação cênica exigia outros dois parceiros: a luz e o público.

89 "First of all, the stage was not illusionistic - it was identified as a stage or a space for acting, not as some other place, such as a room, a forest, etc." 
É importante observar, contudo: se por um lado, o performer ganhava o status de corpo autônomo, impondo sua presença como resultado de uma "trinomia" que fisicalizava em cena uma simultaneidade mágica efetivada em corpo/meio/ imagem cujo movimento o apresentava como uma multiplicidade formal, por outro, a individualidade do ator era diluída para favorecer a elaboração de formas abstratas em movimento. Ou, como tentou resumir Roubine (1982b, p. 22): “[...] se a luz tende a tornar-se protagonista do espetáculo, por sua vez a dançarina tende a dissolver-se, a não ser mais do que uma soma de formas e volumes desprovidos de materialidade".

Ainda que se possa questionar a compreensão de "materialidade" delineada por Roubine (1982b) - uma vez que as formas e os volumes configuram objetivamente a natureza material da imagem cênica - é possível dizer que o trabalho de Loie Fuller determinava, sim, a dissolução da personagem, dissolução que seria mais tarde reclamada por iniciativas que desejariam afastar o drama do contexto teatral. De modo geral, um espetáculo projeta imagens relacionadas com uma interpretação particular da vida, de acordo com a abordagem estético-poética do artista que o concebe; O contato com o trabalho de Loie Fuller pode, por conseguinte, indicar espaços para uma investigação particular da cena como imagem diferenciada daquela imagem bidimensional produzida por aparelhos, presente em abordagens que estudam a iconologia, a pintura, a fotografia e até o medium eletrônico-digital contemporâneo, desde Erwin Panofski (1892-1968, crítico e historiador da arte alemã, um dos principais representantes dos estudos acadêmicos em iconografia) até Vilém Flusser (1920-1991, filósofo e autor, nascido em Praga e naturalizado brasileiro), mencionados aqui como exemplos.

La Loie oferecia o próprio corpo como meio para a fisicalização de múltiplas imagens em movimento, elaboradas de modo fluido na cena. A presente abordagem procura ocupar um espaço de discussão diferente daquele que estuda a imagem como um produto de aparelhos, de meios externos, localizados - vale a tautologia, fora do corpo, ou como uma entidade abstrata, teórica. Ao invés disso, a abordagem em curso aproxima-se também da compreensão das imagens como "representações internas" geradas em uma unidade corpo-mente, seja o ator ou o fruidor, organicamente relacionadas à imagem fisicalizada na cena, aquilo que é percebido visualmente em um acontecimento teatral.

Loie Fuller iniciou sua carreira no teatro desde a infância, declamando poemas já aos quatro anos. Desde o final da década de 1870, ela apareceu em vários espetáculos, com pequenos papéis, até mesmo produzindo, escrevendo e viajando com um circo. Em 1884, deixou o teatro para, segundo declarou, estudar música. No ano seguinte, Fuller participou como cantora na montagem de Fausto, no Teatro de 
Ópera Hooley e também no Festival de Música, ambos em Chicago. Voltando a trabalhar como atriz em 1886, fez alguns papéis masculinos - o que era comum, na época. Trabalhando no vaudeville, em 1887, Fuller interpretou Marguerite Gauthier, quase acidentalmente, onde usou sua experiência em tournées como ela relata:

Provei isso repetidamente aceitando papéis inesperados dos quais eu não sabia uma palavra um dia antes da estreia. Isso aconteceu, por exemplo, quando interpretei Marguerite Gauthier, em A dama das camélias, com apenas quatro horas para aprender o texto. ${ }^{90}$ (FULLER, 1913, p. 23, tradução nossa)

Em 1889, casou-se com William Hays e mesmo que nunca tenham efetivamente vivido como um casal ele parecia muito dedicado, a ponto de acompanhá-la numa viagem a Londres, onde assumiu a posição de esposo, além de arcar com todas as despesas. Sem grande sucesso, Fuller retornou a Nova York em 1890, engajando-se em dois espetáculos: a comédia musical Viagem à Chinatown (Trip to Chinatown), de Charles Hoyt, e Dr. Quack (Quack, M.D.). Segundo seu próprio relato, durante os ensaios de Dr. Quack, o autor decidiu incluir uma nova cena na qual o Dr. Quack hipnotizava uma viúva; o hipnotismo estava em voga na cidade de Nova York. Ela comenta a solução para a cena, no espetáculo propriamente dito:

Para dar à cena seu efeito completo, ele precisava uma música muito doce e iluminação indeterminada. Nós pedimos ao eletricista do teatro para colocar lâmpadas verdes na ribalta e ao regente para executar uma air ${ }^{91}$ suave. $^{92}$ (FULLER, 1913, p. 25, tradução nossa)

É importante registrar a escolha do verde, como uma família cromática distante do espectro da luz natural, estabelecendo uma qualidade visualmente "estranha". Para encaminhar a solução do problema, faltava, entre outros detalhes, o figurino. Sem dinheiro para comprar um novo vestido, Fuller decidiu buscar uma solução entre as suas próprias roupas. Por mero acaso, encontrou no fundo de um dos

\footnotetext{
90 "I have proved it repeatedly by unexpectedly taking parts of which I did not know a word the day before the first performance. It was thus, for instance, when I played the part of Marguerite Gauthier in La Dame aux Camélias with only four hours to learn the lines."

91 Uma melodia ou canção, ligada aos registros tenor ou soprano. Pode remeter também a um solo sem acompanhamento. O termo "air" [ária] pode se referir também a uma dança de origem renascentista, que entra como forma musical do Barroco, nas sequências de danças, ou música instrumental que reúne um ciclo de danças. Aparecem, como exemplo, na obra de Johan Sebastian Bach (1685-1750), suítes francesas, suítes inglesas. A melodia da Ária em G (sol ou quarta corda) é um exemplo notabilizado.

92 "To give the scene its full effect he needed very sweet music and indeterminate illumination. We asked the electrician of the theatre to put green lamps along the footlights and the orchestra leader to play a subdued air."
} 
seus baús uma pequena caixa, de não mais que 20 centímetros de largura, dentro da qual havia uma fina, comprida e rodada saia branca, de seda, presente de um oficial do exército britânico que se encontrava na Índia. Ela decidiu fazer a cena, usando essa que chamou de saia hindu, transformando-a numa espécie de túnica ou manto, uma vez que era muito comprida. (Cf. Figura 105)

Apesar disso, com quase um metro além do tamanho de uma saia que lhe coubesse de modo justo, o manto criava dificuldades para o deslocamento no palco. Para flutuar misteriosamente no palco, hipnotizada sob a melancólica atmosfera da música e o verde pálido da ribalta, ela abriu os braços sugerindo a presença de um "espírito alado", seguindo o médico que se deslocava cada vez mais rapidamente no palco. Fuller relata as respostas da plateia: "É uma borboleta!”; “É uma orquídea!” Seguidas de forte aplauso. Sua descrição do final da cena registra a reação do público:

Por fim, petrificada, em estado de êxtase, deixei-me cair a seus pés, completamente envolta em uma nuvem de tecido leve. O público pedia bis, e pedia novamente, tão alto e tantas vezes que tivemos que voltar vinte vezes, ou mais..$^{93}$ (FULLER, 1913, p. 31-32, grifo e tradução nossos)

Entretanto, depois de um mês e meio de temporada, a peça estreou nos subúrbios, recebendo ataques dos críticos, e não logrou espaço nos teatros de Nova York, ainda que a "atuação" de Fuller na cena do hipnotismo - como ela denominou - tenha gerado o entusiasmo de um dos críticos da cidade, e também repercutido de modo positivo na imprensa. Finalizada a temporada, e sem recursos financeiros para assumir um espetáculo exclusivamente com o seu número, ela decidiu fazer alguns reparos necessários no manto depois do repetido uso nos espetáculos. Ao concluir, ela vestiu a indumentária sobre a camisola de dormir, para relembrar os movimentos. O acaso mais uma vez mostrou um surpreendente resultado; filtrado pela cortina, o sol lançou sobre o tecido uma luz âmbar, criando translucidez e reflexos dourados nas dobras cintilantes da seda, revelando vagamente seu próprio corpo. Sob o efeito dessa visão, ela experimentou movimentos e revelou mais tarde que ficou convencida de haver elaborado ou descoberto algo novo (Figura 112).

Vale dizer que tal natureza de movimento ou coreografia já tinha alguma popularidade em Londres e que Kate Vaughan, nome artístico de Catherine

93 "At last, transfixed in a state of ecstasy, I let myself drop at his feet, completely enveloped in a cloud of the light material. The audience encored the scene, and then encored it again - so loudly and so often that we had to come back twenty times, or more." 
Candelin (1853-1903), já havia se apresentado em 1873 como dançarina-da-saia, no Balé das fúrias [Ballet of the furies], segundo afirma Clare de Morinni (2010). ${ }^{94}$ Ela interpretava o Espírito das Trevas, envolta em uma longa saia preta, repleta de ornamentos dourados e palidamente iluminada de frente, como se estivesse ao luar. Logo depois desse espetáculo, no Anfiteatro de Holborn (1873), Vaughan apresentou outras versões dessa dança, usando leves saias de gaze, no Gaiety Theatre, em Londres. Coreografias ou performances com a mesma tendência tornaram-se conhecidas e imitadas.

O que Loie Fuller (1913) buscava, no entanto, diferenciava-se através do seu vigoroso interesse pelo movimento e pela sua confiança na contribuição da luz. Depois de pesquisar relações entre a extensão de tecido, os movimentos, as consequentes formas que integravam todo o seu corpo e, contando com as observações de duas amigas, ela resumiu: "Finalmente cheguei a um ponto onde cada movimento do corpo se expressava nas dobras da seda, com uma ação de cores, que podiam ser matemática e sistematicamente calculadas". ${ }^{95}$ (FULLER, 1913, p. 31-32, tradução nossa) Sua atenção para a possibilidade de calcular e planejar indicava o caráter investigativo do trabalho de uma performer que se empenhava em desenvolver um método nas suas pesquisas para a cena.

Na mencionada primeira fase, Fuller (1913) chegou a 12 "movimentos característicos" - como ela denominou - identificados por números e pela cor a ser aplicada em cada um deles. A dança n. ${ }^{\circ}$ 1, com luz azul; a n. ${ }^{\circ} 2$, luz vermelha; a n. ${ }^{\circ}$, amarela. Tocada pela cor, pelo poder expressivo da luz nas relações entre cor e forma, ela imergia na pesquisa: "Para a iluminação das minhas danças, eu pretendia usar um refletor com vidro colorido na frente da lente. Eu queria a última dança em total escuridão, com um único raio de luz amarela cruzando o palco". ${ }^{96}$ (FULLER, 1913, p. 34-35, tradução nossa) Nessa declaração ela fez mais um registro da contundência da luz na proposição da cena, desde os seus primeiros passos, quando um espetáculo que será montado ainda se constitui de imagens mentais elaboradas por um artista que concebe e/ou planeja a cena.

O contato com agentes e administradores (produtores) de teatros, contudo, não deu o resultado que Fuller desejava. Todos se negavam a aceitá-la como dança-

\footnotetext{
94 O artigo de Morinni aparece no título organizado por Paul Magriel (1906-199o, colecionador de arte, curador dos arquivos de dança do Museu de arte Moderna - NYC) depois de ser originalmente publicado no periódico Dance Index, em março de 1942, e é considerado um dos mais importantes relatos biográficos sobre Loie Fuller. 95 "Finally I reached a point where each movement of the body was expressed in the folds of silk, in a play of colours in the draperies that could be mathematically and systematically calculated."

96 "For illumination of my dances I intended to have a lantern with coloured glass in front of the lens. I wanted to dance the last one in total darkness with a single ray of yellow light crossing the stage."
} 
rina e somente com a intervenção de um amigo comum ela conseguiu acesso a um produtor que aceitou a ideia de assistir uma das suas danças. Não havia um camarim disponível, muito menos um piano para acompanhá-la e, como iluminação, somente um bico de gás. Pondo a "saia" sobre o próprio vestido com o qual havia chegado ao teatro, ela começou sua apresentação, lentamente, na penumbra. O produtor aproximou-se cada vez mais, e subiu ao palco; segundo ela, com olhos brilhando. Fuller (1913, p. 38, tradução nossa) continuou dançando, distanciando-se para a escuridão, e retornando para o alcance do facho da luz de gás. Sua descrição do último trecho é muito peculiar: "Finalmente, eu levantei uma parte do manto sobre meus ombros, fiz uma espécie de nuvem que me envolveu completamente e então caí, uma massa flutuante de seda macia, aos pés do produtor". ${ }^{97} \mathrm{Com}$ brilho nos olhos, o homem reagiu dizendo que chamaria a apresentação de $A$ dança da serpentina (The serpentine dance).

Antevendo o sucesso - e os lucros - ele ofereceu um contrato de cinquenta dólares por semana apressando-se em escolher uma música para acompanhá-la, Au loin du bal, ${ }^{98}$ que se lhe tornaria familiar, a partir de então. Ela aceitou o pequeno salário pedindo que, em contrapartida, seu nome fosse divulgado, numa tentativa de retomar o contato com o público e afirmar sua nova empreitada. Juntou-se, então, a uma companhia desse mesmo produtor, que partiria em tournée. Um mês e meio depois, já no Brooklyn, sua dança alcançara grande sucesso e, mesmo com o sucesso repetido em Nova York, com a reação muito favorável da crítica, seu nome ainda não aparecia nos anúncios e letreiros que eram largamente distribuídos. Ao reclamar, descobriu: temendo que outro agente lhe tirasse a cliente, o homem havia deliberadamente evitado que a autoria das danças fosse conhecida.

Sem conseguir convencê-lo a incluir seu nome na divulgação que se espalhava pela cidade, ela procurou outro teatro. No dia seguinte, comparecendo para já assinar um contrato, foi informada que sua dança continuava sendo anunciada pelo antigo produtor, com outra dançarina em seu lugar. Por essa razão foi obrigada a aceitar condições contratuais pouco favoráveis, estreando e mantendo grande sucesso durante toda a temporada no Madison Square Theatre, enquanto o teatro que a havia substituído logo retirou rapidamente o número de cartaz. Não se tratava de substituir uma dançarina, mas de levar ao público um espetáculo que promovia uma interação diferenciada entre a luz e a cena, através de um conjunto expressivo de movimentos, formas e cores.

97 "Finally I lifted a part of my robe over my shoulders, made a kind of cloud which enveloped me completely and then fell, a wavering mass of fluffy silk, at the manager's feet."

98 Ou, Loin du bal, de Ernest Gillet (1856-1940), compositor francês, ativo no pós-romantismo. 
O olhar atento às manifestações da luz ficou registrado nas suas memórias, aparecendo de modo peculiar quando ela relatou sua primeira visita à Catedral de Notre-Dame, em Paris, e comentou o incidente que resultou em sua retirada do interior da igreja: fascinada com a luz do sol que entrava pelos enormes vitrais góticos ela usou um lenço branco para experimentar os efeitos da luz colorida, assim como fazia no teatro, com sua saia especial. Um dos responsáveis pelo respeito e disciplina, no interior do templo, levou-a pelo braço até colocá-la do lado de fora. A observação da luz gerou também sua crítica à iluminação de museus, para os quais ela indicava o planejamento da luz, acentuando-a como um recurso pouco estudado. Criticando os processos convencionais de formação em dança, que definiu como movimentos de braços e pernas, Fuller (1913, p. 68, tradução nossa) indica a necessidade de um desafio dos limites expressivos do corpo humano e simplifica a sua busca: "Luz, cor, movimento e música". 99

Desde sua primeira passagem pela França, já desligada do marido e tendo passado por Berlim e Hamburgo ela registrou a frustração de não haver sido aprovada para o Opéra, em Paris. De todo modo, desconsiderando a fama de lugar pouco indicado para uma atriz respeitável, ela apresentou-se ao Folies Bergère, encontrando ali uma dançarina que fazia performances parecidas com suas danças, à qual os comentadores se referem como imitadora. Apesar disso, Loie Fuller alcançou grande sucesso nessa casa de espetáculos, mudando a reputação da mesma, até levando aos seus espetáculos senhoras e crianças em horários especialmente planejados. Continuando sua pesquisa ela buscava novos efeitos, tornando particularmente conhecida a coreografia Dança do fogo (Fire dance), como se pode ler no depoimento de Morinni (1913, p. 210, grifo do autor):

[...] 'Fire dance', foi particularmente popular, por causa dos efeitos de fogo e fumaça, que ela produzia dançando sobre um painel de vidro, iluminado por baixo. Essa inovação, uso pioneiro de luz indireta, era um efeito 'maior que o Bayreuth', e foi inspiração direta para a litogravura de Toulouse Lautrec [Figura 113]. ${ }^{100}$

Sua presença no ambiente artístico de Paris rendeu-lhe notoriedade fazendo com que outros artistas, além de Toulouse-Lautrec, se voltassem para sua figura. Jules Chéret (1836-1932) fez o cartaz das suas apresentações no Folies Bergère; ela tornou-se tema de uma pintura de Mantelet (Albert Mantelet, 1858-?); Rodin

99 "Light, colour, motion and music."

100 “'Fire dance', was particularly popular, because of the effects de flame and smoke produced by dancing in a pane of glass lighted from beneath. This innovation, a pioneer realization of indirect light, was an effect 'greater than Bayreuth', and was the direct inspiration for the Toulouse Lautrec lithograph." 
(François-Auguste-René Rodin, 1840-1917) elogiaria os efeitos de luz que ela criou; Alexandre Dumas insistiu que ela escrevesse suas memórias; e Mallarmé (1897, p. 181) a transformou em La Loie: "[...] essa transição de sonoridades do tecido (ou, melhor, uma gaze que remete à música!) é, apenas, a magia que La Loie Fuller realiza por instinto, com exagero, elevações, saia ou asa, instituindo um lugar". ${ }^{101}$

A caracterização do "lugar" nas performances de Loie Fuller pode ser relevante quando se compreende sua pesquisa como uma nova maneira de tratar o locus cênico, tornando-o abstrato, "lugar-nenhum" e palco em si, no qual se fisicalizava um novo corpo "desfigurado" em seda, ainda que, sob a intensidade dos movimentos da performer seu corpo até poderia responder aos desejos do público de ver representações figurativas no palco. O espectador integrava a totalização da elaboração artística, inclusive, com exclamações: "Uma orquídea! Uma borboleta!". A expectativa de "ver" algo familiar na cena aparece até na dúvida poética de Mallarmé: trata-se de uma saia ou são asas? Loie Fuller, portanto, indica a força da qual o ator deve impregnar seu trabalho se ele busca provocar o público, fazendo-o assumir o papel de membro do coletivo que fisicaliza a cena. Nem sempre um título rebuscado, acompanhado de longo subtítulo, alcançará tal objetivo.

Depois dessa primeira fase em Paris, Fuller começou a apresentar espetáculos nos quais era acompanhada por um grupo de jovens dançarinas, enquanto expandia seus conhecimentos da luz teatral. Permanecendo algum tempo com apenas um instrumento (um refletor) de cada lado da cena, ambos com a mesma cor, ela começou a fazer mudanças, ampliando o número de instrumentos, mas mantendo uma cor de cada vez. Devido a um acidente relatado por Clare de Morinni, que parece cercado por um tom de anedota, Fuller mudou radicalmente o resultado visual das suas danças. Um eletricista bêbado (vários técnicos trabalhavam no espetáculo, atendendo a deixas que ela indicava por gestos, como sinais para cada mudança) usou várias cores simultaneamente, deixando-a furiosa. Após perceber a reação positiva da plateia e demonstrando perspicácia, ela incorporou a mixagem de cores, cujo resultado renderia um comentário no jornal sketch, de Londres:

A orgia de cor era tão maravilhosa que deixava muda qualquer objeção. A luz vinha de todos os lados. La Loie dançou em cima do vidro, do qual o vívido esplendor da luz refletia, enquanto das coxias, do palco e da orquestra, maravilhosos fluxos luminosos pareciam fluir em sua direção. Com o ritmo da música, as cores mudaram, e onde o branco antes governara, havia uma

101 "[...] cette transition de sonorités aux tissus (y a-t-il, mieux, à une gaze ressemblant que la Musique!) est, uniquement, le sortilège qu'opère la Loie Fuller, par instinct, avec l'exagération, les retraits, de jupe ou d'aile, instituant un lieu." 
visão caleidoscópica. Movimentos de violeta, laranja, púrpura e cor de malva [algo entre o magenta e o violeta] se sucediam rapidamente até que um rico e profundo vermelho dominou a dançarina, e ela se tornou, por um breve momento, uma rosa viva, com o coração palpitante e folhas que voavam. Em segui$\mathrm{da}$, os tons do arco-íris vieram de todos os lados, e caindo sobre as cortinas em movimento constante. Cada dobra de tecido tinha sua tonalidade e esquema de cor, intensificados pela escuridão envolvente, até que o olho mal podia suportar. Então, quando a tensão estava se tornando quase insuportável, as cores desapareceram, viu-se um flash branco de brilho espantoso e La Loie desapareceu sob a diáfana indumentária. ${ }^{102}$ (SKETCH apud MORINNI, 2010, p. 211, tradução nossa)

Loie Fuller empenhou-se cada vez mais nessa pesquisa, na qual aplicava a maior parte do dinheiro que recebia, mantendo uma equipe experimental de seis eletricistas e fazendo diversos experimentos que incluíam, segundo Morinni, "sais fluorescentes", derivados do mineral pechblenda (do qual se extrai o urânio em forma de um sal amarelo). Antoine Henri Becquerel (1852-1908) descobriu que essa pedra emitia uma forte luz, capaz de atravessar objetos opacos. Da pesquisa com a pechblenda, o casal Marie Curie (1867-1934) e Pierre Curie (1859-1906) desenvolveram pesquisas com o radium. Loie Fuller teria se aproximado do casal, intrigada com a notícia de que o radium podia prover uma luz mágica e pálida. Ela apresentou-se na casa da família onde tomou conhecimento das dificuldades práticas da aplicação do radium na cena. Funcionando ou não, ficou registrada a postura de uma artista atenta às diversas possibilidades da abrangência de aplicação dos diversos materiais no seu trabalho.

O depoimento do historiador e romancista Jules Claretie (1840-1913), publicado no jornal Temps, em 5 de novembro de 1907, pode corroborar tais elaborações:

Na noite passada [...] eu tive, por assim dizer, uma visão do teatro do futuro, [...] algo da natureza de um teatro feminista. [...] As mulheres estão, cada vez mais, ocupando o lugar dos ho-

\footnotetext{
102 "The orgie of color was so wonderful as to leave objection mute. Light came from every side. La Loie danced upon glass, from which the vivid splendor of the headlights was reflected, while from the the wings, stage and orchestra, wonderful luminous streams seemed to flow toward her. With the rhythm of the music the colors changed, and where white ruled before, there was a kaleidoscopic vision. Violet, orange, purple and mauve movements succeeded in rapid sucession until a rich deep red dominated the dancer, and she became, for one brief moment, a living rose, with palpitating heart and flying leaves. Then the hues of the rainbow came from all sides and ranged themselves upon the ever moving draperies. Every fold had its tint and scheme of color intensified by the sorrounding darkness until the eye could scarcely bear to look. Just as the strain was becoming almost intolerable, the colors desappeared, there was a white flash of appaling brilhancy and la Loie faded under diaphanous drapery."
} 
mens. [...] Loie Fuller tem feito muitos estudos em um laboratório especial, de todos os efeitos da luz que transforma o palco, [...]. É certo que novas possibilidades estão se desenvolvendo na arte teatral e que a Srta. Loie Fuller tem dado uma importante contribuição. ${ }^{103}$ (CLARETIE apud FULLER, 1913, p. 282-285, tradução nossa)

Quem ainda hoje, depois dessa descrição, mergulha, impensadamente em efeitos de cores, fumaça e movimentos pode, portanto, reconsiderar: realizar tal categoria de efeito, como novidade ou saída técnica para a luz na cena, é repetir algo antigo; mesmo se for empregada a tecnologia mais atual. Assim foi no tempo do primeiro color changer (variador de cor), do uso redutor do elipsoidal como "maquininha" de efeito, do intellabeam e depois tecnobeam (exemplos da tecnologia de instrumentos de iluminação cênica com gabinete fixo e moving mirror - ou espelho com movimento automatizado), do moving head (instrumento automatizado, com gabinete e espelho móveis) com lâmpadas incandescentes, do PAR (Parabolic aluminized reflector) que aplica a tecnologia do led, ou qualquer inovação tecnológica que se venha a aplicar. ${ }^{104} \mathrm{O}$ uso da fumaça combinada com filtros coloridos, com padrões gráficos e movimento pode sugerir muita "criatividade" e agradar o senso comum. Mas é antigo. Sua eficiência foi confirmada antes da consolidação da eletricidade, por Marie Louise Fuller, há mais de um século.

Levando em consideração apenas o depoimento de Claretie talvez ainda seja possível especular acerca de outras contribuições deixadas por ela, como o controle do tempo-ritmo de um efeito ou movimento. Pode-se também argumentar que ela teria definido intuitivamente tal procedimento; de todo modo, cabe registrar seu exaustivo trabalho de pesquisa, que, provavelmente, incluía investigações de processos químicos para produzir efeitos no tecido da sua indumentária. Suas danças tornavam o palco, como já foi dito, um lugar cênico híbrido e/ ou indefinido, e a artista em um corpo-espaço abstrato, expresso em cor, forma, textura e movimento. Para tanto, a luz que incidia sobre a cena devia ser operada com extrema precisão, exigindo um processo de comunicação entre aquela que elaborava e aqueles que controlavam os instrumentos, como ela definiu:

103 "The other evening [...] I had, as it were, a vision of a theatre of the future, [...] something of the nature of a feministic theatre. [...] Women are more and more taking men's places. [...] Loie Fuller has made studies in a special laboratory of all the effects of light that transform the stage, [...] It is certain that necapacities are developing in theatrical art, and that Miss Loie Fuller will have been responsible for an important contribution."

104 Acessórios considerados a última novidade, em seu tempo. 0 mais importante apelo de cada um deles é definir a luz projetada na cena e/ou fazer mudanças automaticamente, para criar efeitos ilusionistas. 
Um eletricista qualificado tem que chegar à frente para cortar o piso corretamente e arranjar os fios. Depois disso, eu posso trabalhar. Às vezes eu uso dez lâmpadas, por vezes, dezesseis, vinte, já usei trinta e quatro, e isso requer um eletricista qualificado, para operar cada uma delas. ${ }^{105}$ (FULLER apud MORINNI, 2010 p. 211, tradução nossa)

Aqui se pode registrar como o treinamento dos técnicos já era indispensável, assim como sua relevância para a cena. Em outro trecho do seu livro de memórias, ela menciona a estreia no Folies Bergère, tocando em pontos importantes dessa relação:

[...] o ensaio geral só terminou às quatro horas da manhã, e eu ainda não tinha conseguido completar meu programa, que compreendia cinco danças: 1, a serpentina; 2, a violeta; 3, a borboleta; 4 , uma dança que o público mais tarde chamou de 'dança branca'. Para concluir, eu pretendia dançar com iluminação de baixo, a luz vindo através de um quadrado de vidro sobre o qual me encontrava, o que seria o clímax das minhas danças. Após o [ensaio do] quarto número, meus eletricistas, que estavam esgotados, me deixaram lá, sem a menor cerimônia. ${ }^{106}$ (FULLER, 1913, p. 57, tradução nossa)

Como se pode constatar, ela também pode haver cometido erros, pois a efetiva contribuição da luz para um espetáculo exige disciplina para ser concebida, planejada e executada. Nem sempre é possível fazer a "mágica", num passe de mágica; exaurir uma equipe pode produzir resultados negativos no espetáculo. Afinal, como já foi mencionado, erros similares se repetem até hoje.

Mesmo considerando aparentemente rudimentar o trabalho de Loie Fuller no que se refere aos aspectos coreográficos ou gestuais, Roubine (1982b) acentua positivamente o caráter expressivo do qual eram impregnadas suas performances à medida que ela se afastava da representação figurativa. E Roubine (1982b, p. 21) relacionou suas inovações às possibilidades da luz elétrica: "[...] a iluminação elétrica pode, por si só, modelar, modular, esculpir um espaço vazio, dar-lhe vida [...]". Levando

105 "A skilled electrician has to go ahead to cut the floor properly and to lay the wires. When this is done I can go to work. Sometimes I use ten lamps, sometimes sixteen, again twenty, and I have used as may as thrity four and it requires a skilled electrician to run each of them."

106 "Eight days later the general rehearsal occurred, which ended only at four o'clock in the morning, and still I had been unable to complete my programme, comprising five dances: 1 , the serpentine; 2 , the violet; 3 , the butterfly; 4 , a dance the public later called the 'white dance'. As a finale I intended to dance with illumination from beneath, the light coming through a square of glass over which I hovered, and this was to be the climax of my dances. After the fourth number my electricians, who were exhausted, left me there unceremoniously." 
em conta os avanços implantados pela produção de luz artificial, com a aplicação da eletricidade, ele afirmou que Fuller assumiu o papel de principal instrumento de estruturação e animação do espaço cênico. Mencionando vários espetáculos, sem qualquer ligação aparente, ele reconheceu: "[...] a luz torna-se elemento preponderante da cenografia". (ROUBINE, 1982b, p. 21)

Talvez fosse possível dizer que Loie Fuller contribuiu para uma assertiva que vem sendo aqui proferida: quando se reconhece a cena como uma expressão de visualidade, a luz se torna um elemento "preponderante" da práxis cênica. Essa preponderância é relativizada na presente abordagem para acentuar a importância da luz naquilo que Roubine (2003) chama de imagem cênica, considerando suas inúmeras referências à cena como uma imagem, o que caracteriza o ator, seu corpo, como parte da imagem cênica e, ele mesmo, como uma imagem Além disso, ele identificou ecos do pioneirismo de Fuller no teatro simbolista, assim como na teoria de Antonin Artaud (1896-1948) - segundo o próprio Roubine, de discutível precisão técnica, mas poderosamente sugestiva do uso da imaginação criadora na aplicação da luz no teatro.

A última apresentação de Loie Fuller ocorreu em Londres, no ano de 1927, e incluía o resultado de experimentações influenciadas pelo cinema, usando silhuetas e sombras. Ela denominou seu último trabalho de Balé Sombra (Shadow Ballet).

\section{ADOLPHE APPIA: A CENA IMERSA NA SOMBRA}

O interesse pela sombra aparece também nas investigações do já mencionado Adolphe Appia (1862-1928 - arquiteto e teórico suíço, estudioso do espaço teatral), nas quais se origina o trinômio ator-música-cena, incorporando uma compreensão inovadora da "verdade" na cena, ao vislumbrar novas funções para a luz, exigindo uma diferente relação entre o corpo do ator e o dispositivo cenográfico.

Appia introduziu o primeiro esboço moderno de uma teoria acerca das relações entre a luz e a práxis cênica, já no fim do século XIX e, ainda assim, os caminhos indicados pelos seus estudos foram apenas parcialmente abordados, em parte porque a luz permanece numa espécie de região nebulosa do conhecimento teatral. Algumas ponderações podem ser encaminhadas em direção a uma exegese do relativo desinteresse pela trilha teórica deixada por Appia. Seu próprio texto traz pistas para a compreensão de tal comportamento.

Em primeiro lugar, ao dispor o ser humano no centro da discussão, ele já elabora a provocação para movimentos teórico-práticos que tratam da corporificação do performer, como foi possível observar no decorrer do século XX e na 
atualidade. Seu reconhecimento do ator como corpo primordial da cena estabeleceu provocações. Desde Antonin Artaud (1896-1948), Jacques Copeau (1879-1949), passando por Jacques Lecoq (1921-1999) e Jerzi Grotowski (1933-1999), até Eugenio Barba, como exemplos, mesmo que a luz tivesse sempre papel decisivo na construção da cena, é compreensível que as ações, as reações e as relações humanas encontrassem destaque no pódio discursivo, tanto na teoria quanto na prática. No entanto, desde a acentuação do corpo como espaço no qual repercutem as emoções até a proposta de hegemonia da expressão física "autônoma" na práxis cênica, a luz permaneceu como elo entre a cena e o observador, corroborando a excelência da compreensão teatral de Adolphe Appia, que promove a consistente interação expressiva entre corpo e luz.

Em segundo lugar, sua investigação relacionava a luz para a cena de modo muito particular com a música. Expandir a compreensão do papel da luz na práxis cênica depois de Appia, por conseguinte, requer mais do que inferências meramente intuitivas no que se refere às relações entre a música, as artes visuais e a luz.

De todo modo, outras particularidades podem ser destacadas para que se compreenda o caráter parcial de determinadas abordagens. Já na década de 1930, Stanley McCandless (1897-1967) advertiu:

O design, ${ }^{107}$ ou mais especificamente, o planejamento e a execução da luz para uma montagem são frequentemente cobertos por um véu de mistério que se deve, sem dúvida, à falta de conhecimento, tanto dos limites quanto das potencialidades do problema. Esse mistério resulta, primeiro, da falta de filosofia fundamental de uma precedência na utilização da luz, como uma atividade do design, segundo, do primitivo equipamento empregado e, em terceiro lugar, da ausência de um plano simples, bem definido, que pode ser aplicado nas soluções de problemas da luz. ${ }^{108}$ (MCCANDLESS, 1984, p. 9-10, grifo e tradução nossos)

\footnotetext{
107 Uma tradução do termo design pode ser problemática principalmente devido ao uso indiscriminado do termo no Brasil, indicando a urgência da discussão dos processos que decorrem ou estão incluídos nas funções de um designer, especificamente de um designer trabalhando no teatro e mais, no design para a luz de espetáculos. No Brasil, essa discussão parece soar cada vez mais estranha e deslocada. Os processos de conceber e projetar a luz para a cena, incluindo planejamento e sistematização, parecem transitar no nível da idiossincrasia. Se cada um pode "fazer luz" usando seu jeito particular, sistematizar parece absurdo.

108 "The design, or more specifically, the planning and execution of the lighting for a production is often surrounded by a veil of mistery which is due, undoubtedly, to lack of knowledge of both the limits and the potentialities of the problem. This mistery arises first from the fundamental lack of philosophy of precedent in the use of light as a design medium, second, from the primitive equipment employed, and third, from the absence of a simple, well defined plan which may be applied to the solutions of lighting problems."
} 
McCandless (1984) apontava relevantes aspectos da discussão que, afortunadamente, deram lugar a estudos posteriores e efetiva repercussão no teatro norte-americano. Ainda que se depreenda de seu trabalho a busca por uma resposta aos limites financeiros que resultaram da grande depressão, na terceira década do século $\mathrm{XX}$, nos Estados Unidos da América, ele incorpora às suas reflexões a possibilidade da sistematização dos processos de conceber e planejar a luz para a cena. Os temas abordados por McCandless parecerão carecer de aprofundamento até hoje, se aquilo que ele chamou sabiamente "um método" para a luz no teatro for transformado, em "fórmula", "receita" ou "cartilha" aplicada superficialmente. Ele mencionou ainda um "véu de mistério", causado pela aplicação dos, então recentes, conhecimentos da eletricidade, além da possibilidade de abordagem da luz como elaboração estética no espetáculo.

Outra face dessa mesma questão se apresenta de modo diferenciado nos nossos tempos de democratização da informação: hoje, pode-se "baixar" na rede mundial de computadores cartilhas e manuais que orientam a operação de acessórios, instrumentos e sistemas de controle da luz para a cena, dissipando - parcialmente - o mistério e instruindo virtualmente muitos iluminadores. Infelizmente, tal nível de instrução é insuficiente para a educação de um designer.

Observando os estudos de Appia, registra-se que as questões estéticas representam parte importante do trabalho de um iluminador. Do campo das artes visuais, liderados pela noção de contraste, variados temas, como forma, textura, cor, massa, volume, equilíbrio, design-composição, projeto, luz e sombra, dentre outros, apresentam-se como problemas a serem estudados. Acentuando as especificidades de cada um dos temas, faz-se necessário um enorme empenho investigativo.

Por outro lado, a objetiva integração da música ao contexto da luz para a cena incorporou a noção de tempo, que se pode fazer acompanhar de ritmo, melodia, harmonia, timbre (cor tonal), integrando andamento, movimento, tema, textura musical, atmosfera. Uma intricada rede de grande relevância para o compositor, uma vez que cada um desses aspectos contribui para a qualidade sonora percebida pelo apreciador. O seu estudo particular, ligado ao conhecimento da história da música, pode ser imprescindível para o músico com interesse investigativo no seu próprio campo de trabalho, determinando grande profundidade técnica.

De todo modo, resta ao iluminador o alívio de não ser um músico com tal interesse, o que o desobriga do imenso volume de estudos que isso exigiria. No entanto, tais observações podem alertar que, ignorando a música, ou a natureza 
musical do espetáculo, a interação da música com a luz, ele desconsidera possibilidades de expressão e controle que podem contribuir para o seu trabalho.

E ainda, ao tratar as relações entre a luz, a sombra, o ser humano e o seu ambiente, Appia abriu um grande leque de possibilidades teóricas, em diversas áreas do conhecimento. Tratar de luz e sombra inclui lidar com a química, a física, a mecânica, assim como envolve a história, a filosofia e as artes visuais. Appia abordava a excelência da expressão visual na práxis cênica com especial atenção para as relações entre a cenografia e a luz. Isso gerou um primeiro princípio plástico-crítico através do qual ele tratou duramente a pintura usada para sugerir tridimensionalidade na cena, uma vez que, em sua opinião, essa técnica gerava um conflito ou negava a efetiva tridimensionalidade do corpo do ator, assim como do espaço cênico, resultando numa incongruência visual, espacial. Vale destacar um importante princípio norteador de suas observações:

Hoje, o ressurgimento do corpo como um meio de expressão essencial para a nossa cultura estética, é um conceito que se apossa de muitas mentes, anima a imaginação, e dá origem a diversos experimentos, não de igual valor, sem dúvida, mas todos voltados para a mesma reforma. ${ }^{109}$ (APPIA, 1962, p. 4, tradução nossa)

Estudando o ator como referência para a compreensão visual do teatro, ele elaborou uma teoria que via no palco um lugar expressivo da tridimensionalidade, o que indicava tratamentos da cena muito diferentes daqueles que se observava no seu tempo. A apreensão da totalidade e da grandeza da sua obra sugere que o leitor esteja capacitado, disposto ou, quando menos, seja flexível o suficiente para pensar a cena como uma ocorrência visual. Recomenda-se até ao interessado nas ideias de Appia a efetiva experiência na produção visual e, melhor, determinado grau de educação visual fundamentada na experimentação. Haverá maiores chances de afinidade com suas ideias se o leitor evitar o encarceramento dos textos na rigidez de molduras teóricas que se revelam incapazes de pensar visualmente. Na eventual ausência de tais habilidades e competências e/ ou na presença de preconceito ou desentendimento da cena como manifestação artística visual a leitura pode resultar superficial ou equivocada. Jean-Jacques Roubine (1998, p. 132-133) esboça um comentário que tangencia o problema:

109 "Today, the resurgence of the body as an expressive medium essential to our aesthetic culture is a concept which possesses many minds, animates the imagination, and gives rise to diverse experiments doubtless not all of equal value, but all directed toward the same reform." 
Se encenadores tais como Copeau ou Gémier saudaram Appia como um dos teóricos mais importantes do teatro moderno, e se Craig o tinha na mais alta estima, não se pode dizer que a sua notoriedade tenha ultrapassado os círculos especializados dos profissionais e historiadores.

Com efeito, um historiador envolvido com a práxis cênica e habilitado a construir uma reputação positiva jamais negligenciará, deixando Adolphe Appia fora do contexto teatral, dada a contundência do seu pensamento. Mas é compreensível que a face das suas ideias cuja compreensão implica em familiaridade com estudos visuais deixe de receber a devida atenção da teoria teatral. Afinal, a visualidade (e, principalmente, a aplicação da luz na cena) representa terreno praticamente não visitado pela vertente teórica do teatro. Além disso, as opiniões de Jacques Copeau (1879-1949) e Firman Tonerre Gémier (1865-1933) são importantes principalmente para registrar a repercussão positiva da teoria appiana, entre os diretores franceses. A obra de Appia, no entanto, fala por si mesma e deveria garantir amplo espaço de estudo. Pode-se observar nos comentários do próprio Roubine (1982b, p. 134) a categoria do reconhecimento das suas proposições: “[...] um dos primeiros a tomar consciência dos extraordinários recursos que a iluminação elétrica põe a disposição do encenador". Nesse depoimento fica, ao menos, caracterizada a possibilidade de incorporação de uma teoria especificamente voltada para questões visuais da cena, envolvendo conceitos importantes:

Essa teoria cenográfica que repousa essencialmente em princípios arquitetônicos (estruturação das três dimensões do espaço cênico, modulação das formas e dos volumes, cheios e vazios, exploração dos potenciais da verticalidade e da horizontalidade, jogando com os planos oblíquos, ou contra eles...) levou Appia a diminuir, talvez até a sacrificar a parte da cor na imagem cênica. (ROUBINE, 1982b, p. 137-138)

Nesse comentário de Roubine, por conseguinte, encontram-se relevantes elementos para discussões da obra de Appia: além da inclusão de uma teoria cenográfica, podem ser considerados indícios para uma teoria da interação da luz com a cena, incluindo o sacrifício da cor e a investigação da "imagem cênica". A teoria teatral poderia alcançar maior relevância, reparando-se a grave lacuna no que se refere à especificidade da luz na cena como um campo de problematizações. Afinal, ainda que seja possível identificar papéis determinantes da luz em diversificados e importantes documentos da história do teatro, como tem sido sublinhado ao longo do presente trabalho, Appia introduziu um tratamento teórico 
particular, indicando o estudo do pensamento visual como estratégia para a resolução de problemas teatrais. E mesmo que seu trabalho acentue em grande parte críticas à cena wagneriana, ${ }^{10}$ ele deixou espaços para a observação da sua obra como teoria abrangente. Mesmo registrando que alguns leitores considerariam sua crítica pretensiosa levando-se em conta a reputação de Wagner, ele afirma: "Se não fui dissuadido diante dessas considerações foi apenas porque não conheço nenhuma maneira de comunicar tais convicções, que me parecem de considerável significado para a arte do teatro. ${ }^{111}$ (APPIA, 1962, p. 7, tradução nossa)

O breve comentário de Jean-Jacques Roubine acerca da cor traz um exemplo da amplitude radical das ideias de Appia. O que ele propôs não foi o sacrificío da cor na imagem cênica e, sim, o reconhecimento do seu elevado potencial expressivo quando ela é incorporada aos elementos cenográficos através da luz. Em lugar da informação cromática fixada nas pinturas que pretendiam sugerir tridimensionalidade, Appia acentuou uma enorme fluidez visual derivada da interação entre a luz e a cena em decorrência da aplicação sistematizada da cor, o que possibilitaria a elaboração de uma tridimensionalidade cênica integral e orgânica. Essa é uma sensível demonstração da sua abordagem da cena como um pensamento visual.

Um relato de Richard C. Beacham (1994) (autor, professor da Universidade de Warwick e professor visitante da Universidade de Yale) revela como o próprio Appia, já na adolescência, começou a desenvolver as preocupações visuais que mais tarde fundamentariam suas convicções sobre o teatro:

[...] Appia construiu, com um colega da escola, um pequeno teatro de papelão, mas ele discordava do uso que o colega fazia de recortes para o cenário. Ele os achava sem sentido e insistia em usar objetos reais no palco. A disputa foi fundamental e irreconciliável: culminou com a solene e deliberada destruição do teatro de brinquedo e todo o incidente funcionou como uma precursora miniatura da futura relação de Appia com o teatro real. ${ }^{112}$ (BEACHAM, 1994, p. 8, tradução nossa)

\footnotetext{
110 Muito influenciado pela obra e pela teoria de Richard Wagner (1813-1883), tanto no que se refere às composições do artista alemão, quanto à sua teoria, desenvolveu sua própria compreensão da parceria entre os diversos aspectos que compunham uma obra teatral.

111 "If I have not been dissuaded by these considerations, it is only because I know of no other way to communicate those beliefs which seem to me to have considerable significance for the art of the theatre."

112 "[...] Appia and a schoolmate.designed a small cardboard stage but fell out over the friend's use of conventional painted cut-outs for the scenery. Appia found these meaningless and insisted on placing real objects on stage. The dispute was fundamental and irreconcilable: it ended with the solemn and deliberate destruction of the original toy theatre, the whole incident a precursor in miniature of Appia's later relationship to the real theatre."
} 
Beacham (1994) afirma que ele sempre demonstrou interesse por atividades teatrais, mas a família calvinista o mantinha distante do teatro, restando-lhe inquirir os amigos que tinham permissão para assistir espetáculos, sobre que se via por lá. A permissão para envolver-se com a arte ficou limitada ao estudo da música, no Conservatório de Leipzig, sob a orientação do renomado maestro Hugo von Senger (1835-1892). Em 1878 Appia foi autorizado pelos pais a visitar a Opera local, onde assistiu Fausto, de Gounod, o que reforçou seu desagravo aos cenários de telões pintados, assim como ao arranjo espacial que decorria dessa técnica, como ele registrou: "Eu estava consciente de que os cenários eram frágeis e de que o piso do palco era chapado". ${ }^{113}$ (APPIA apud BEACHAM, 1994, p. 8, tradução nossa) Continuando os estudos da música, ele esteve em Paris, entre 1884 e 1886, seguindo depois para Dresden, onde permaneceu entre 1886 e 189o. Nesses períodos, Appia desenvolvia seu pensamento sobre a cena, influenciado pelas ideias da cooperação entre as artes, derivada da obra teórica de Wagner, notadamente pelo conceito traduzido como "obra de arte total" que pode ser lido "obra de arte integral" (Gesamtkunstwerk).

É importante dizer que, se a obra musical e a teoria de Wagner deixavam profunda impressão positiva em Appia desde que assistiu Parsifal em 1882, apontada pela crítica como avançado estágio nos espetáculos wagnerianos, ele se sentiu decepcionado pelo uso tradicional do espaço cênico. A desaprovação de montagens com essa tendência é perpassada por uma nova maneira de conceber as funções da luz. Um dos mais importantes aspectos da sua abordagem já é exposto no início do seu discurso, assentando as bases da sua teoria:

Toda obra de arte deve conter uma relação harmoniosa entre sentimento e forma, um equilíbrio perfeito entre a ideia que o artista deseja expressar e os meios que ele usa. Se um dos meios nos parece claramente desnecessário para a expressão da ideia, ou se a ideia do artista - o objeto de sua expressão - nos é comunicada apenas imperfeitamente através dos meios que ele emprega, nosso prazer estético é enfraquecido, se não destruído. ${ }^{114}$ (APPIA, 1962, p. 10, tradução nossa)

Como se pode observar, Appia acreditava numa obra de arte norteada pelo conceito de unidade, questionada no decorrer do século XX, e confrontada pelas

113 "I was conscious of the flimsiness of the settings and the flatness of the stage floor."

114 "In every work of art there must be a harmonious relationship between felling and form, a perfect balance between the idea which the artist wishes to express and the means he uses to express it. If one of the means seems to us clearly unnecessary to the expression of the idea, or if the artist's idea - the object of his expression - is only imperfectly communicated to us by the means he employs, our aesthetic pleasure is weakened, if not destroyed." 
rupturas que defendem a fragmentação, a descontinuidade e a justaposição praticadas em iniciativas não realistas, para as quais a unidade buscada por ele pode soar ultrapassada, até idealista e/ou romântica. Apesar disso, sua obra ganhou repercussão entre especialistas e lhe garantiu reputação de inovador, precisamente devido à sua crítica às práticas do século XIX que, em sua opinião, incluíam primeiro a acentuação do ilusionismo pictórico e depois a representação detalhista da realidade, uma vez que ambas podem redundar em falsos espaços cênicos.

A despeito do grande respeito pela obra musical e teórica de Wagner, ele criticava o espetáculo produzido pelo compositor, considerando-o aquém do pensamento teórico e da harmoniosa conexão dos elementos do seu wort-tondrama. Sobre a expressão alemã, Beacham (1994, p. 38, grifo e tradução nossos) comenta:

O termo foi cunhado por seu amigo Houston Stewart Chamberlain: Ver Volbach, Adolphe Appia, p.35-6 e Bablet-Hahn (ed.), Oeuvres Complètes, vol. I, p. 444, nota 7. Na primeira página de A montagem do drama wagneriano [La mise en scène du drame wagnérien], Appia acentua que usa a expressão alemã WORTTONDRAMA - um drama, portanto, em que o poeta utiliza tanto a palavra, quanto a música. Esse tipo de drama é de alguma forma, uma síntese do Wort-drama, o 'drama em palavras', a peça propriamente dita, e o Ton-drama, o único e verdadeiro 'drama musical', no qual o poeta usa a música apenas, como Beethoven em Coriolan, na Sinfonia $n^{0} .3$ Heroica, entre outras obras. Assim como Berlioz em sua Symphonie Fantastique e Liszt nos Poemas Sinfônicos. Nunca será demais repetir quantas vezes Wagner se opôs fortemente à aplicação da expressão 'drama musical' para se referir ao seu trabalho para o palco. Como não temos em francês um equivalente para WORT-TONDRAMA, vou usar a expressão 'drama wagneriano' [drame wagnérien] ou 'drama do músico-poeta' [drame du poète-musicien], mas gostaria que o leitor tivesse em mente que, por 'drama wagneriano', não me refiro apenas à obra de Richard Wagner, mas, em geral, à nova forma de drama criado por ele. ${ }^{115}$

115 "The term was coined by his friend Houston Stewart Chamberlain: see Volbach, Adolphe Appia, p.35-36, e Bablet-Hahn (Ed.), Oeuvres complètes, Vol. I, p. 444, nota 7. On the first page of La mise en scène du drame wagnérien, Appia notes that he uses 'the German term WORT-TONDRAMA' - a drama, thus, in which the poet uses word and music alike. This kind of drama is in some way a synthesis of the Wort-drama, the 'drama in words', the play proper, and the Ton-drama, the only true 'music drama', in which the poet uses only music, as Beethoven in Coriolan, The Heroic Symphony, etc. Berlioz in his Symphonie Fantastique. Liszt in it's Symphonic Poems. One cannot repeat often enough that Wagner strongly objected to having this term of 'music drama' applied to his stage-work. As the French do not have an equivalent for WORT-TONDRAMA, I shall use the term 'Wagnerian drama' [drame wagnérien] or 'drama of the poetmusician' [drame du poète-musicien], but I would like the reader to keep in mind that 
O próprio Appia (1962, p. 28-29, tradução nossa) resume: "Os elementos constitutivos do drama poético-musical pertencem a dois grupos distintos: as palavras e os sons, transmitidos pela voz dos atores e pela orquestra, e os elementos visuais da montagem". ${ }^{116}$ Appia acentua seu interesse pela música, justificando-o na convicção de uma forte afinidade entre ela e a luz.

Ele pondera, citando Houston Stewart Chamberlain: "Apolo era, não apenas Deus da música, mas também da luz". ${ }^{117}$ (CHAMBERLAIN apud APPIA, 1962, p. 72 , tradução nossa) Appia compreendia que luz e música compartilham grande flexibilidade, permitindo amplitude expressiva desde o mais sutil até um extraordinário e grandioso momento. Parte do seu empenho crítico para aproximar-se do novo "drama do músico-poeta", questionando as montagens tradicionais e, em particular, as montagens da obra de Wagner, pode ser observado em A música e o espetáculo (La musique et la mise en scène). ${ }^{118}$ Escrito entre 1892 e 1897, e publicado dois anos depois, numa tradução alemã (Die musik und die inscenierung), assinada pela princesa Elza de Cantacuzène, é hoje um livro raro como exemplar impresso. A cópia usada no presente trabalho pode ser encontrada na rede mundial de computadores.

Ele escreveu outros dois textos, A montagem do drama wagneriano (La mise en scène du drame wagnerien), em 1891 e A obra de arte viva (L'oeuvre d'art vivant), publicado em 1921, nos quais se pode confirmar sua presença como primeiro grande teórico moderno a concentrar esforços na investigação de presenças da luz na cena. Aqui serão citados, prioritariamente, trechos de $A$ música e o espetáculo; não somente o original, mas também a tradução inglesa, de Robert W. Corrigan e Mary Douglas Dirks (1962), na qual eles usaram tanto o original francês - disponível na Schweizer Theatersammlung, Landesbibliothek, em Berna, Suíça - quanto a versão alemã. Essa edição inglesa de 1962 traz um prefácio original escrito pelo próprio Appia, em 1918.

A escolha de A música e o espetáculo é sintomática para o método aqui aplicado, pois identifica um momento ou fragmento da sua obra que sublinha as interações entre a luz e a cena, no caso, apresentando uma interação particular com a música. Como já foi dito acima, a obra de Wagner estabelece relações com outros composi-

\footnotetext{
by 'Wagnerian drama' I do not only refer to the work of Richard Wagner, but, more generally, to the new form of drama created by him. Trans. Peter Loefer. Staging Wagnerian Drama, p. 89."

116 "The constituent elements of word-tone drama fall into two distinct groups: the words and tones as they are transmitted by the actors'voices and the instruments of the orchestra, and the visual elements of the production." 117 "Apollo was not only the god of song, but also of light."

118 Para aqueles leitores interessados numa abordagem da sua obra, em língua portuguesa, Cibele Forjaz traçou um panorama que incorpora competência de pesquisadora e paixão de quem pensa visualmente a cena, na sua dissertação de mestrado, mencionada na introdução deste trabalho.
} 
tores, como os citados Ludwig von Beethoven (1770-1827), Hector Berlioz (1803-1869) e Franz Liszt (1811-1866). Se for tomado como exemplo o Coriolano, ${ }^{119}$ [Coriolan] de Beethoven, pode-se levar em conta outras obras de referência como Coriolano, de Shakespeare e até o Coriolano que aparece na obra de Plutarco (ca. 46-12o d.C.), Vidas de nobres gregos e romanos.

Pode-se dizer que Beethoven "conta a história" - escrita por Shakespeare, provocado por Plutarco - de um general romano que luta contra o infortúnio causado pela inconsequência do seu próprio orgulho. Dessa assertiva deriva um questionamento, acentuando-se que Beethoven teria permitido a invasão da estrutura da sonata ao privilegiar o interesse em contar a história. Para o apreciador, ao contrário disso, pode impressionar a singularidade da obra, capaz de narrar com paixão permeada de precisão e controle a história de Coriolano. Os dois aspectos podem, por si só, justificar uma profunda relação cênica entre a música e a luz.

Um estudioso da música ou, em particular da obra de Beethoven, poderá estabelecer análises comparativas - com acuidade técnica não disponível a simples apreciadores - que podem incluir outras obras, principalmente do mesmo compositor. Para o iluminador torna-se necessária a aproximação com a estética, com a forma, com a poética de Beethoven para promover subsídios, fundamentação, ouvindo, não somente a abertura em questão, mas outras peças, por exemplo, Fidelio,' considerando que essa é a única ópera escrita pelo compositor.

Pode-se compreender o fascínio de Appia pela música quando são observados o controle e a precisão, caros para sua abordagem visual, constatando-se a relevância dessas variáveis na contribuição da luz para o teatro. Diante de um projeto para Coriolano, a Abertura pode ser esclarecedora para o iluminador, observada a consistência dos temas musicais que elaboram a saga do general romano, as súplicas da sua mãe que - como Appia acentuou - não são narradas com palavras, mas expressas nas frases sonoras através da elaboração de atmosferas, no contraste entre o cortante dos violinos e a suavidade e maciez arredondada dos sopros, mais em congruência com os violoncelos. A importante relação entre a música e a cena, presente na compreensão de Appia, sugere elos entre o modo como a luz pode contribuir para as atmosferas de uma montagem, promovendo parcerias e trocas esteticamente produtivas.

119 Opus 62 em dó menor, para duas flautas, dois oboés, dois clarinetes, dois fagotes, duas trompas, dois trompetes, tímpanos e cordas, escrita em 1807 e incluída como introdução a uma apresentação da peça Coriolan, de Heinrich Joseph von Collin (1771-1811), dramaturgo vienense com o qual Beethoven pretendia trabalhar, tendo-o como libretista, escrevendo anualmente uma ópera, no Teatro Imperial de Viena. A parceria não aconteceu, pois Beethoven não conseguiu fechar o contrato, mas nos rendeu sua Abertura para Coriolano. 
De acordo com Arnold Aronson (1991, p. 3, tradução nossa), Appia investiu na sugestão, na simplicidade, na abstração e na grandeza, propondo um dispositivo cênico tridimensional, escultural, capaz de unificar o ator e a cena como espaço teatral: "O resultado é uma imagem visual em concordância com o pensamento do autor". ${ }^{20}$ A plasticidade explícita das suas proposições, portanto, mantém a presença da dramaturgia - poético-musical - como um aspecto provocador do espetáculo, afirmando o valor da visualidade e, consequentemente, do binômio luz-sombra. Ainda assim, pode-se observar que o presumível poder do dramaturgo se relativiza:

Segue-se, portanto, que o drama (tal como produzido no palco), não somente é a mais complexa de todas as artes, mas também a única na qual um dos elementos básicos [a montagem/o espetáculo] não pode ser considerado um meio de expressão controlado pelo dramaturgo, uma condição que diminui de modo agudo a integridade do drama, como uma forma de arte, relegando-o a um status inferior. ${ }^{121}$ (APPIA, 1962, p. 11, grifo e tradução nossos)

O texto enfrentava, então, uma crise imposta pela incompletude inerente à sua própria natureza, enraizada na sua condição de estágio pré-cênico, de momento transitório a caminho do palco. Appia compreendia a cena como duas partes interligadas: o elemento animado - o ator, a forma viva do corpo humano - e os elementos inanimados (mesmo que postos em movimento), que ele reduz a três, para a sistematização da sua teoria: a luz, a organização espacial do dispositivo cenográfico - la plantation - e a pintura, os telões. Ele procurou demonstrar, então, a incongruência da pintura, dos telões cenográficos que, como objetos bidimensionais concebidos para criar ilusão de volume geravam sérios conflitos com a efetiva tridimensionalidade do corpo do ator. Era indispensável, portanto, investir em um novo arranjo espacial da cena cujos elementos inanimados já fossem construídos como corpos tridimensionais.

Appia (1962, p. 22, tradução nossa) ponderou: “[o cenário pintado] é incapaz de revelar qualquer realidade viva e expressiva por si mesmo e perde o poder de significação à medida que todo o resto da cenografia desempenha uma função ativa na

120 "The result is a visual image at one with the playwright's thoughts."

121 "It follows therefore that the drama (as produced on stage) is not only the most complex of all arts, but also the only one of which one of the basic elements may not be judged as a medium of expression in the dramatist's control, a condition acutely diminishing the integrity of drama as an art form and relegating it to an inferior status." 
cena". ${ }^{122}$ Reconhecendo que o cenário figurativo pintado ocupava de forma predominante o teatro do seu tempo, desde o início da apresentação da sua teoria ele destacou a luz como o mais expressivo entre os elementos inanimados da cena. No entanto, projetá-la sobre cenários pintados significava promover a mera função de iluminar, para tornar visível, criando "falsas realidades". Isso destruiria a harmonia orgânica exigida para a integridade da arte teatral, que depende da presença do ator, sem a qual os demais aspectos da montagem permaneceriam alienados do drama (compreendido, nesse caso, como expressão artística de conflitos humanos). O corpo vivo do ator exige funções ativas da luz.

Ficava indicado o caminho para a produção de um dispositivo cenográfico vivamente integrado ao espetáculo e cujo objetivo se afastasse da ilusão promovida por elementos pictóricos bidimensionais: "[...] é apenas através do poder da luz que o cenário pode tornar-se verdadeiramente expressivo, e isso deve ser considerado na sua construção". ${ }^{123}$ (APPIA, 1962, p. 64, tradução nossa) Como já foi dito, o dramaturgo produz sua obra com o olhar na cena; além de discutir a autonomia do autor, Appia elaborou indicações teóricas de uma cena integralmente concebida e construída sob os pressupostos da sua relação com a luz. A verdadeira expressão de uma montagem somente seria alcançada quando efetivada essa relação. Ele justifica, então, espaço para a discussão da luz, ao descartar o meio termo entre o que denomina "realização plástica positiva" (o dispositivo cenográfico tridimensional, não necessariamente figurativo) e os telões pintados. (APPIA, 1962, 1986) Appia (1962, p. 46, tradução nossa) ratifica, portanto, a função ativa da luz na nova cena:

[...] o que, senão a luz, dá essa magnífica unidade ao espetáculo que contemplamos cada dia, permitindo-nos viver através dos nossos olhos. | Sem essa unidade, distinguiríamos apenas vagamente o significado das coisas e nunca sua expressividade, pois, para que as coisas sejam expressivas, elas devem ter forma, e forma sem luz comunica apenas o sentido do tato. ${ }^{124}$

\footnotetext{
122 "[the scene painting] is incapable of revealing any living and expressive reality by itself, and it loses its power of signification to the extent that the rest of the setting plays an active part in the scene."

123 Da tradução inglesa: "[...] it is only through the power of the lighting that the setting can become truly expressive, and this fact must be taken into account in its construction".

124 "[...] what is it if not light that gives that wonderful unity to the spectacle we contemplate each day, allowing us to live through our eyes? / Lacking this unity, we should be able to distinguish only dimly the meaning of things, and never their expressiveness; for in order that things be expressive, they must have form, and form without light communicates only to our sense of touch."
} 
Em uma nota de rodapé, ele chamou a atenção do leitor: "Quando me refiro à luz, é evidente, quero dizer a atividade da luz, não apenas "visibilidade". 125 (APPIA, 1962, p. 46, tradução nossa) Sucinta ponderação que congrega toda a sua teoria e que poderia repercutir positivamente em projetos de luz para a cena, até hoje. Essa "atividade" da luz estaria ligada às chamadas funções ativas que ela pode desempenhar no espetáculo. Ou seja, não bastaria projetar luz colorida, gráfica, recortada, em movimento mecânico constante, pois ainda assim o espectador poderá ter apenas o resultado de banalização da alta tecnologia, sem que isso repercuta numa práxis cênica com força visual expressiva. Aliás, mesmo os envolvidos nas diversificadas iniciativas, cujos fundamentos se encontram na desconstrução da unidade, poderiam "ouvir" Appia. Afinal, sem familiaridade estética com a luz eles podem até gerar, acidentalmente, unidade. Mesmo que isso seja pouco provável, caso ocorresse a função ativa da luz, estaria transformada numa armadilha, pois negaria ou trairia a intenção de desconstruir a unidade.

Ainda que sua preocupação com a luz se manifeste em toda a primeira parte do seu livro, voltada para a montagem propriamente dita, Appia (1962, p. 72, tradução nossa) reservou um espaço específico para aspectos da luz, e depois para a pintura, onde as funções da cor ganham grande destaque. Reafirmando as relações entre a luz e a música, ele acentua: “[...] ambas, [a luz e música] são dotadas de incomparável flexibilidade que as permite percorrer consecutivamente todos os graus de expressão, do mais simples ato de presença até o mais intenso transbordar de emoções". ${ }^{126}$ Importa relacionar tal flexibilidade expressiva com a intenção do autor de propor alguma sistematização para a aplicação da luz, acentuando os benefícios do estudo das possíveis relações entre o ator, o arranjo espacial (la plantation) e o texto (poético-musical).

Partindo dessa relação dinâmica, Appia sugeriu princípios que definiram sua abordagem da luz teatral. Destaco observações que incorporam provável sistematização, como a noção da "quase simultaneidade" inerente à composição do arranjo cênico e da luz, dando pistas da interação dinâmica entre os dois aspectos, um dependendo do outro. Além disso, é importante registrar a compreensão de Appia do arranjo espacial - ou dispositivo cenográfico - que deveria apresentar respostas particulares a cada espetáculo, descartando os cenários que se repetiam, ficando evidenciada sua indicação de uma intervenção flexível da luz, que a tornasse capaz de interagir especificamente com cada acontecimento e cada cena.

125 "By light, of course, I mean the activity of light, not simply 'visibility'."

126 "Both elements have an extraordinary flexibility which permits them to run through all modes of expression consecutively, from a simple statement of existence to the most intense overflow of emotion." 
Isso quer dizer que o posicionamento fixo dos instrumentos - denominados refletores - pode determinar limitações para que a luz intervenha de acordo com as exigências de cada momento. Em tais observações, reside uma importante crítica aos sistemas mais comumente encontrados nos teatros do seu tempo, nos quais ele apontava a ausência de mobilidade e de precisão.

Appia analisava os mencionados sistemas usando como critério a relação entre as características técnicas de cada instrumento, sua posição no palco e a função que ele esperava dos mesmos, apresentando os quatro modos de sistemas de iluminação geralmente usados: uma vara horizontal atrás e acima da boca de cena para iluminar os telões pintados, complementada por luzes dispostas nas coxias e no piso do palco, com o mesmo objetivo; a ribalta, que ele chamou de "monstruosidade", para iluminar os atores e também os cenários, projetando uma luz frontal, de baixo para cima; dispositivos móveis que permitiam acesso e manipulação para fachos de luz precisos, ou diversificadas projeções; e a luz por transparência, geralmente produzida por instrumentos colocados atrás dos telões pintados, para interagir com elementos cenográficos transparentes (ou translúcidos).

Em sua opinião, os espetáculos mostravam como a interação técnica dos aparatos poderia ser complicada e até impraticável, se fosse negligenciada a precisão, resultando em contradição que destrói a potencialidade da harmonia. Ele elaborou uma problematização: "Como conciliar, de fato, uma luz destinada a iluminar os telões verticais, que não ilumine outros elementos [cenográficos] dispostos entre a fonte de luz e os mencionados telões e painéis verticais?". ${ }^{127}$ (APPIA, 1962, p. 95, tradução nossa)

Sua crítica concentrava-se na imprecisão, tanto no que se refere às limitações de cada instrumento quanto ao seu uso simultâneo, que produziam resultados contraditórios, como no caso da ribalta, responsável pela exposição indiscriminada de tudo que estivesse ao seu alcance. A postura de Appia indicava certa sistematização que procurasse estabelecer ligações entre a técnica e as funções expressivas da luz, das quais ele apontava duas principais: a luz poderia ser "difusa", ou seja, aquela que preencheria o ambiente; ou a "ativa", que produziria focos específicos. Tais funções baseavam-se na observação da luz do sol, considerando os mais variados resultados da sua interação cotidiana com o ambiente. Tratava-se de uma convenção muito radical, se for levado em conta que a luz passiva e a luz ativa, observadas à luz do sol, em momentos e locais diferenciados, podem ser

127 “Comment concilier, en effet, une lumiére destinee à eclairer les toiles verticales et qui n'en frappe pas moins les objets placés entre elles, avec une lumiere destinée à ces objets et qui n’en frappe pas moins les toiles verticales?" 
aplicadas simultaneamente na cena, do modo como o artista considerar indicado para a construção visual do seu espetáculo.

Appia até considerava que os instrumentos disponíveis em posições fixas nos teatros, poderiam operar na produção da luz difusa, mas apontava a necessidade de estudos do seu posicionamento, uma vez que a nova práxis cênica por ele proposta descartava a disposição sucessiva de pinturas verticais paralelas, para as quais as posições fixas dos instrumentos de luz foram concebidas. Para a luz ativa ele demandou pesquisas que investigassem maior eficiência técnica dos instrumentos, incluindo sua mobilidade e manuseio, para permitir flexibilidade no atendimento das novas proposições dos dispositivos cenográficos concebidos a partir de então, diretamente relacionados às particularidades de cada espetáculo, mudando radicalmente a geografia da cena, a partir da introdução do verdadeiro [real] tridimensional. ${ }^{128}$ (Figuras 114 e 115)

Tal flexibilidade deveria também alcançar as relações técnicas entre a luz difusa - através da qual se estabeleceria "visibilidade" e a luz ativa, que - ainda segundo Appia - deveria expressar a noite, a lua, uma tocha, e até o "sobrenatural". A inclusão do sobrenatural abria enormes espaços para a aplicação da luz ativa, indicando saídas para a limitação imposta pela proposição figurativa - ou realista. Além disso, preocupado com o controle da intensidade da luz, ele indicou o uso de telas-filtro que apresentassem variados graus de transparência, com o objetivo de evitar a exposição excessiva de elementos cenográficos, ou mesmo de atores que se aproximassem dos instrumentos destinados à luz difusa.

A estratégia era criar diversificadas variações visuais no espetáculo, contando com a mobilidade e com a possibilidade de adaptações dos instrumentos aplicados à luz ativa, além de alguma organização prévia do sistema elétrico do teatro, incluindo o aparato da iluminação. Isso indicava esboços do pensamento que originaria, na década de trinta do século XX, o theatre lighting design, em busca da efetiva expressão visual da cena, uma vez que o arranjo espacial e a luz deveriam atuar em constante interação, criando uma espécie de atuação "invisível" da luz.

Appia também parte de uma compreensão muito inovadora do ator, emprestando-lhe um papel até então não mencionado, para fundamentar suas convicções acerca do espetáculo:

[...] o ator é uma massa sólida que não pode ser iluminada por uma imitação da luz; para ter luz no palco um ou outro deve ser eliminado [o ator ou a pintura de telões, que ele considera

128 Cf. Figuras 139 e 140, para comparação entre a proposta de Appia e o cenário da montagem do Bayreuth. 
imitação da luz]. Se dispensamos o ator, o drama é eliminado, [...]. Portanto, a pintura deve ser sacrificada. ${ }^{129}$ (APPIA, 1962, p. 75, tradução nossa)

Em primeiro lugar, reduzida a "massa sólida", uma diva sentir-se-ia ofendida. Nessa constatação, entretanto, Appia estava defendendo o ator na sua condição de corpo que afastava as convenções da pintura, da bidimensionalidade:

O arranjo cenográfico tem [...] apenas uma maneira de se transportar para a cena: através do Ator. Sem ele [o ator], o drama não existe, e, sem a sua influência sobre outros fatores representativos, o espetáculo permanece estranho ao drama. É ele quem traduz o Arranjo Espacial, a Iluminação e a Pintura, em uma linguagem que o drama possa compreender e na qual o texto poético-musical confie. Ele é o intérprete da música diante de um quadro inanimado. ${ }^{130}$ (APPIA, 1986, p. 76, tradução nossa)

O conceito de organismo unificado, no qual Appia baseou sua ideia de espetáculo, dispensava, portanto, a pintura figurativa, uma vez que a luz nela imitada estabeleceria sérios conflitos visuais com a luz ativa, viva, definidora da cena. O próprio pintor (cenógrafo) deveria incorporar certas limitações para vincular seu trabalho ao palco, pois a luz viva da cena destruiria, como diz Appia, os princípios que regulavam o uso da cor na pintura para o teatro. O arranjo cromático, assim como as formas da pintura figurativa, ambos perdem seu sentido e valor expressivo, pois não permitem a interação com os elementos "vivos" da cena: não somente o ator, mas também os elementos (tridimensionais) inanimados. Isso indicava a criação de novos princípios, que afastassem a imposição de um caráter "quimérico" para a luz, fazendo-a renunciar à representação figurativa. Appia considerava que a diferença entre as convenções que regiam a pintura e a cena levariam a primeira a submeter-se à expressão tridimensional da outra, já manifestada no seu elemento vivo principal, o ator.

Dessa relação derivaram questões que merecem observação. O pintor de cenários, afirmava Appia, deveria abrir mão da presença do ser humano, uma vez que

\footnotetext{
129 "[...] the actor is a solid mass, which cannot be lighted by imitation light; in order to have light on the stage, one or the other must be sacrificed. If we dispense with the actor, the drama is effaced, [...]. Therefore, the painting must be sacrificed."

130 “La partition n'a, [...], qu'une voie pour se transporter sur la scene: c'est l'Acteur. Sans lui le drame n'existe pas, et sans son influence sur les autres facteurs representatifs la mise en scene reste etrangere au drame. C'est lui qui traduit pour la Plantation, l'Eclairage et la Peinture, en un langage qu'ils puissent comprendre, ce que le texte poetique-musical lui a confie. Il est l'interprete de la musique aupres du tableau inanime.
} 
na pintura ele seria reduzido a uma representação fictícia - como o próprio Appia qualifica - enquanto que na cena o ator se apresentaria vivo e na condição de corpo principal. O artista que fazia uma obra pictórica para o teatro estava pronto para refrear suas próprias visões, atendendo aos caminhos apontados pelo dramaturgo. E o poeta-músico trazia suas visões para a cena através da própria música, que detinha posição hierárquica superior, promovendo controle do poeta sobre todos os outros elementos do espetáculo, incluindo a pintura.

Fora da cena um pintor impregnava de visões, de imagens pessoais, seus suportes, enquadrando-os à "imobilidade" que Appia via na pintura. O pintor-cenógrafo, entretanto, perdia tal poder, uma vez que deveria se render aos pressupostos encaminhados pela dramaturgia. O novo espetáculo, por conseguinte, impunha à pintura a exclusão da representação pictórica do ser humano, evitando assim conflitos com a imagem viva do ator, em movimento na cena. E, no caso específico do wort-tondrama, o drama poético-musical, a música teria enorme contribuição naquilo que seria visto na cena, provocando atmosferas. Para Appia (1962), a mobilidade mecânica da pintura de cenários era uma incongruência, uma vez que atacava e subtraía um dos maiores poderes do pintor, ou seja: o direito de observar seus objetos ou temas, selecioná-los e fixá-los na bidimensionalidade imóvel de um suporte que, assim como os instrumentos e materiais, refletem prioritariamente suas escolhas e decisões.

Isso sugere uma nova postura, assumida por Appia (1962, p. 100, tradução nossa):

Desse modo, torna-se necessário estudar mais detalhadamente a interação da iluminação, no que se refere à cor, para saber se a pintura, no sentido comum da palavra, mantém um papel distinto no novo espetáculo, fora do conceito geral de imagem cênica [quadro]. ${ }^{131}$

Mais que listar regras, ele indicou investigações, reflexões norteadas pela aplicação da luz, que apontem caminhos para o uso da cor na montagem do drama poético-musical. Na opinião de Appia, portanto, a cor que representava a luz na pintura figurativa, tornou-se desnecessária; ao contrário disso, a luz incorporaria à cor usada na cena as características vivas que a imobilidade da pintura lhe subtraíra. Além disso, ele ponderou que a luz pode incorporar cor ao espetáculo, não somente através de acessórios, como filtros de vidro colorido, mas, também,

131 “Il devient donc necessaire d'étudier plus en detail le jeu de l'eclairage au point de vue de la couleur pour savoir si la peinture, au sens ordinaire du mot, conserve un role distinct de la nouvelle mise en scène, en dehors de la conception generale du tableau scenique." 
das características particulares de cada instrumento ou fonte (temperatura de cor). O que Appia (1962, p. 97, tradução nossa) procurava esclarecer pode ser observado num pequeno fragmento do seu texto: “[...] a cor já não depende de telas verticais para exteriorizar-se, [...] ela está tão estreitamente ligada à luz, que é difícil separar uma da outra". ${ }^{132}$ A relação intrínseca entre luz e cor pode, até hoje, servir de alerta para o iluminador.

Appia (1962, p. 32, tradução nossa) discordava do teatro do seu tempo também no que se referia às relações entre a luz e os objetos da cena: “[...] para cada um dos objetos é designada uma cor e, finalmente, a luz é usada para torná-los mais ou menos visíveis." ${ }^{33}$ E quando a ilusão buscada pela cena incluía diferentes momentos do dia, procurando expressar esses momentos com mudanças convencionais de cor e intensidade na luz, o resultado não satisfazia, uma vez que a luz "viva" não interagia com a luz pintada no cenário, produzindo falso tratamento cromático. Tal constatação estava ligada à ilusão cênica ideal defendida por Appia (1962, p. 32, tradução nossa): "A ilusão criada por uma obra de arte não se destina a nos iludir acerca da natureza das emoções ou objetos, em sua relação com a realidade, e sim, para nos levar tão completamente a visão do artista, de modo que ela pareça ser a nossa própria". ${ }^{134}$

Ele apontava o crescente gosto pelo sensacional - aparatoso - como responsável pelos investimentos na pintura figurativa e nos artifícios decorativos, desconsiderando-se as funções ativas da luz, que era usada somente para - mais ou menos - iluminar. Appia aplicou também a expressão "suprema ilusão", na qual ator e cenário abrem mão de características figurativo-representativas, buscando uma presença em comum na cena. Se o ator perde em liberdade, quando interage com elementos musicais - como a duração - que ganham considerável importância estética, operando como aspectos responsáveis pela transformação do corpo humano vivo, em movimento, em corpo artístico, o cenário responde apresentando-se como lugar para, com a luz, elaborar as atmosferas nas quais o corpo vivo se manifestará. Um telão pintado torna-se, portanto, obsoleto.

O cenário ganhava nova abordagem para se tornar o "terreno" do ator, como explica Appia (1962, p. 64, tradução nossa):

\footnotetext{
132 "[...] la couleur, pour s'exterioriser et ne plus dependre des toiles verticales, [...]."

133 Da tradução inglesa: "[...] each of these objects is given a suitable color, and finally, light is used only to make them more or less visible".

134 "The illusion created by a work of art is not to delude us regarding the nature of emotions or objects in their relationship to reality, but rather to draw us so completely into the artist's vision that it seems to be our own."
} 
O terreno do ator no drama poético-musical é determinado, acima de todas as outras considerações, pela sua presença. Entenda-se que terreno não se refere apenas àquela parte do palco tocada pelos pés do ator, mas tudo na composição do cenário, relativo à forma material da personagem e às suas ações. ${ }^{135}$

Isso sugeria caminhos para decisões visuais que promoveriam harmonia na cena, exigindo alto grau de planejamento dos elementos cenográficos, inclusive da cor que, interagindo com a luz, expressaria as atmosferas indicadas, ou resultantes da ação. Uma vez que o terreno estaria desatrelado da ilusão figurativa, ele poderia ser concebido e construído com o objetivo de revelar profundas instâncias visuais evocadas pela ação das personagens. (APPIA, 1992) O afastamento da ilusão cromática aponta a nova função da luz:

Privada pela luz viva da sua própria vida no palco, a cor [pintada] perde os benefícios derivados da imobilidade na pintura. Se a cor deve funcionar como um elemento valioso na montagem, ela deve estar subordinada à luz. Pois, quando a luz deixa de ser fictícia, ela destrói a importância relativa de combinações de cores [da pintura de cenários]. A mobilidade característica de qualquer imagem da cena requer, portanto, que a iluminação assuma a maioria das funções anteriormente oferecidas pela cor, ao pintor. [...] As cores estáticas da pintura deixam de representar a luz, mas a luz retira da cor tudo aquilo que se opõe à sua mobilidade. ${ }^{136}$ (APPIA, 1962, p. 81, tradução nossa)

Appia (1962) propõe uma práxis cênica na qual a cor ganha nova posição e a luz nova função. A última deve ser concebida e planejada para, interagindo com os elementos do dispositivo cenográfico, revelar novas cores a cada cena, de acordo com as atmosferas criadas pela música. Além da capacidade de transmitir, de criar cor, Appia via, na cena, possibilidades técnico-estéticas da luz citadas em dois parágrafos que, pela sua importância, impõem menção integral:

135 "The terrain of the actor in the word-tone drama is determined above all other considerations by the actor's presence. Here it is to be understood that by terrain I mean not merely that portion of the stage trod by the actor's feet, but everything in the composition of the setting relating to the material form of the character and his actions." 136 "Color, deprived of its own life on the stage by living light, loses the benefits it once derived from immobility. If color is to perform as a valuable element in production, it must be subordinate to light. For when light ceases to be fictive in character, it destroys the relative importance of color combinations. The mobility characteristic of any stage picture requires, therefore, that the lighting assume a good many of the functions which color alone once gave to the painter. [...] It is no longer static colors which represent light, but light which takes from color all that opposes its mobility." 
A luz pode também projetar imagens que vão desde a gradação de tons mais delicados até os mais definidos efeitos. Um obturador [qualquer acessório para bloquear a luz], colocado diante da fonte de luz, pode dirigir um facho para uma parte do palco, deixando as outras áreas na escuridão. Começando com esse efeito simples, temos uma série de possibilidades, cujo escopo é limitado apenas pelas variedades, formas e combinações de transparências. A luz, que já ganha mobilidade pela presença dos atores, em cuja atividade ela toma parte, torna-se ainda mais móvel, se a fonte de luz pode ser movimentada, se as imagens projetadas são colocadas em movimento diante de uma fonte de luz estável, ou se a lente colocada na frente da fonte de luz pode, de alguma maneira, vibrar. Essas cores, formas e movimentos, combinadas entre si e com a imagem palco, oferecem inúmeras possibilidades; elas constituem a paleta do autor do drama poético-musical. ${ }^{137}$ (APPIA, 1962, p. 82, tradução nossa)

Ele compreendia a práxis cênica como uma manifestação artística que, já no drama, se impõe como uma assertiva visual:

Tanto a luz viva quanto a difusa requerem um objeto no qual sejam projetadas. A luz não muda a forma desses objetos, mas, ao contrário, serve para revelar sua presença e, portanto, torná-los expressivos. Com a adição de cor, a iluminação agora começa a modificar o esquema cromático do próprio objeto; além disso, uma fonte de luz equipada para projetar uma combinação de cores, ou uma imagem ou design, tem o poder de criar um ambiente no palco, e até mesmo de criar objetos através da projeção. Para tornarem-se visíveis as imagens projetadas devem atingir um objeto, o que vale tanto para a luz ordinária [sem cor] quanto para a colorida. Mas, ao contrário dos raios de luz simples, imagens projetadas afetam fortemente a natureza essencial desses objetos (para o espectador). Outrossim, esses objetos, por causa das suas várias formas e dimensões, respondem ativamente, modificando a imagem projetada. Portanto, se a inte-

\footnotetext{
137 "Light can also project images ranging from the most delicate gradation of hues to the sharpest effects. A shutter, placed over the source of light, can direct a beam to one part of the stage, leaving the other areas in darkness. Starting with this simple effect, we have a host of possibilities whose scope is limited only by the varieties, shapes, and combinations of transparencies used. The lighting, already made mobile by the presence of the actors, in whose activity it takes part, becomes even more so, if the light source can be moved about, if the projected images are placed in motion before a stable light source, or if the lens in front of the light source is vibrated in some manner. These colors, forms, and motions, variously combined with each other, and, in turn, with the stage picture, offer innumerable possibilities; they constitute the palette of the word-tone poet."
} 
ração entre a luz colorida e um cenário pintado é simplesmente uma questão de dimensões cromáticas, o problema da projeção está, além disso, associado às formas. Em ambos os casos, estamos preocupados com a cor dos objetos, independentemente dos efeitos de luz. Essa independência é, naturalmente, relativamente pequena, quando consideramos a soma total dos elementos que compõem a imagem cênica. ${ }^{138}$ (APPIA, 1962, p. 82, tradução nossa)

Confirma-se que, dispensando a pintura de telões, o teatro se concentraria numa nova categoria de arranjo espacial na qual a ilusão figurativa perdia seu papel dominante na qualidade plástica da cena. Tornava-se necessário procurar outros critérios através de meios plásticos para mensurar o grau de realidade do qual a cena deveria ser impregnada, já que o drama poético-musical apresentava proporções que não podiam ser encontradas no cotidiano, nos objetos com os quais o espectador estava familiarizado. O corpo do ator afirmava-se como parâmetro para a ligação com a realidade. Um corpo que desenvolveu grande capacidade vocal e domínio expressivo do movimento, através daquilo que Appia chama de treinamento em ginástica, ganhando em flexibilidade, no seu sentido mais amplo. Para serem levados à cena, os detalhes visuais da experiência cotidiana submeter-se-iam a uma seleção que até os poderia omitir inteiramente, de acordo com a representação visual de cada espetáculo. Alcançando a excelência da combinação entre luz e movimento, os elementos cênicos poderiam ser esteticamente concebidos em forma, cor e textura.

O interesse pelo realismo (figurativo) da cena dava lugar à expressão visual do drama poético-musical como espaço "verdadeiro". Até mesmo o ator podia ter sua própria dimensão/proporção reconsiderada para acentuar a expressão dos elementos inanimados, exigida por uma montagem. Afinal, quebravam-se os compromissos com qualquer imitação de realidade. Os novos princípios cêni-

\footnotetext{
138 "Both the living and the diffused light require an object on which to focus. The lighting does not change the form of these objects, but rather serves to make their presence felt, and hence to make them expressive. With the addition of color, the lighting now begins to modify the object's own chromatic scheme; moreover, a light source equipped to project a combination of colors, or an image or design, has the power to create an environment on stage, and even to create objects by means of projection. In order to be visible, projected images must strike an object as is the case for both ordinary and colored light. But, unlike simple light rays, projected images strongly affect the essential nature of these objects (for the spectator). Moreover, these objects, because of their various shapes and dimensions, respond by actively modifying the projected image. Therefore, if the interplay of colored light and painted scenery is simply a matter of chromatic dimensions, the problem of projection is in addition associated with forms. In both cases, we are concerned with the color of objects independent of the effects of lighting. This independence is, of course, relatively small when we consider the sum total of the elements making up the stage picture; yet its existence cannot be ignored any more than that of any other element of production."
} 
cos baseavam-se numa composição construída para cada cenário dado, no qual superfícies "poliformais" seriam distribuídas na cena. O que antes era pintura de telões, transformar-se-ia em "cor no espaço". A cor assume, portanto, o papel de simplificador "harmonizante": "A cor dos objetos, que constitui o estrito papel da pintura no nosso novo conceito de montagem, é importante para a forma do ator, em geral, e, particularmente, para a forma do seu figurino". ${ }^{139}$ (APPIA, 1962, p. 86, tradução nossa)

Ficava determinada a importância do modo como o ator seria iluminado, descartando-se o tratamento decorativo dos cenários que negariam sua presença viva, tornando-o apenas visível, a despeito dos inúmeros efeitos (meramente decorativos, que as novas combinações da luz possam oferecer). O tratamento visual do ator devia levar em consideração o figurino que transformaria seu corpo numa unidade visual particular, em cada espetáculo, cena ou momento. Nas palavras de Appia (1962, p. 89, grifo e tradução nossos): “[...] o figurino deve ser considerado, também, do ponto de vista da cor e do design". ${ }^{40}$ Essa relação entre cor e design indicava a relevância do projeto visual de cada montagem, que deveria interagir com os elementos vivos do espetáculo, a luz e o ator.

A compreensão de Appia (1962, p. 81, tradução nossa) é projetada firmemente, quando ele estabelece: "O autor do drama poético-musical pinta sua imagem com luz". ${ }^{141}$ A cena, portanto, seria imagem tridimensional pintada com luz, já presente no texto dramático e, no caso particular, desde a música. Essa é a primeira referência explícita à cena como uma imagem - ou sucessão de imagens - pintada(s) com luz. Tal princípio ainda carece de discussão no ambiente teatral brasileiro.

Qualquer relação de tais pressupostos com a cena que se efetivou ao longo das décadas que se sucederam, não será mera coincidência. Muito ao contrário, Appia comprovou que as revoluções propostas por sucessivas vanguardas teatrais, e até "antiteatrais", derivam da qualidade visual do espetáculo.

\section{Tristão e Isolda: entre Appia e Wagner}

Serão aqui consideradas relações estabelecidas por Appia com possíveis montagens da obra de Richard Wagner, concentrando as observações nas proposições referentes à ópera Tristão e Isolda (Tristan und Isolde) de Richard Wagner (música e libreto

\footnotetext{
139 "The color of objects, which constitutes the restricted role of painting in our new concept of production, is important for the form of the actor in general, and particularly for his costume."

140 "the costume must also be considered from the point of view of color and design."

141 "The word-tone poet paints his picture with light."
} 
escritos entre 1857-1859), levada ao público pela primeira vez em 1865 sob a condução do maestro Hans Guido Freiherr von Bülow (1830-1894). O libreto, escrito em alemão, apresenta uma livre versão do romance considerado obra-prima medieval germânica, Tristan, de Gottfried von Strassburg (?-1210) que se baseou, por sua vez, em uma lenda de origem celta que narra a história de dois jovens nobres Tristão e Isolda.

Esta abordagem específica da obra de Wagner leva em conta sua representatividade na história da música e da cena, o que recomenda alguma atenção para seu trabalho prático-teórico. Tal produção artístico-intelectual oferece pontos de interesse para a pesquisa nas artes cênicas incluindo obras que apresentam seus pressupostos para a nova arte da cena, de grande relevância para os estudiosos do teatro, se for considerada a influência da tragédia grega nas suas convicções em direção àquilo que ele chamou de Obra de arte do futuro, (Das kunstwerk der zukunft, 1849). Outros textos, como os longos ensaios Arte e revolução (Die kunst und die revolution), publicados no mesmo ano, além de Ópera e drama (Oper und drama, 1851), mostram a tentativa de sistematizar uma teoria que revelava ligações com o pensamento do filósofo alemão Arthur Schopenhauer (1788-1860).

Buscando novas rotas, Wagner vislumbrava uma obra de arte que incorporaria as qualidades de Shakespeare e Beethoven, resultando numa profunda força emocional, com a música assumindo grande papel descritivo - até criticado em Beethoven - e desempenhando funções semelhantes ao coro trágico grego. Sua elaboração do leitmotiv ${ }^{142}$ de relevante contribuição na estrutura narrativo-emocional da sua música pode exercer função qualificada na educação de designers, diretores e coreógrafos. Cabe citar, também, sua desaprovação da arte teatral do seu tempo que, em sua opinião, havia se transformado em mero entretenimento.

Não se pode ignorar críticas que consideram inconsistentes tanto os seus textos teóricos quanto os políticos, além da controvérsia que dá conta de uma influência de Wagner na trajetória de Adolf Hitler, acirrada pelas notas autobiográficas de Gottfried Wagner, bisneto do compositor, Wer nicht mit dem wolf heult, obra da qual não foi identificada tradução em português e que, em inglês, aparece como He who does not howl with the wolf (Aquele que não uiva com o lobo), publicada em 1997.

O trabalho em curso acentua a relação estabelecida por Appia com o drama poético-musical de Wagner e, particularmente, com sua ópera Tristão e Isolda. Dividido em três atos, o libreto da obra inicia com eventos que ocorrem durante uma viagem de Tristão, que segue da Irlanda para a Cornuália, na Inglaterra. 
Seguindo ordens do rei Marke, seu tio, ele transporta em seu navio a jovem Isolda, noiva prometida ao rei. Num diálogo entre Isolda e sua confidente Brangânia (Brangäne), toma-se conhecimento que a jovem já conhecia Tristão antes dessa viagem: depois da morte do seu noivo Morold numa recente batalha, ela encontrou um desconhecido mortalmente atingido na mesma contenda, e usou seus poderes de cura, ou antigos conhecimentos farmacêuticos, para recuperá-lo.

Durante o restabelecimento do enfermo ela descobre que, na verdade, o homem é o assassino do seu noivo e decide matá-lo. Despertando, ao invés de dar atenção à espada ou à mão que lhe ameaça a vida, Tristão fita diretamente os olhos de Isolda. Diante dessa atitude ela decide libertá-lo exigindo que ele jamais retorne à Irlanda. Apesar disso, fiel ao rei ele volta, obedecendo ordens de levá-la à Cornuália. Sentindo-se ultrajada, Isolda decide vingar-se e solicita a presença de Tristão à sua tenda com o pretexto de celebrar uma espécie de ritual de perdão compartilhando uma bebida. Na verdade, ela instrui a criada para que essa thes sirva um veneno, ou poção da morte. Relutante, Tristão comparece ao encontro e, mesmo temendo morrer, bebe a poção, acompanhado pela "noiva" do rei. A reviravolta nas pretensões de Isolda ocorre quando, depois de ingerir a bebida, os dois se revelam profundamente apaixonados: Brangânia, a criada confidente, confessa que trocou o conteúdo do vaso por uma poção do amor. O primeiro ato é concluído com o final da viagem e a subida a bordo do rei Marke, da Cornuália.

Além de introduzir a narrativa, esse momento apresentava um traço valioso para a argumentação em curso: ameaçado de morte, um homem ganha a liberdade através da simples ação de olhar nos olhos do seu iminente algoz. O mito abre portas para as convicções cênicas de Appia. Ele considerou que a cabine-tenda poderia representar uma espécie de cárcere, mas provê certo conforto a Isolda: com as cortinas fechadas e a cabeça embaixo de almofadas ela se afasta da luz do dia cujo brilho acentua sua dor através da visão que expõe e confirma a traição de Tristão. A voz do marinheiro, que abre o ato, impõe a realidade para a qual ela não encontra outra saída senão enfrentar a luz. Registrando a presença de Tristão e diante da impossibilidade de escapar, ela se nega a mergulhar na passividade. Retornando à tenda, sob a proteção (visual) das cortinas que deixam lá fora a realidade iluminada e exposta pela luz, ela prepara a vingança. Appia (1962, p. 206, tradução nossa) apresenta uma interpretação visual da ação:

As cortinas da tenda de Isolda, por conseguinte, separam simbolicamente, no sentido mais pleno do termo, o aspecto visual do mundo exterior da expressão da vida interior. O conflito que constitui a ação dramática é então realizado diretamente dian- 
te dos nossos olhos em uma forma plástica justificada pela expressão dramática, e completa, desde as necessidades básicas do lugar até as demandas mais sutis do som. ${ }^{143}$

Exemplificando a natureza do pensamento visual presente na cena, Appia deixou pistas para a incorporação de excelência a uma montagem de Tristão e Isolda através da elaboração do contraste entre os dois ambientes. No interior da tenda da heroína encontra-se a expressão da face interior do conflito e as cortinas atuam como pálpebras que se abrem para revelar a realidade externa. Na elaboração das imagens cênicas, o iluminador pode avaliar a provocação dessa contundente imagem-metáfora.

Appia (1962) considerava que a luz no interior da tenda deveria ser difusa e uniforme. A intensidade seria reduzida a ponto de fornecer iluminação suficiente para que fosse visto o rosto do ator e estabelecer contrastes com o exterior brilhantemente iluminado. Appia indicou uma sugestão de tempo (hora) através dos ângulos e cores da luz, desde o início do ato, quando ela deveria cair perpendicularmente sobre o ambiente, inclusive sobre a tenda, sem alcançar diretamente o seu interior. Adiante, quando a ação se passa ao cair da tarde, Appia (1962, p. 206, tradução nossa) propôs: "[...] a luz no exterior é menos brilhante, mas os raios são mais inclinados; eles cobrem a parte 'baixa' do palco, como um grande e brilhante tecido dourado". 144

Se o primeiro ato poderia ser intitulado "a poção do amor" (ou da morte), a ação principal do segundo está no momento em que Tristão é mortalmente ferido. Esse segundo ato começa com o som de uma caçada ao longe. Acompanhado dos seus súditos, o rei Marke afasta-se do castelo para um entretenimento na noite de verão. Na companhia de Brangânia, defronte do jardim no qual apenas uma tocha ilumina o ambiente Isolda aguarda o momento propício quando o som das cornetas ao longe anunciará o afastamento seguro dos homens, permitindo-lhe enviar ao seu amado um sinal para o almejado encontro. Na espreita, ele espera que Isolda apague a tocha. A primeira cena encerra-se quando os dois se aproximam do lugar combinado, protegidos pela noite e pela escuridão.

\footnotetext{
143 "The curtains of Isolde's tent thus symbolically separate in the fullest meaning of the term the visual aspect of the outer world from the expression of inner life. The conflict which constitutes the dramatic action is then directly realized before our eyes in a plastic form justified by the dramatic expression, and complete, from the bare necessities of place to the most subtle demands of sound."

144 "[...] light is less bright (it is late afternoon), but the rays are more slanted; it covers the floor of the downstage area as with a large bright golden cloth."
} 
A cena seguinte mostra o repúdio de ambos ao dia que traz a luz capaz de expor seus desejos. As trevas da noite são tratadas como "doce escuridão" que abriga os amantes. Isolda anuncia que o dia traz a morte. Pulsa no encontro dos enamorados a ameaça do nascer do sol, que tem o poder de expor seu inevitável amor proibido. Apesar dos avisos de Brangânia, eles não conseguem se separar e concluem a cena num abraço arrebatador. A última parte do segundo ato inicia-se com o retorno do rei com seu séquito, guiados por Melot - um dos cavaleiros da corte - também apaixonado por Isolda. Tristão desafia Melot que ergue sua arma ao tempo em que o herói se desfaz da sua própria espada e recebe um duro golpe que lhe será fatal.

A interpretação de Appia (1962) demonstra como a luz pode se constituir na linha mestra da obra. Ele descreve o início de segundo ato que gostaria de ver:

A aparência do palco, quando a cortina se abre: uma tocha grande e brilhante no centro da imagem. O espaço bastante limitado do palco é iluminado por uma luz difusa, suficiente para fazer as personagens claramente distintas, sem privar totalmente a tocha de seu brilho, um tanto ofuscante [.... ${ }^{145}$ (APPIA, 1962, p. 200, tradução nossa)

Antes, ele já havia ponderado que, ao entrar em cena Isolda vê apenas a tocha, registra a ausência de Tristão, e toma uma decisiva atitude para a ação dramática: "Extinguindo a luz da tocha Isolda remove os obstáculos, [...]". ${ }^{146}$ (APPIA, 1962, p. 199, tradução nossa) Ainda que a visão da realidade material para os amantes, assim como para nós espectadores, permanecerá muito limitada até que a luz do dia invada ameaçadoramente o ambiente, o que deve ser visto em cena, segundo Appia, é apenas a presença de ambos, assim fisicalizada:

Aparece para nós, assim como para eles, aquilo que arde nos seus corações, superior às suas formas visíveis, e a existência fictícia da música nos transporta, cada vez mais profundamente, para o interior do misterioso mundo no qual sua união se consumará para sempre. ${ }^{147}$ (APPIA, 1962, p. 200, tradução nossa)

O ambiente da cena está envolvido numa densa penumbra que os transforma em espectros, diluindo visualmente as formas da arquitetura e da natureza,

\footnotetext{
145 "The appearance of the stage when the curtain opens: a large bright torch in the center of the picture. The rather limited space of the stage is illuminated by a diffuse light, just enough to make the characters clearly distinguishable without entirely depriving the torch of its somewhat blinding brightness, nor above all, destroying the shadows projected by this brightness."

146 "By extinguishing the torch Isolde removes the obstacle, [...]."

147 "What burns in their hearts appears to us, as to them, superior to their visible forms, and the fictitious existence of the music carries us deeper and deeper into the mysterious world where their union is consummated forever."
} 
confundindo o olhar do espectador que, somente aos poucos, se adapta à atmosfera. Ainda assim, a apreensão visual das personagens deve ser sempre vaga, um tanto indefinida. Anunciando a chegada do rei o dia brilha, como o próprio Appia diz, sem cor. Aqui parece que ele está dispensando qualquer sugestão cromática do nascer do sol e indicando um tratamento frio para a luz, sem a aplicação de matizes comuns a esse momento numa abordagem realista. O sol entra como uma afiada arma branca que corta a densa penumbra abrindo espaços para revelar as personagens e o ambiente, de modo claro e direto. Para Tristão, desafortunadamente, o retorno à claridade abre as portas do infortúnio, ao final do segundo ato.

$\mathrm{O}$ ato seguinte e conclusivo encaminha como desfecho as mortes de Tristão e Isolda. O honrado cavaleiro do primeiro ato e dedicado amante do segundo é agora somente um homem mortalmente ferido. Ele foi levado inconsciente pelo seu escudeiro Kurvenal para o castelo abandonado dos seus ancestrais. No jardim diante do castelo, Tristão aparece adormecido num sofá colocado à sombra de uma limeira, observado por Kurvenal. O escudeiro mandou chamar Isolda assegurando que somente sua presença fará Tristão sobreviver. Eles esperam uma canção alegre que será tocada por um pastor para anunciar a chegada de Isolda.

Tristão desperta e desejando na música o anúncio jubiloso pensa, ao invés disso, ouvir a mesma canção tocada, no passado, quando the foi revelada a morte dos seus pais. Exausto, delira. Ouve-se a flauta do pastor que traz a boa notícia. Kurvenal apressa-se para encontrar Isolda. Agitado, Tristão retira os curativos das suas feridas. Na chegada de Isolda ele morre proferindo o nome da amada. Appia observa essa precipitação de breves acontecimentos através da relação com a luz. Ele comenta as atitudes de Tristão: "[...] ele pensa somente na sensação de luz, que causa distúrbio e dor, e na sensação de escuridão que lhe escapa, mas que ele gostaria de recuperar"148 (APPIA, 1962, p. 203, tradução nossa)

Na opinião de Appia, a luz do sol, no início do terceiro ato, tem a mesma função da tocha usada no início do ato anterior, que afasta os amantes. O sentido da visão ganha qualidade simbólica na alucinação de Tristão, que "vê" em sua imaginação ou delírio (sem a necessidade da luz física do sol que afastaria qualquer alívio, ampliando o sabor amargo da sua aflição) o navio que traz a amada. A melodia tocada pelo pastor projeta revelações. Tristão, no entanto, desfalece, mergulhando na segurança do sono ou, da escuridão "noturna".

A mágica visão da amada tornar-se-á realidade sob a luz física do sol. Para Tristão, no entanto, ela deve apagar-se transformando a escuridão em abrigo.

148 "he can think only of a sensation of light that disturbs and pains him and of a sensation of darkness escaping him but which he would like to retrieve." 
Diante de Isolda, portanto, ele morre em seus braços. Appia (1962, p. 204, tradução nossa) descreve o momento:

A bela claridade da luz do dia - que se tornou a sua ilusão suprema - lentamente desaparece no horizonte marinho lançando um último halo tingido de sangue em torno dos amantes que se reencontram. | Assim, o papel desempenhado pela luz é claramente prescrito para o ato. Como a luz é apenas uma fonte do sofrimento de Tristão ela não deve cair diretamente sobre ele. Mas, assim que ele realmente a associa a visões de felicidade, ela o alcança e ilumina seu rosto. ${ }^{149}$

Aqui se pode observar um procedimento ou um método que caracterizaria as funções da visualidade na práxis cênica. A abordagem do iluminador, mesmo organicamente ligada aos pressupostos da dramaturgia e da direção, apresenta contribuição particular, pois apenas a luz pode representar tal papel. Os contrastes evidenciados nas cores, texturas, formas, intensidades, a composição de cada imagem cênica, enfim, determinaria a presença da luz no espetáculo que, efêmera, desempenharia funções exclusivas.

Aqui se encontra um dos mais importantes aspectos das relações entre a luz e a cena. Comprometida esteticamente, ela dispensaria sua própria acentuação indiscriminada e promoveria a construção das imagens cênicas, de um modo que somente o olhar particularmente educado seria capaz de observá-la tecnicamente e avaliar sua contribuição.

Appia faz proposições para a cena que podem exemplificar suas expectativas de elaboração das imagens:

Na página $215,{ }^{150}$ tornando-se cada vez mais dourada, a luz começa a tocar os pés de Tristão, na página 218 chega até a cintura; na página 221, ela toca o seu rosto; na página 223, Tristão está totalmente iluminado; na página 225 , o facho se estende a seus arredores. ${ }^{151}$ (APPIA, 1962, p. 205, tradução nossa)

\footnotetext{
149 "The beautiful clarity of daylight - which became their supreme illusion - slowly sinks below the sea's horizon throwing a last bloodtinged halo around the reunited lovers. | So the part played by lighting is clearly prescribed for the act. As long as light is only a source of Tristan's suffering, it must not fall on him directly. But as soon as he really sees it and associates it with blissful visions, it comes and illuminates his face."

150 Essa numeração de páginas refere-se à partitura vocal, preparada por Hans von Buelow, e publicada por Breitkopf \& Haertel, em Leipzig, e também em Nova lorque.

151 "On page 215, the light, turning increasingly more golden, begins to touch Tristan's feet; on page 218 it reaches up to his waist; on page 221 it touches his face; on page 223 Tristan is fully lighted; on page 225 , the beam extends to his surroundings."
} 
O que poderia ser um pôr do sol fixado numa composição pintada, torna-se um movimento que constitui uma assertiva visual em profunda cumplicidade com a ação cênica, com o tempo inscrito pela música, inundando o espaço cênico da atmosfera romântica da qual estaria impregnado o espetáculo. No tratamento em questão pode-se observar porque a abordagem de Appia se rebelava contra a pintura de telões cujo congelamento da luz lhe parecia desconectado da qualidade viva da cena. Ele já diagnosticara essa impropriedade: "Os arranjos de cores, bem como as formas que expressam a sua qualidade e variações de luz e sombra, não só perdem a sua expressividade na presença dos elementos vivos, mas também o seu significado". ${ }^{152}$ (APPIA, 1962, p. 78, tradução nossa)

\section{Sombras reveladoras}

Ainda que as combinações de forma, cor e movimento mencionadas por Appia tenham influenciado enormemente a prática da iluminação teatral que lhe sucedeu, ele incluiu nessa última assertiva outro aspecto da cena a respeito do qual não se observa grande interesse da prática da iluminação para o palco, tampouco da teoria que trata da cena. Quando ele diz "variações de luz e sombra", se for considerada a importância da sombra na sua obra, ficam sugeridas pesquisas específicas acerca do tema.

Mesmo que seu trabalho trate de relações entre o arranjo espacial e a luz ele faz menções à sombra que podem intrigar o leitor. Numa primeira instância, referindo-se à potencialidade da luz para envolver a cena em atmosferas, ele faz sua primeira inserção objetiva da sombra no universo da cena: "[...] [se] o espectador deve apreender a existência real de uma janela, um edifício, um pórtico, uma rocha, o limite de uma floresta, o mastro de um navio etc., a luz pode apresentar esses objetos através do uso da sombra". ${ }^{153}$ (APPIA, 1962, p. 67, tradução nossa) Appia não estava discutindo o chamado "teatro de sombras", mas indicando a imperativa necessidade da sombra para a fisicalização do corpo em cena, da imagem cênica. Essa operação técnica, que ganha qualidade estética no corpo de um espetáculo, origina-se na observação da luz natural, como ele expõe:

\footnotetext{
152 "The color arrangements, as well as the forms they express through their quality and variations of light and shade, lose not only their expressiveness in the presence of the living elements, but also their meaning."

153 " $[. .$.$] the spectator must apprehend the actual existence of a window, a building or portico, a rock, the edge of$ a forest, ship's mast, etc., the lighting can present these objects by means of shadows."
} 
A luz do dia inunda toda a atmosfera, mas, mesmo assim, estamos sempre conscientes da direção de onde ela vem. Mas a direção da luz só pode ser detectada através da sombra - é a qualidade das sombras que exprime a qualidade da luz. As sombras são formadas pela mesma luz que ilumina a atmosfera. Esse enorme efeito não pode ser obtido artificialmente. O brilho de uma fogueira acesa em uma área escura nunca irá produzir luz suficiente para criar o que chamamos de claro-escuro, isto é, a sombra mais ou menos distinta que se projeta sobre uma área já iluminada. No palco, essa tarefa deve ser dividida de modo que parte do equipamento de iluminação seja aplicada para a iluminação geral, enquanto o restante cria as sombras por meio de fachos exatamente dirigidos. ${ }^{154}$ (APPIA, 1962, p. 74, tradução nossa)

Na condiçao de responsável pela criação das imagens cênicas, o iluminador pode avaliar a indicação de Appia quando ele considera a observação sistemática da luz - incluindo a luz natural - como procedimento relevante para o seu traba1ho. Leve-se em conta que Appia estava tratando de um teatro no qual a ilusão realista devia ser banida e, ainda assim, ele considerava que o processo investigativo da luz deve ser abrangente. Suas breves observações acerca da sombra deixaram pistas da importância do mencionado processo para a cena ou, antes, para a apreensão humana do mundo:

[...] não há objeto plástico de nenhum tipo, animado ou não, que possa dispensar a sombra. Se não há sombra, não há luz; pois luz não é simples 'visibilidade' [...] apenas a plateia está interessada em 'visibilidade' - a luz distingue-se da visibilidade pela virtude do seu poder de ser expressiva. ${ }^{155}$ (APPIA, 1962, p. 75, tradução nossa)

Em primeiro lugar, até mesmo uma apreensão primária humana do mundo visível depende da presença da sombra, desde aquela produzida pela luz natural até as diversas possibilidades de sombras decorrentes das fontes artificiais de luz.

154 "Daylight floods the whole atmosphere, but nevertheless we are always aware of the direction from which it comes. But the direction of light can only be sensed by means of shadow - it is the quality of the shadows which expresses the quality of light. Shadows are formed by the same light which illuminates the atmosphere. This tremendous effect cannot be obtained artificially. The brightness of a lighted fire in a dark area will never produce sufficient light to create what we call chiaroscuro, i.e., the more or less distinct shadow cast on an already lighted area. On stage this task must therefore be divided, so that part of the lighting equipment will be used for general illumination, while the rest will cast shadows by means of exactly focused beams."

155 " [...] there is no plastic object of any kind, animate or otherwise, which can dispense with shadow. If there is no shade, there is no light; for light is not simple 'visibility' [...] only the audience is concerned with 'visibility' - light is distinguished from visibility by virtue of its power to be expressive." 
No desejo de substituir o sol, com o intuito de ampliar ou prolongar sua relação de visibilidade com a vida até para ampliar seu tempo produtivo, o ser humano inventou a luz artificial e gerou um novo mundo de sombras. Na obra de arte em geral - na práxis cênica, em particular - essas sombras emprestam poder expressivo à luz, promovendo a diferença entre visibilidade e aquilo que denominei visualidade, alcançada pela inclusão estética da sombra, em um projeto de luz. Isso exige do iluminador familiaridade com os instrumentos e acessórios, para determinar a distância entre a fonte de luz e o objeto a ser revelado expressivamente, os ângulos, as formas e texturas com as quais se pode definir a qualidade da sombra.

É provável que o conhecimento da geometria aliado à familiaridade com os materiais oferecidos pelo dramaturgo e suas ramificações possa contribuir, tanto nos cálculos necessários para as definições técnicas, quanto na qualificação estética do trabalho do iluminador. No teatro proposto por Appia, melhor que "iluminador" talvez a denominação indicada fosse "sombreador", se o artista compreende a expressividade visual, a qualidade estética da sua contribuição, como um processo que desconstrói as fronteiras da visibilidade e instala a visualidade através da criação de sombras. Sombras que alcançam um estágio diferente daquele fixado na pintura de telões, pois, de acordo com Appia (1962, p. 75, tradução nossa), as sombras pintadas corrompem a cena com falsas imagens: "[...] o cenário pintado pode tornar-se expressivo somente na ausência do ator, pois a imitação de luz pintada no telão corresponde, igualmente, às falsas sombras pintadas". ${ }^{156}$ Ele procurou, ainda, esboçar um método para a aproximação técnica da sua proposição estética.

Evitar as sombras causa interferência na energia da luz viva; [...] por meio da luz difusa atingimos a 'visibilidade' no palco; as sombras serão neutralizadas e prontas para a luz viva. Com a exceção de alguns casos bastante raros nos quais uma das duas formas de luz deve operar de modo independente, não é preciso dizer que temos de começar com 'visibilidade'. A intensidade da luz difusa, em seguida, será modificada pela luz viva. ${ }^{157}$ (APPIA, 1962, p. 77, tradução nossa)

\footnotetext{
156 "the painted setting can become expressive only in the absence of the actor, because the imitation light painted on the canvas corresponds to the equally false painted shadows."

157 "To avoid the shadows would interfere with the power of living light; [...] by means of the diffused light, we achieve 'visibility' on the stage; the shadows will be neutralized and ready now for the living light. With the exception of some rather rare instances in which one of the two light forms must operate independently, it goes without saying that we must begin with 'visibility'. The intensity of the diffused light will then be modified by the living light."
} 
Appia parecia dizer que essa pintura com luz proposta para o drama poético-musical, exigia a elaboração de uma base ou suporte, aplicando a luz difusa para eliminar sombras desnecessárias à expressividade do espetáculo, para depois serem elaboradas as sombras exigidas em cada cena ou momento. No sentido positivo do termo, trata-se de criar sombras artificialmente planejadas pelo "sombreador" (já que a tarefa do "iluminador" ficou concluída no estabelecimento da luz difusa, de preenchimento, generalizante, e até colorida). Ele justificou: "[...] que modo de existência poderíamos imaginar para a luz, além da oposição de intensidades ocasionadas pelas sombras - e como é possível imaginar sombras, senão em termos dos objetos que as originam?". 158 (APPIA, 1962, p. 77, tradução nossa)

Fica evidenciada uma profunda relação com a organização dos elementos visuais da cena, incluindo o ator, tratado como um aspecto visual. Por outro lado, as implicações emocionais, humanas e sociais da personagem exigem um tratamento visual particularizado, de acordo com suas funções em cada espetáculo. Portanto, para observar o ator como corpo e elemento visual da cena, exige-se do "sombreador" familiaridade - para não usar o termo domínio - com as diversificadas instâncias técnico-estéticas que permeiam, circundam e perpassam a cena. Sua função inclui, segundo Appia (1962, p. 78, tradução nossa): “[...] promover os meios para a projeção das sombras, permitindo, assim, que a luz viva trabalhe”. ${ }^{159}$

Ele propôs exemplos práticos que podem corroborar sua compreensão das sombras como elementos essenciais da cena. Já no primeiro ato de Tristão e Isolda, no qual a luz do sol deve expor a realidade, agredindo Isolda que dela decide se afastar, pode-se observar:

A iluminação dessa área será bastante uniforme, sem qualquer sombra. [...] permitindo que os planos característicos das faces sejam claramente vistos. Pelo contrário, a área ao ar livre será brilhantemente iluminada e sua realidade enfatizada através de uma variedade de sombras lançadas sobre a tenda. ${ }^{160}$ (APPIA, 1962, p. 207, tradução nossa)

Pode-se dizer que o papel da sombra na elaboração da imagem cênica estava aí delineado. Mesmo quando Appia chamou a atenção para a necessidade da

\footnotetext{
158 "But, what mode of existence could we imagine for light except the opposing intensities occasioned by shadows - and how is it possible to imagine shadows but in terms of the objects causing them?"

159 Da tradução inglesa: "[...] furnishing the means of casting shadows, thus enabling the living light to function." 160 "The illumination of this area will be quite uniform, with no shadow whatever. [...] will permit the characteristic planes of the faces to be distinctly seen. By contrast, the outdoor area will be brightly lighted and its reality emphasized through a variety of shadows thrown against the tent."
} 
eliminação das sombras no interior da tenda de Isolda, o que, por um lado, pode sugerir argumentos para aqueles que pretendam questionar o valor das sombras, por outro, a observação atenta pode fazer cair por terra certas contestações. Appia tentou explicitar que nesse momento as sombras projetadas pelos corpos devem ser evitadas, uma vez que não há nenhuma fonte de luz no interior da tenda e precisamente porque essa condição é imprescindível para a elaboração do pensamento visual, que suporta e exprime a relação de Isolda com a realidade exposta pela luz, pelo conhecimento que lhe sublinha a morte do noivo, seu infortúnio. Ou seja, a realidade é construída visualmente nas sombras duramente projetadas pela luz natural que incide sobre o exterior da tenda:

Brangânia ergue um canto da parede lateral para olhar para o mar, o espectador vê apenas uma parte ínfima do horizonte, percebendo o exterior somente através da luz brilhante que roça os pés da cantora, sem penetrar o suficiente para lançar uma sombra pesada sobre o chão da tenda. ${ }^{161}$ (APPIA, 1962, p. 207, tradução nossa)

A narrativa encaminhada durante todo o espetáculo vislumbrado por Appia (1962, p. 207, tradução nossa) inscreve-se visualmente:

Quando as cortinas da tenda são abertas pela primeira vez (páginas 13-14), a luz de fora, caindo quase em linha reta, não passa além do limiar da tenda. Na página 80, quando elas se abrem de novo, a luz exterior é menos brilhante (estamos no final da tarde), mas os raios estão mais inclinados; eles cobrem o piso da parte frontal da cena, como um grande e brilhante tecido dourado. As sombras das personagens caem em direção ao público. Tudo o que se vê são dois grupos de pessoas: aqueles que serão recebidos, e aqueles que os observam de frente, aguardando o rei. ${ }^{162}$

Deve-se atentar para a relevância de tais construções visuais, assim como para o decisivo papel das sombras no teatro de Appia (1962, p. 207, tradução nossa):

\footnotetext{
161 "Brangaene lifts a corner of the side wall to look at the sea, the spectator sees merely an infinitely small part of the horizon, perceiving the outdoors only through the bright light that grazes the singer's feet without penetrating enough to throw a heavy shadow on the tent floor."

162 "When the tent curtains part for the first time (page 13-14), the light from outside, falling almost straight down, does not pass beyond the threshold of the tent. On page 80 when they open again, the outside light is less bright (it is late afternoon), but the rays are more slanted; it covers the floor of the downstage area as with a large bright golden cloth. The shadows of the characters fall toward the audience. All that is seen is two groups of people: those who are to be received, and those who face them waiting for the king."
} 
Aquelas [personagens], no primeiro grupo (em especial, Tristão e Isolda) atingido por um raio oblíquo, que vem do fundo do palco, são vistas pelo público como silhuetas sombreadas, o segundo grupo não está colocado diretamente entre a luz [o instrumento, o 'refletor'] e o espectador sendo, então, muito mais brilhantemente iluminado e totalmente visível. ${ }^{163}$

A mencionada abordagem estende-se ao segundo ato, aparecendo desde a primeira imagem que denota nas proposições da cena um alto nível de atenção, não apenas para a luz, mas também para a sombra.

O espaço bastante limitado do palco é iluminado por uma luz difusa, suficiente para fazer as personagens claramente distintas, sem privar totalmente a tocha de seu brilho um tanto ofuscante, nem, acima de tudo, destruir as sombras projetadas por esse brilho. ${ }^{164}$ (APPIA, 1962, p. 200, tradução nossa)

Sem a pretensão de criar uma obra de arte isolada a cada imagem elaborada, ele acentuava a necessidade de tratá-la como um novo componente do discurso visual do espetáculo em questão. Levando-se em conta a harmonia buscada por Appia, a sucessão de imagens deveria constituir-se de elementos que estabeleceriam a unidade visual que construiria a totalidade da obra, indicando rigor na elaboração de cada movimento da luz, consequentemente, de cada imagem em movimento. Se ele acreditava que toda imagem necessita da sombra para se tornar presente a excelência do espetáculo dependia da precisão de cada sombra.

A sombra, portanto, que pode remeter a um simples buraco escuro, o preto, ausência, repetição negativa e vazia, tem aqui papel decisivo e muito diferente da sombra em Platão, que sugere ignorância e limitação, como na parábola da caverna, e mais próxima daquela sombra que aparece na obra de Caio Plínio, o Velho (23-79). Tratando da criação da escultura, ele constata:

Butades, um oleiro de Sicyon, inventou em Corinto a arte da modelagem de retratos na terra, que ele usou no seu comércio. Ele fez a descoberta através da sua filha, que, profundamente apaixonada por um jovem que estava prestes a partir para uma longa viagem, traçou o perfil do seu rosto, projetado sobre uma

163 "Those in the first group (in particular Tristan and Isolde), hit by a slanted ray from upstage, are seen by the audience as shadowed silhouettes; the second group is not placed directly between the spotlight and the spectator, and consequently is much more brightly lighted and fully visible."

164 "The rather limited space of the stage is illuminated by a diffuse light, just enough to make the characters clearly distinguishable without entirely depriving the torch of its somewhat blinding brightness, nor above all, destroying the shadows projected by this brightness." 
parede pela luz de uma lamparina. Ao ver isso, o pai da jovem preencheu o contorno, através de compressão de argila na superfície, e assim fez o rosto em relevo, que foi então endurecido pelo fogo, juntamente com outros artigos de cerâmica. ${ }^{165}$ (PLINY, 1867, p. 283, tradução nossa)

A sombra aqui recebe abordagem positiva, quando registra e preserva a forma da pessoa amada, criando uma presença que desconstrói a ausência iminente.

Na descrição de Appia, imprescindível para a compreensão expressa na presente abordagem, quando a cortina se abre, os artistas compartilham imagens com o espectador. Parece claro, ainda que nem sempre conscientemente assumido: seja a abertura da cortina ou outro instrumento de corte realidade-ficção efetivado no começo de um espetáculo, uma imagem é oferecida ao público. E se uma cortina neutra for mantida fechada e o espetáculo começar com estímulos sonoros, o espectador responderá com seu imaginário, elaborando associações, criando suas próprias imagens mentais. A simplicidade da imagem proposta por Appia determina certas exigências em Tristão e Isolda: o espaço da cena deve ser iluminado por uma luz difusa, sugerindo que a iluminação está sendo provida por uma tocha posicionada em um ponto específico da imagem cênica. Essa iluminação revela claramente as personagens, mas deve evidenciar o valor físico do brilho da tocha como fonte principal de luz.

E, finalmente, devem ser reveladas as sombras originadas pelas relações entre a tocha e os corpos que se oferecem como obstáculos. Essa operação exige conhecimento técnico para fazer interagir intensidade, contraste, cor, ângulo, textura e movimento, aproximando-se daquilo que a prática da luz para a cena no século XX denominou, nos EUA, luz "motivada". ${ }^{66}$ Vale chamar a atenção para a instabilidade da luz de uma tocha, que impregnaria a cena com uma qualidade muito particular de luz e sombra em movimento.

Parece óbvio que hoje em dia, além da tocha propriamente dita e dos instrumentos aplicados para a luz difusa, outros tantos podem ser usados para criar sombras, como se elas fossem efetivamente criadas por essa tocha. De todo modo, tal conceito de imagem se diferencia da compreensão atual da imagem gravada, editada, mani-

165 "Butades, a potter of Sicyon, was the first who invented, at Corinth, the art of modeling portraits in the earth which he used in his trade. It was through his daughter that he made the discovery; who, being deeply in love with a young man about to depart on a long journey, traced the profile of his face, as thrown upon the wall by the light of the lamp. Upon seeing this, her father filled in the outline, by compressing clay upon the surface, and so made a face in relief, which he then hardened by fire along with other articles of pottery."

166 Uma luz que parece originar-se numa fonte específica, como uma lâmpada, o sol, uma fogueira, entre outros. (BOULANGER; LOUNSBURY, 1992, p. 102) 
pulada eletronicamente e reproduzida. Appia tratou da imagem cênica, efêmera, elaborada imediata e sucessivamente diante do espectador, com precisão e maestria que promoveria interação e construiria as visões da obra em questão.

No decorrer do segundo ato de Tristão e Isolda, os heróis parecem mixados ao ambiente quando permanecem mergulhados na penumbra, numa visualidade que atua diretamente na qualidade da ação dramática ao camuflar os amantes.

Após descrever o ambiente do terceiro ato, Appia (1962, p. 204, tradução nossa) traça recomendações finais: "Apenas aquilo que é estritamente necessário para proteger as coxias e para motivar as sombras que preenchem o pátio deve ser adicionado a essa construção simples." ${ }^{167}$ Mais uma vez observa-se que a sombra se configurava como um aspecto essencial da sua abordagem espetacular. Isso pode incluir a extensão, a cor e a textura de cada sombra projetada na cena:

Durante as páginas 233-236, o palco atinge o máximo de luz, relativamente baixa, pois a parte da parede que limita a visão do céu, ao fundo do palco, lança uma profunda sombra sobre grande parte do pátio, principalmente sobre a porta, e áreas mais próximas. ${ }^{168}$ (APPIA, 1962, p. 205, tradução nossa)

Uma elaboração visual dessa natureza, que inclui uma sombra de tamanha extensão, pode lembrar outro aspecto decisivo da criação das imagens cênicas, ou seja, o preenchimento das sombras. Um evento que ocorre na natureza ou, na realidade objetiva, e que deve ser elaborado artificialmente na cena, estabelece um alto grau de dificuldade técnica, uma vez que, em certos espetáculos, certas cenas ou certos "momentos-imagem", as sombras não podem ser projetadas de modo simplório como um buraco negro inevitável ou acidental na cena. Ao contrário, pode haver a necessidade de inserir na sombra um grau de visibilidade ou realidade, somente alcançado com a aplicação de critérios técnico-estéticos muito específicos, por vezes relacionados a um raciocínio gráfico, visual, geométrico, físico, cujo resultado (ou forma) só raramente será encontrado no cotidiano fora do teatro.

Em algumas ocasiões, quando um espetáculo muda de teatro, numa excursão ou nova temporada, torna-se difícil para um ou outro envolvido no processo, compreender que determinada casa de espetáculos - algumas delas nem sequer qualificadas para receber a simples denominação de teatro - não apresenta condi-

167 "Only what is strictly needed to mask the flies and to motivate the shadows which fill the courtyard should be added to this simple construction."

168 During pages $233-236$, the stage attains the maximum of light which is relatively low, for the section of wall restricting the view of the sky upstage throws a deep shadow over a large part of the courtyard, especially over the door and its approaches". 
ção técnica para assegurar a criação das sombras que o espetáculo em questão exige. Parece difícil aceitar que a simples posição de uma vara de luz tenha participação efetiva na elaboração da visualidade de um espetáculo; e que a visualidade tenha tal importância; e que as sombras mereçam "tamanha" atenção. O que pensaria Appia em uma situação de tal natureza?

O exemplo a seguir, que ainda se refere ao terceiro ato de Tristão e Isolda, revela como um iluminador pode aplicar variações de sombra de modo muito especificamente relacionado a cada evento:

Começando na página 236, a iluminação assume os tons do pôr do sol, em seguida, rapidamente diminui sua intensidade durante as páginas 238-242, até que, nas páginas 245-248, a ação turbulenta ocorre em relativa escuridão e o público não pode distinguir seus detalhes, enquanto as áreas da frente do palco são atingidas diretamente por uma luz que se torna cada vez mais vermelha... ${ }^{169}$ (APPIA, 1962, p. 205, tradução nossa)

A recomendação final de Appia pode servir como alerta para o estudo da sombra, assim como de sua aplicação na práxis cênica:

Os praticáveis na base da parede servem bem para a luta (páginas 138-149). Kurvenal, quando ferido, caminha para a luz e cai perto de Tristão. Nenhum dos homens de Mark ou Kurvenal deixa a área escura. - O máximo cuidado deve ser tomado na aplicação das sombras criadas pelos personagens na última cena. Isso significa que Mark e Brangânia, de costas para os instrumentos [refletores], tornam-se silhuetas escuras que não projetam qualquer sombra sobre as personagens centrais. Kurvenal caiu na sombra projetada por Tristão. Começando na página 254, a luz continua a desvanecer-se, mergulhando o ambiente em um crepúsculo cada vez mais profundo. A cortina fecha-se em uma imagem calma e uniformemente iluminada, na qual o olho pode distinguir apenas o último toque do sol minguante, que vai suavemente colorir o vestido branco de Isolda. ${ }^{170}$ (APPIA, 1962, p. 205, tradução nossa)

\footnotetext{
169 "Starting with page 236 , the lighting takes on the hues of sunset, then rapidly decreases its intensity during pages 238-242 until, on pages $245-248$, the turbulent action occurs in relative darkness and the audience cannot distinguish its details, while the downstage areas are hit directly by a light which grows redder and redder..."

170 "The platforms at the foot of the wall serve well for the fighting (pages 138-149). Kurvenal, when wounded, steps into the light and falls down close to Tristan. None of or Kurvenal's men leaves the dark area. - The greatest care must be taken in handling the shadows created by the characters in the last scene. This means that Mark and Brangaene, their backs turned toward the spotlight, must become dark silhouettes without throwing any shadow on the two principals. - Kurvenal has fallen into the shadow cast by Tristan. Beginning with page 254, the light
} 
Provocado pelas referências do libreto de Wagner aos conflitos entre noite e dia, Appia efetivamente pensava que se deve dispensar cuidado particular às sombras. Ele acreditava que, no espetáculo de Wagner, a interação entre luz e sombra poderia funcionar como uma espécie de leitmotiv visual: uma vez estabelecido, poderia ser desenvolvido, irradiando-se e impregnando o espetáculo.

Em face disso, o ato de projetar luzes sobre a cena, por mais coloridas, tecnologicamente atraentes, pulsantes, ainda pareceria pouco, sem a atenção devida à qualidade dos volumes da geografia da cena que somente se efetivam através da elaboração precisa das sombras. Vale reiterar que tais ponderações sugerem justificativa para a investigação da sombra e sua contribuição para a cena, o que indica pesquisas específicas, considerando-se os importantes estudos acerca da sombra, já disponíveis. Portanto, a estrita "visibilidade" que apenas ilumine, mesmo maquilada de cor, grafismo, brilho e efeitos especiais, pode se revelar parcial e incompleta na práxis cênica se não incorporar o valor visual da sombra.

Há uma sutileza, incluída na tradução alemã da obra de Appia, que destaca - influenciada pela Teogonia ${ }^{171}$ - a diferença entre Erebus, ou sombra profunda, filho de Caos, deus da escuridão e Nix [Nv́\}], sua irmã gêmea, a bela e sombria personificação da noite que traz o dia. Em Nix, a noite incorpora uma atitude positiva, construtiva, pois representa uma espécie de mensageira que anuncia o dia.

Portanto, para concluir essas observações acerca da obra de Appia cabe reafirmar que sua abordagem da luz como agente ativo da cena inclui a sombra, na sua condição de aspecto definidor da presença e da extensão de um corpo em um ambiente e, portanto, como aspecto estético-poético do seu teatro.

Como provocação, restam algumas perguntas: por que, apesar do seu avançadíssimo idearium, Wagner não levou em conta o projeto visual de Appia e se manteve ligado à cenografia de telões neorrealistas-românticos da empresa dos irmãos Brückner, já citados, em conjunto com os aparatos usados na iluminação teatral de sua época? Como explicar tal contradição, que põe frente à frente,

\footnotetext{
continues to fade, plunging the setting into an ever deeper twilight. The curtain closes on a quiet and uniformly lighted picture in which the eye can distinguish only the last touch of the waning sun which faintly colors Isolde's white dress."

171 Poema de Hesíodo sobre o nascimento dos deuses. Segundo Marilena Chaú (2000, p. 19): A palavra gonia tem sua origem etmológica em duas palavras gregas: do verbo gennao (engendrar, gerar, fazer nascer e crescer) e do substantivo genos (nascimento, gênese, descendência, gênero, espécie). Gonia, portanto, quer dizer: geração, nascimento, a partir da concepção sexual e do parto. Cosmos, como já vimos, quer dizer mundo ordenado e organizado. Assim, a cosmogonia é a narrativa sobre o nascimento e a organização do mundo, a partir de forças geradoras (pai e mãe) divinas. Teogonia é uma palavra composta de gonia e theós, que, em grego, significa as coisas divinas, os seres divinos, os deuses. A teogonia é, portanto, a narrativa da origem dos deuses, a partir de seus pais e antepassados.
} 
o Wagner inovador e revolucionário do drama poético-musical (Wort-tondrama) e da arquitetura teatral, e o conservador sustentado pelos aspectos visuais de um espetáculo que se apoiava visualmente nos mencionados telões pintados? Ainda que não se conheçam respostas para tais indagações há, pelo menos, espaço para apresentá-las.

Como se pode constatar, há questões estreitamente ligadas ao discurso visual que nem sempre estão diretamente ligadas à abordagem do diretor (nem mesmo àquelas do "encenador" brasileiro), mas que precisam contar com o iluminador para reconhecê-las e encaminhá-las como problematização visual para a cena. 